\title{
A PUBLIC SCHOOL VOUCHER DEMONSTRATION: THE FIRST YEAR AT ALUM ROCK TECHNICAL APPENDIX
}

PREPARED FOR THE NATIONAL INSTITUTE OF EDUCATION

DANIEL WEILER, STUDY DIRECTOR WITH THE COLLABORATION OF

PIERCE BARKER WILLIAM S. FURRY

R. GARY BRIDGE SUE A. HAGGART

THEODORE S. DONALDSON ROBERT E. KLITGAARD

ROBERT T. RILEY

R-1495/2-NIE

JUNE 1974 



\section{A PUBLIC SCHOOL VOUCHER DEMONSTRATION: THE FIRST YEAR AT ALUM ROCK TECHNICAL APPENDIX}

PREPARED FOR THE NATIONAL INSTITUTE OF EDUCATION

\section{DANIEL WEILER, STUDY DIRECTOR}

WITH THE COLLABORATION OF

PIERCE BARKER WILLIAM S. FURRY

R. GARY BRIDGE SUE A. HAGGART

THEODORE S. DONALDSON ROBERT E. KLITGAARD

ROBERT T. RILEY

R-1495/2-NIE

JUNE 1974 



\section{PREFACE}

This Technical Appendix is the third of four Rand reports that describe and analyze the workings of an education voucher demonstration during its first year (academic year 1972-73).

The other volumes of the series are:

R-1495-NIE, A Public School Voucher Demonstration: The First Year at Alum Rock, Daniel Weiler, Study Director, June 1974

R-1495/1-NIE, A Public School Voucher Demonstration: The First Year at Alum Rock, Summary and Conclusions, Daniel Weiler, Study Director, June 1974

R-1495/3-NIE, A Public School Voucher Demonstration: The First Year at Alum Rock, Documentary Appendix, Daniel Weiler, Study Director, June 1974

The appendixes in this volume contain additional technical material related to the contents of R-1495-NIE, the main volume of the series, and are numbered to correspond with the section numbers of that report. All four volumes of the study were prepared pursuant to NIE Contract B2C-5326.

The Education Voucher Demonstration is a large-scale educational and social intervention that began in the Alum Rock Union Elementary School District, San Jose, California, in September 1972. First funded by the Office of Economic Opportunity, it is now sponsored by the National Institute of Education.

Since April 1972, Rand has been collecting and analyzing data related to the demonstration. Our work documents events and outcomes in the demonstration; analyzes social, political, economic, and educational impacts of the demonstration; and identifies implications of the voucher concept for federal, state, and local education policies. 



\section{CONTENTS}

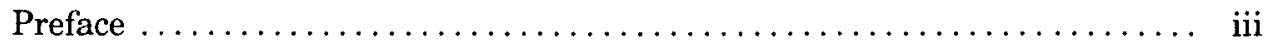

Appendix I. The Use of Comparison Groups.................... 1

Appendix III. The Federal Grant for the Voucher Demonstration........ 6

Appendix IV. The Voucher Financial Information System............ 20

Appendix V-A. Classroom Observation Checklist ............... 25

Appendix V-B. Information Package for Meetings with Mini-school

Faculties in the Spring ............................ 28

Appendix V-C. Educational Costs by School, Mini-school, and Classroom . . 32

Appendix VI-A. Community Opinion Survey ................... 44

Appendix VI-B. Parent/Community Survey ................. 73

Appendix VI-C. Student Transfers $\ldots \ldots \ldots \ldots \ldots \ldots \ldots \ldots \ldots \ldots \ldots$

Appendix VI-D. Sources of Information about Vouchers............. 86

Appendix VII. Demographic Characteristics of Alum Rock Teachers ..... 92

Appendix VIII-A. Methodological Issues in Measuring Student Achievement $\ldots \ldots \ldots \ldots \ldots \ldots \ldots \ldots \ldots \ldots \ldots \ldots \ldots \ldots \ldots \ldots$

Appendix VIII-B. Preliminary Analysis of Achievement Test Scores in Alum Rock Voucher and Nonvoucher Schools, 1972-73........... 105

Appendix VIII-C. Preliminary Analysis of Metropolitan Achievement Test Scores, Voucher and Title I Schools, $1972-73 \ldots \ldots \ldots \ldots \ldots \ldots \ldots$

Appendix VIII-D. Affective Testing . . . . . . . . . . . . . . . 131 



\title{
Appendix I THE USE OF COMPARISON GROUPS
}

\author{
by Pierce Barker
}

Much of the research in the social sciences deals with change. That is especially true in evaluation research and the analysis of social demonstrations, where the objective is to assess the consequences of some intervention. In the most general terms, two issues or questions are involved: (1) Did any change occur? (2) If so, why?

In most cases, the first question is far easier to answer; measurements are made at two points in time, and a decision, usually guided by statistical criteria, is made based on differences between the two measurements on dimensions of interest.

People are usually more interested in the second question, however. That is, one would like to know whether any observed change can be causally linked to the intervention; or, to go to the other extreme, whether the change can be accounted for by factors apart from the intervention. That is usually a matter of degree, of course; i.e., the question properly is how much of any observed change can reliably be attributed to the intervention.

Such measures obviously involve some sort of comparison process, of which Campbell and Stanley (1963) have the following to say:

Basic to scientific evidence ... is the process of comparison, of recording differences, or of contrast. Any appearance of absolute knowledge, or intrinsic knowledge about singular isolated objects, is found to be illusory upon analysis. Securing scientific evidence involves making at least one comparison. For such a comparison to be useful, both sides of the comparison should be made with similar care and precision.

Even assuming that we have met the criteria set out in this dogmatic prescription, however, we are only part way home. That is, it enables us to verify that a change occurred, if it did, but it does nothing to explain why it occurred. At this point the idea of the control (or, better comparison) condition enters the picture. The clearest case of the use of comparison groups occurs in experimentation; and the ideal comparison group is identical to the experimental group in all respects but one, that one being the intervention or manipulation whose effect the experimenter wishès to assess.

It follows that the usefulness of any comparison group is a function of its degree of pretreatment similarity to the group within which the intervention is made. Using the comparison group protects the researcher from having his inferences about the effect of the intervention weakened by alternative explanations-what Campbell and Stanley call "plausible rival hypotheses." If the comparison and experimental groups differ in many respects, any one of which may plausibly explain observed differences between them aside from the fact that the intervention occurred in one and not the other, then the comparison group does not fulfill its intended purpose.

In general, there are two methods of constructing comparison groups: (1) random assignment and (2) matching. The first may be illustrated by the simplest case in which there is only one experimental group and one comparison (here, a nontreatment) group. From the available pool, subjects are assigned to one group or the 
other by a strictly random process. Random assignment ensures that any difference between the two groups on any characteristics will be a chance difference; over all possible random assignments of subjects to groups, the expected value of the difference on any characteristic equals zero. This holds for differences on the dependent variable prior to the treatment, but it also holds for any or all other characteristics on which the subjects may differ and which may be correlated with the dependent variable; this includes unmeasured, unmeasurable, and indeed unknown variables. The result is that, apart from chance departures, the two groups are identical in all respects prior to the treatment or intervention. The purpose of statistical tests of significance is, of course, to allow us to assess the likelihood that any results we get are the result of chance pretreatment differences.

Matching in isolation (i.e., without concurrent randomization) should only occur in circumstances precluding random assignment. The purpose of matching is to deliberately equate the two groups on variables thought to be relevant to the outcome measure at hand, so that preexisting differences on these matching variables cannot be invoked as a rival to the inference that the treatment had an effect. Matching without randomization is in general not recommended, if only because in matching on one set of characteristics, one may easily mismatch on other, perhaps more crucial, dimensions.

It is in theory possible to establish multiple comparison groups, some of which are matched with the experimental group on certain characteristics, some matched on others, and this process may be extended as far as one wishes. Then, if one finds differences between the experimental group and the control groups, a plausible rival hypothesis for one comparison may be ruled out by matching on another.

In large-scale social interventions, randomization is often impossible. On the other hand, one may nevertheless perform valid internal comparisons, given certain conditions; that is, one may seek to compare the results of an overall intervention on subgroups of interest within the total group receiving the intervention. For example, if the overall intervention is realized within the site in different ways, one may in theory compare the results of these diverse realizations. The principal problem here usually results from the fact that individuals getting the different 'treatments' are self-selected; that is, they choose one treatment or another for reasons presumably relevant to the treatments. Take as an example students who choose to participate in a remedial reading program. Given random assignment, one would expect that there would be no significant difference between treatments on initial reading skills. Given self-selection, one would of course expect initial differences: poorer readers are probably more likely to sign up for remedial programs. Moreover, one might well expect to find differing rates of improvement between these groups.

In this situation, where treatment-pretest correlations are not expected to be zero, several strategies exist. One of these would seek to explain the correlation in terms of known group differences; given that the residual correlation approximated zero, we might then be able to make comparisons similar to those in a randomized experiment. A related strategy would examine changes in the size of these correlations over time. Still another might examine differences in regression functions within groups. (See, e.g., Kenny, Cronbach and Furby, 1970.)

Still, the impossibility of random assignment to treatments does not absolutely cripple us. One recourse, apart from the internal comparisons already discussed, is to select nonequivalent groups (in the sense of equivalence implicit in the idea of random assignment). As we have already indicated, establishing and measuring enough such groups will in theory enable us to make inferences as strong as we wish. The key question, however, is of course the degree and kind of lack of equivalence. Note that we are now dealing, not with internal comparisons, i.e., of groups each of 
which received some variety of intervention, but with comparisons of a "project" group with some other "nonproject" group. In the present context, we would compare the "voucher" with a "nonvoucher" site.

Another variant of this type of comparison involves a treatment group and a "reasonably" nonequivalent group. Assume that, on dimensions of interest, we could secure measurements at a number of time points prior to the introduction of the "treatment" to one of the groups, and could moreover continue these parallel measurements for a number of time points subsequent to the application of the "treatment." Then we could look for departures of the response curves from their former trend lines, in an effort to answer at least two questions: (1) are the departures from the previous trends real (i.e., usually, statistically significant); and (2) are they reasonably attributable to the intervention? The simplest case, of course, would be a marked departure in the "treatment" group and a continuation of the former trend in the comparison group.

Clearly, the preceding discussion has done no more than sketch the varieties of alternative approaches to introducing comparison groups into research. The problem here, as always, is to apply the theory in a maximally beneficial way within the circumstantial constraints of a real world problem. Specifically, what are we to say about the voucher demonstration in Alum Rock?

It should be clear that random assignment to the voucher "treatment" at the district level is not worth considering. ${ }^{1}$ This is even more true of what we might consider "treatments"-for example, educational programs with differing emphases -within the district's voucher schools. The basic idea of the voucher after all, is to provide students and their parents with maximally free choice of educational alternatives; the very idea of random assignment is antithetical to this orientation.

Alum Rock is in many respects a special site. If we consider the average SES of the local population, the unusually high degree of migration, and the ethnic mix, it is clear that it would be difficult to locate a "reasonably" nonequivalent comparison district. Assuming that such a district (or, better, districts) could be found, the problems of securing the cooperation of these other districts for what must inevitably be a considerable degree of interruption of their routines, without palpable advantage to them, and of mounting and financing parallel assessment efforts, are formidable.

On the other hand, not all of the schools in Alum Rock chose to participate in the voucher demonstration, so that within the school district, there are voucher and nonvoucher schools. On the reasonable assumption that the district is itself more likely to be homogeneous on most relevant variables than this district would be with other districts that might be selected for comparisons, the nonvoucher schools, while not a random sample of district schools, would seem prima facie reasonable candidates for the status of comparison group.

From the formal viewpoint, it is true that within-district comparisons between

\footnotetext{
${ }^{1}$ Perhaps it is well to mention that the reasons are not logical, but contingent, which means the situation could change. For example, if there had been widespread demand among school districts for a voucher demonstration-if there had been a seller's market-something like random assignment of districts would have been more than possible. In reality, the reverse was true-not an unusual situation when a controversial educational innovation is offered, which calls for major internal changes in the district's system. (See Weiss, 1974.)

If the demand (and financing) were present, we would in fact recommend something like a $2^{\mathrm{n}}$ factorial experimental design with site sampling as the next or near-next step in exploring the voucher idea. On the other hand, it would have been foolhardy to recommend anything nearly so elaborate as a first step, without so much as a test under field conditions: there was no operational evidence that anything like the voucher system could be successfully installed in a field site. Without this minimal knowledge, which could be gained only by installing something like a voucher system and watching what happened, we would have been attempting to walk before we learned to crawl.
} 
the voucher and the nonvoucher schools would probably be rather closely matched on just such variables as were noted above: SES, migration rate, ethnic mix, and so on. However, the fact is that nonvoucher schools in Alum Rock had that status precisely because they did not want to be part of the voucher demonstration; $a$ fortiori, they were unwilling to tolerate the study and analysis activities that the voucher schools barely tolerate as part of the demonstration.

It is also worth noting that the very fact of nonparticipation suggests differences from the voucher schools which, if not explicitly known, are almost certainly relevant to comparisons that might be made. In fact, it is just such suspected and not explicitly identifiable differences that can easily weaken if not invalidate inferences about treatment effects. Suppose, for example, that voucher and nonvoucher schools did differ considerably on the factors of staff morale and cohesion, and degree and style of administrative leadership (a supposition that, in passing, is not unlikely). Strong impressions that such differences, even if not reliably measurable, were nonetheless real and influential, might easily lead to the conclusion that these differences offered a potent rival hypothesis to the proposition that response differences were attributable to the presence of the voucher demonstration. (Note below, however, that an alternative strategy of some potential usefulness may be based upon the fact that new schools are entering the demonstration in the second year.)

Moreover, as mentioned above, the strong likelihood is that not one, but multiple comparisons would be necessary, in view of the very individual nature of the Alum Rock district, not only to strengthen inferences in this demonstration, but to improve the possibilities for generalization from this study. It is the voucher concept itself, and thus a district level of analysis, that is of paramount importance here.

However, this should not obscure the value of internal comparisons, which can of course be made. The Alum Rock voucher schools are not, after all, completely homogeneous; differences in educational alternatives have been planned and implemented within the demonstration site. Schools do differ in leadership style, and the impact of the voucher presence itself upon this factor is of considerable interest. The notion that there exist unassessed treatment-ability (or aptitude or personality) interactions-that, for example, the effects of different teaching methods or curricula may be specific to certain types of students-is seen by some as a likely explanation of the common finding that educational innovations have little or no overall impact (e.g., Anderson, 1970). It may be possible to explore this idea in Alum Rock data.

This is not intended to be a brief against comparison and control in large-scale social intervention research. The entry into the voucher demonstration in its second year of Alum Rock schools which did not participate in the first year affords opportunities for comparison in what we may call a lead-lag design. That is, it should be possible to look at effects of the demonstration over time by comparing second- with first-year schools on the same dimensions. Note that this does not obviate the necessity of identifying and controlling differences between these two classes of schools on other variables; but, by the same logic that applied to inferences between voucher and nonvoucher schools within the district, the likelihood is that differences between first- and second-year schools are less than those between present voucher and nonvoucher schools.

The introduction of suitable comparison groups into future research on the voucher concept is much to be desired, but entails serious considerations beyond the mere decision to proceed with it. For one thing, ample lead time is necessary, so that "suitable" groups may be selected (in the sense of the criteria sketched above); and prior to the choice, of course, sufficient measurement must be done to enable their suitability to be assessed. For another, the cost of additional groups will clearly be 
greater than that for one only; what is involved is in fact something near a duplication of assessment in each such group. Again, this is not to say that it cannot and should not be done, only that there are costs and prerequisites which must be clearly stated and met. It is characteristic of projects of this kind that their period of gestation is relatively long, but once they come to term, they start up almost overnight. ${ }^{2}$ It is hardly necessary to point out that this trend does not promise much by way of lead time.

In many ways, the Alum Rock experience has been very useful for its testimony on the question of comparison groups. For one thing, it is providing a good deal of acute appreciation of the logistics involved in assessment methodology, which will enable us to undertake similar projects on an expanded scale, including the establishment of relevant comparisons, without the necessity of repeating the experiental learning that is inevitably involved in undertakings of this magnitude.

The question, then, is not one of the usefulness of comparison groups in the abstract, but of their availability and relevance in the current context. Given the circumstances of the establishment of the present demonstration, a clearcut comparison group was not a viable possibility. This may well not be true of future projects, but we are now concerned with Alum Rock. Inclusion of relevant groups would inevitably have delayed the establishment of the Alum Rock demonstration, and at the time this was not feasible.

However, it has been one purpose of this brief review to indicate that the absence of formal extramural comparison groups is not necessarily a fatal disability; nor would their inclusion have been a blanket assurance that they would have been useful. The particular circumstances that form the context of a specific study are of paramount importance, not the researcher's professional dogma.

\footnotetext{
${ }^{2}$ The final go-ahead for Alum Rock came in April 1972; the demonstration got under way in September, after a summer of intensive preparation. For a project of this size and complexity, this is tantamount to no lead time at all; but if a second site is selected, the pattern seems likely to be repeated.
}

\section{REFERENCES}

Anderson, G. J., "Effects of Classroom Social Climate on Individual Learning," $A m$. Ed. Res. J., Vol. 7, 1970, pp. 135-151.

Campbell, D. T., and J. C. Stanley, "Experimental and Quasi-Experimental Designs for Research on Teaching," in N. L. Gage (ed.), Handbook of Research on Teaching, Rand McNally and Co., Chicago, 1963.

Cronbach, L. J., and L. Furby, "How We Should Measure 'Change'-or Should We?" Psychological Bulletin, 1970, Vol. 74, No. 1, pp. 68-80.

Kenny, D. A., "Temporal Changes in Treatment-Effect Correlations: A Quasi-Experimental Model for Panel Studies" (in press).

Weiss, E. H., "The Missing Variable in Input-Output Studies," Planning and Change, Vol. 4, 1974, pp. 203-210. 


\title{
Appendix III \\ THE FEDERAL GRANT FOR THE VOUCHER DEMONSTRATION
}

\author{
by Sue A. Haggart
}

\begin{abstract}
Alum Rock's 1972-73 income from federal sources, both direct federal funds and federal funds channeled through the state machinery, almost doubled over the previous year (see Table III-1). The voucher-related funds shifted from less than 0.5 percent of total 1971-72 funds from federal sources to about 50 percent for 1972-73. State and local income also increased, but made up about the same percentages of district income. Basic equalization aid from the state, however, increased from $\$ 6.3$ to $\$ 7.0$ million but decreased as a percentage of total income. The total 1972-73 voucher demonstration funds represent about 9 percent of the adjusted district income of $\$ 17,910,624$. Another way of assessing the impact of the voucher demonstration is to look at the budget's Current Expenses Total. This total excludes Transportation, Food Services, Community Services, and Capital Outlay; for 1972-73 it was $\$ 15,672,282$. The voucher funding of $\$ 1,585,756$ is approximately 10 percent of Total Current Expenses.

The percentage distribution of funds by source for the voucher schools and the nonvoucher schools provides another picture of the impact of the voucher grant (Table III-2). On the average, the compensatory voucher funds accounted for 25.9 percent of the income of voucher schools. For the Title I schools, the average income from Title I was 32.9 percent.
\end{abstract}

\section{NATURE OF THE FEDERAL GRANT}

The allocation and earmarking of funds for the elementary education voucher demonstration in Alum Rock resulted from bargaining between local district officials and officials from OEO, and later from NIE. A summary of funding as a result of agreements to date is shown in Table III-3 in the format prescribed by the Office of Management and Budget. Details by cost category are shown in Table III-4. Most of the increases took place in Cost Categories 1.1 Salaries and Wages, 1.3 Consultants and Professional Services, and 2.6 Other Direct Costs. Agreements of a substantive nature were spelled out in subcategories of these broad categories and were stated, in some cases, as special conditions governing the use of funds. These increases were covered in two negotiated additional grants. The data in Tables III-3 and III-4 show the combined funding for the education voucher demonstration through June 30 , 1975 as of March 14, 1973.

A breakdown of the 1972-73 and 1973-74 budgets, shown in Table III-5, provides information about the activities in support of the voucher demonstration. (The expenditure categories for 1973-74 were developed by the Sequoia Institute, and the 1972-73 grant and the prior grant funds were allocated to the same expenditure categories.) A description of each category provides insights into the nature of the federal grant. A comparison of the first and second year grants helps to understand the operation of the voucher demonstration. 
Table III-1

ALUM ROCK UNION ELEMENTARY SCHOOL DISTRICT: FINAL INCOME BUDGET, 1971-72, AND PROJECTED INCOME BUDGET, 1972-73

\begin{tabular}{|c|c|c|c|c|}
\hline Income Source & $\begin{array}{c}1971-72 \\
\text { Funds }\end{array}$ & $\begin{array}{l}\text { Percent } \\
\text { of } \\
\text { Budget }\end{array}$ & $\begin{array}{l}1972-73 \\
\text { Fund s }{ }^{a}\end{array}$ & $\begin{array}{l}\text { Percent } \\
\text { of } \\
\text { Budget }\end{array}$ \\
\hline Net balance & 386,904 & 2.7 & 251,592 & 1.5 \\
\hline $\begin{array}{l}\text { Federal } \\
\text { PL } 874 \\
\text { PL } 88 \text { 452 OEO } \\
\text { Title I ESEA } \\
\text { Title I Migrant } \\
\text { Title II ESEA } \\
\text { Title III NDEA } \\
\text { Title VII ESEA } \\
\text { HUD Model Citles } \\
\text { Calif. Criminal Justice } \\
\text { Preschool Ed. Aid }\end{array}$ & $\begin{array}{r}60,000 \\
52,765 \\
885,51.7 \\
28,605 \\
27,767 \\
2,671 \\
104,224 \\
--- \\
--- \\
98,230 \\
1259779\end{array}$ & 8.8 & $\begin{array}{r}70,000 \\
933,170^{\mathrm{b}} \\
802,202 \\
-- \\
40,000 \\
3,943 \\
119,596 \\
155,000 \\
87,532 \\
142,582 \\
354,025\end{array}$ & 13.6 \\
\hline State & & & & \\
\hline $\begin{array}{l}\text { Basic Equal. Aid } \\
\text { Educ. handicapped } \\
\text { Mentally gifted } \\
\text { Mentally retarded } \\
\text { Physically handicapped } \\
\text { Sev. mentally retarded } \\
\text { Transport. handicapped }\end{array}$ & $\begin{array}{r}6,334,260 \\
159,500 \\
13,460 \\
100,618 \\
289,900 \\
47,477 \\
27,230 \\
638,185\end{array}$ & 44.3 & $\begin{array}{r}7,024,182 \\
278,195 \\
27,740 \\
98,520 \\
309,515 \\
45,420 \\
43,000 \\
802,390\end{array}$ & 40.7 \\
\hline $\begin{array}{l}\text { Allow. transportation } \\
\text { Elem. school reading } \\
\text { County income } \\
\text { Special Physical Education }\end{array}$ & $\begin{array}{r}111,946 \\
96,530 \\
7,427 \\
-\cdots \\
215,903\end{array}$ & 1.5 & $\begin{array}{r}103,000 \\
96,530 \\
12,000 \\
11,625 \\
223,155\end{array}$ & 1.3 \\
\hline $\begin{array}{l}\text { Local } \\
\text { District taxes } \\
\text { Areawide taxes } \\
\text { Other local } \\
\text { Other tuition }\end{array}$ & $\begin{array}{r}3,900,381 \\
1,505,918 \\
43,158 \\
18,000 \\
5,467,457\end{array}$ & 38.2 & $\begin{array}{r}4,658,143 \\
1,884,415 \\
143,902 \\
\quad 12,000 \\
6,602,694\end{array}$ & 38.3 \\
\hline Total & $\$ 14,302,488$ & 100.0 & $\$ 17,258,038$ & 100.0 \\
\hline
\end{tabular}

SOURCE: The Final Income and Expenditure Budget of the Alum Rock Union Elementary School District.

${ }^{a}$ Projected income as of July 31, 1972.

boes not include total voucher demonstration grant. The 1972-73 combined grant was $\$ 1,585,756$. 
Table III-2

BUDGETED EXPENDITURES PER REGULAR STUDENT AND SOURCE OF FUNDS FOR VOUCHER SCHOOLS AND NONVOUCHER SCHOOLS, 1972-73

\begin{tabular}{|c|c|c|c|c|c|c|c|c|}
\hline \multirow[b]{2}{*}{ School } & \multirow[b]{2}{*}{$\begin{array}{l}\text { Number of } \\
\text { Students }\end{array}$} & \multirow[b]{2}{*}{$\begin{array}{l}\text { Budget } \$ \\
\text { Per Student }\end{array}$} & \multirow[b]{2}{*}{$\begin{array}{r}\text { Estimated } \\
\text { Budget } \$\end{array}$} & \multicolumn{5}{|c|}{$\begin{array}{l}\text { Source of Funds } \\
\text { (Percentage Distribution) }\end{array}$} \\
\hline & & & & $111 / 141^{b}$ & $\begin{array}{l}\text { Model } \\
\text { Cities }\end{array}$ & $\begin{array}{l}\text { Comp. } \\
\text { voucher }\end{array}$ & Title I & Other \\
\hline Arbuckle & 536 & 816 & 437,376 & 65.9 & -- & -- & 30.2 & 3.9 \\
\hline Casse11 ${ }^{\mathrm{C}}$ & 671 & 704 & 472,384 & 74.3 & 1.9 & 23.8 & -- & -- \\
\hline Coniff & 372 & 869 & 323,268 & 63.0 & -- & -- & -- & $37.0^{\mathrm{d}}$ \\
\hline Cureton & 487 & 552 & 268,824 & 99.4 & 0.6 & -- & -- & -- \\
\hline Dorsa & 634 & 563 & 356,942 & 95.5 & 4.5 & -- & -- & -- \\
\hline $\operatorname{Goss}^{c}$ & 708 & 682 & 482,856 & 67.2 & 2.8 & 26.2 & -- & 3.8 \\
\hline Hubbard & 522 & 782 & 408,204 & 68.3 & $(e)$ & -- & 31.7 & -- \\
\hline Linda Vista & 702 & 544 & 381,888 & 96.3 & - & -- & -- & 3.7 \\
\hline Lyndale & 612 & 452 & 276,624 & 99.4 & 0.6 & - & -- & -- \\
\hline Mayfair & 684 & 724 & 495,216 & 66.4 & -- & -- & 33.6 & -- \\
\hline McCollam ${ }^{c}$ & 584 & 669 & 390,696 & 70.5 & 0.4 & 29.1 & -- & -- \\
\hline Meyer $^{c}$ & 781 & 662 & 517,022 & 68.8 & 3.9 & 24.0 & -- & 3.3 \\
\hline Miller & 458 & 898 & 411,284 & 70.9 & 2.8 & 26.3 & -- & -- \\
\hline Mt. Hamilton & 8 & 1441 & 11,520 & 100.0 & -- & - & -- & -- \\
\hline Painter & 295 & 654 & 192,930 & 99.2 & 0.8 & -- & -- & -- \\
\hline Rogers & 582 & 503 & 292,746 & 99.5 & 0.5 & -- & -- & -- \\
\hline Ryan & 661 & 552 & 364,872 & 100.0 & -- & -- & - & -- \\
\hline San Antonio & 355 & 915 & 324,825 & 68.1 & -- & - & 31.9 & -- \\
\hline Shields & 641 & 463 & 296,783 & 99.5 & 0.5 & -- & -- & -- \\
\hline Slonaker & 591 & 722 & 426,702 & 62.2 & (e) & -- & 33.3 & 4.5 \\
\hline Fisher & 1046 & 665 & 695,590 & 94.6 & 3.1 & -- & -- & 2.3 \\
\hline George & 631 & 670 & 422,770 & 96.7 & - & -- & - & 3.3 \\
\hline Mathson & 651 & 893 & 581,343 & 91.8 & 2.6 & -- & -- & 5.6 \\
\hline $\mathrm{Pala}$ & 601 & 859 & 516,259 & 79.4 & -- & 17.8 & -- & 2.8 \\
\hline Sheppard & 991 & 716 & 709,556 & 96.1 & 1.8 & -- & -- & 2.1 \\
\hline
\end{tabular}

${ }^{a}$ Special education students and funds are excluded. Enrollment figures and distribution data are from unpublished district sources.

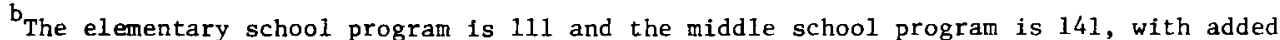
programs 142-151 for middle subjects such as art, math, science, industrial arts, etc.

c1972-73 voucher schools.

Title VII, Bilingual Education.

Less than 0.5 .

Table III-3

VOUCHER DEMONSTRATION BUDGET SUMMARY, 1971-75

\begin{tabular}{|c|c|c|c|c|c|}
\hline Cost Category & $1971-72$ & $1972-73$ & $1973-74$ & $1974-75$ & Total \\
\hline $\begin{array}{l}\text { 1.1 Salaries and wages } \\
1.2 \text { Fringe benefits } \\
1.3 \text { Consultant and } \\
\text { professional services } \\
2.1 \text { Travel } \\
2.2 \text { Space costs and rentals } \\
2.3 \text { Consumable supplies } \\
2.4 \text { Lease and purchase of } \\
\text { equipment } \\
2.5 \text { Investment capital } \\
2.6 \text { Other direct costs } \\
3.0 \text { Indirect costs } \\
\text { Year total } \\
\text { Cumulative total }\end{array}$ & $\begin{array}{c}10,132 \\
2,794 \\
12,223 \\
412 \\
-759 \\
1,642 \\
2,418 \\
3,498 \\
33,878 \\
33,878\end{array}$ & $\begin{array}{r}188,750 \\
31,500 \\
218,190 \\
7,000 \\
9,200 \\
5,000 \\
30,000 \\
--- \\
1,039,153 \\
56,963 \\
1,585,756 \\
1,619,634\end{array}$ & $\begin{array}{r}271,863 \\
49,822 \\
286,962 \\
15,000 \\
54,400 \\
10,000 \\
20,500 \\
-- \\
2,111,450 \\
104,871 \\
2,924,868 \\
4,544,502\end{array}$ & $\begin{array}{r}266,387 \\
47,950 \\
190,148 \\
15,000 \\
54,400 \\
10,500 \\
21,000 \\
-- \\
1,679,450 \\
85,851 \\
\\
2,370,686 \\
6,915,188\end{array}$ & $\begin{array}{r}737,132 \\
132,066 \\
707,523 \\
37,412 \\
118,000 \\
26,259 \\
73,142 \\
-- \\
4,832,471 \\
251,183 \\
6,915,188 \\
6,915,188\end{array}$ \\
\hline
\end{tabular}

SOURCE: Federal grant data as of March 1973.

NOTE: Dates are April 1 through June 30 for each column. 
Table III-4

ALUM ROCK VOUCHER BUDGET: COMBINED FUNDING AS OF MARCH 1973

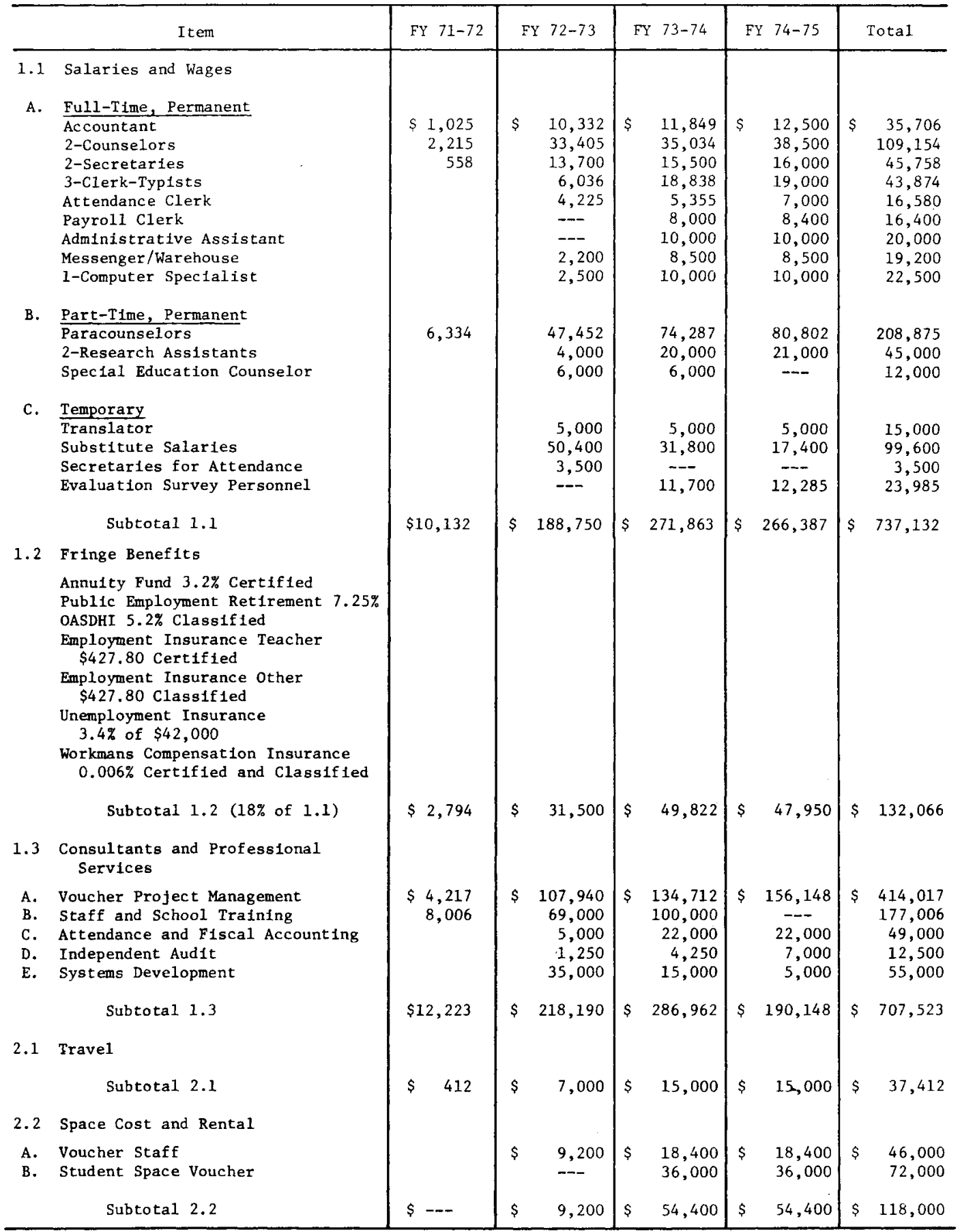


Table III-4 (continued)

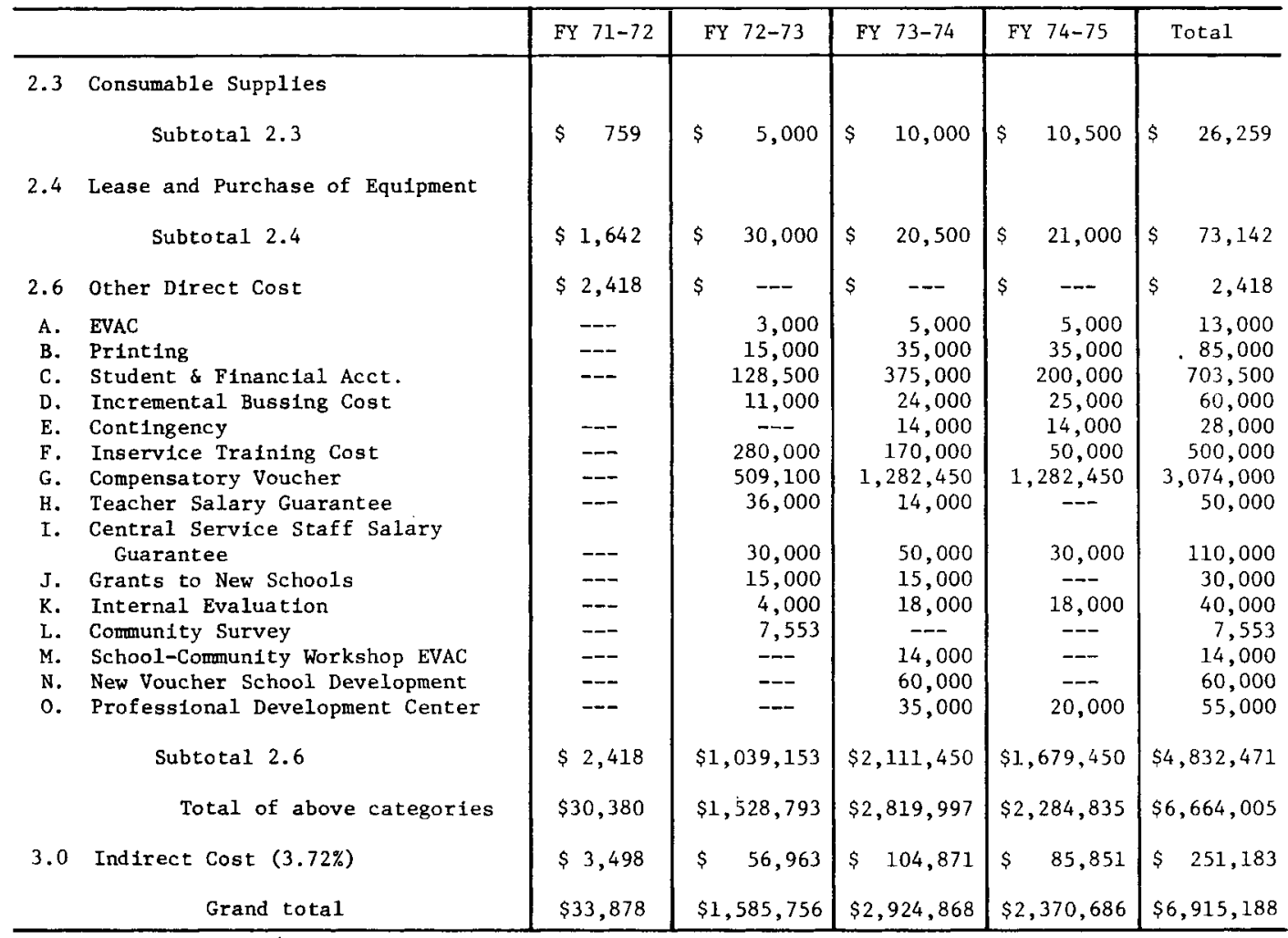

SOURCE: Letter (including budget) to Superintendent Jefferds from Denis Doyle of oEO, March 16,1973 .

Table III-5

COMPARISON OF EXPENDTTURE CATEGORIES, FIRST AND SECOND YEAR GRANTS

\begin{tabular}{l|r|r|r}
\hline \multicolumn{1}{c|}{ Expenditure Category } & $\begin{array}{r}\text { Prior } \\
\text { Grants, } \\
1971-72\end{array}$ & $\begin{array}{r}\text { First Year } \\
\text { Grants, } \\
1972-73\end{array}$ & $\begin{array}{r}\text { Second Year } \\
\text { Grants, } \\
1973-74\end{array}$ \\
\hline District administrative costs & 4,001 & 191,683 & 289,004 \\
Parent counseling staff & 8,549 & 91,857 & 180,321 \\
Evaluation & - & 8,000 & 49,700 \\
Fringe benefits & 2,794 & 31,500 & 49,822 \\
Inservice training and management & 12,223 & 399,400 & 336,800 \\
Travel & 412 & 7,000 & 15,000 \\
Space cost, staff & -- & 9,200 & 18,400 \\
Consumable supplies & 759 & 5,000 & 10,000 \\
Lease and purchase of equipment & 1,642 & 30,000 & 20,500 \\
EVAC and parent involvement & -- & 10,553 & 19,000 \\
Printing & -- & 15,000 & 35,000 \\
Bussing & -- & 11,000 & 24,000 \\
Compensatory voucher & -- & 509,100 & $1,282,450$ \\
Student and financial accounting & -- & 128,500 & 375,000 \\
Reserve funds & -- & 81,000 & 79,000 \\
Student space voucher & -- & $-5,-000$ \\
Indirect costs (3.72\%) & 3,498 & 56,963 & 104,871 \\
Total & 33,878 & $1,585,756$ & $2,924,868$ \\
\hline
\end{tabular}

SOURCE: Federal grant data, March 1973. Sequoia Institute breakdown of the federal grant for $1973-74$ is used for the 1972-73 and 1971-72 grants. 
The budgeted amounts in the categories Travel and Consumable Supplies support the activities of the voucher staff and the central district administrative staff involved with the voucher demonstration. The category of Lease and Purchase of Equipmentincludes first year funds of $\$ 15,000$ for a one-time expenditure to provide a pool of trailer classroom space. The remainder of this category provides office equipment, furniture, and leased trailer space for the voucher staff. The Space Costs and Rental covers the space the voucher staff rented from the district at a cost of $\$ 9,200$ for the first year and $\$ 18,400$ (to house a larger staff) for the second year.

The Student Space Voucherfund was set up for the second year to provide a pool that could be tapped by schools in need of additional seating capacity. It could not be used by schools with a stable or declining enrollment. It serves as a space market mechanism. The Student Space Voucher of $\$ 36,000$ for $1973-74$ is calculated at $\$ 4$ per student times the 9,000 students in the demonstration. This space voucher was added by the federal agency after the one-time provision for trailer classroom space, which, in turn, had been the response to the district's inability to assure an excess capacity of 10 percent in seating space in the voucher schools.

District Administrative Costs, Parent Counseling Staff, EVAC and Parent Involvement cover salaries and wages for these activities. Fringe Benefits are tied to salaries and wages of the staff involved. The Indirect Costs category includes the budgeted amount for the portion of time the central district staff spent on voucher demonstration activities. Evaluation covers the operational costs of the internal evaluation of the voucher demonstration.

Printing covers the cost of printing the informational material about the voucher demonstration and its mini-school programs for distribution to the parents. Increases are attributable to the increased size of the demonstration. Bussing is in the nature of a reserve fund to cover anticipated expenses in transporting students who enroll in mini-schools outside their regular attendance area. The increase is also attributable to the expanded size of the demonstration.

Inservice Training and Management covers the school and staff training conducted by HRC (Center for Human Resources and Organizational Development), substitute salaries for teacher release time, and the activities of the Professional Development Center in 1973-74. HRC provides management training for the staff of both the central administrative office and the school site. In the first grant, $\$ 69,000$ was budgeted; in the second year, $\$ 100,000$. (HRC records do not permit the allocation of these amounts to school site activities as opposed to central administrative staff activities. For this reason the HRC-budgeted amounts are maintained as a separate line item in the later analysis of the school and administrative costs of the voucher demonstration.)

The initial grant provided $\$ 30,000$ to each voucher school for inservice training of teachers. These funds were used almost exclusively to pay teachers for planning work undertaken during the summer or at other times when teachers would not be working on their regular assignments. A March supplement provided planning money for schools entering the demonstration during the second year. Salaries for substitute teachers were provided for the six voucher schools in a December 1972 supplemental grant and for the new schools entering the demonstration in a March 1973 supplemental grant.

The Professional Development Center budget of $\$ 35,000$ was provided for the second year of the demonstration to support a new program initiated by the superintendent. The Center, with a committee of teachers as part of its management, will assist teachers in identifying and sharing innovative instructional ideas. Some of the substitute salaries will be used to provide release time for teachers in the demonstration. 
Compensatory Voucher represents the amount budgeted to provide a compensatory voucher for each student eligible for the free lunch program. Its value in the first year was $\$ 237.77$ for elementary and $\$ 301.55$ for middle level students. The $1972-73$ compensatory voucher fund total was $\$ 509,100$ ( $\$ 442,000$ provided in the initial grant and $\$ 67,100$ in a supplemental grant). (The $\$ 67,100$ grant action was first carried as $\$ 67,010$ but was changed to $\$ 67,100$ in later budget documentation.) The value of the compensatory voucher in the second year of the demonstration is a flat $\$ 275$ for all eligible students regardless of grade level. Those students also receiving allocations from ESEA Title I are to receive a "discounted" compensatory voucher of $\$ 90$. The compensatory voucher fund for the second year is $\$ 1,282,450$.

The monies budgeted for Student and Financial Accounting cover the expenses associated with school-site administration and the operation of systems to track and account for the flow of students and dollars within the mini-schools of the voucher demonstration. The actual development of the student attendance system and the income/outgo budgeting and accounting system was covered in the staffing costs of district administration and voucher administration.

The expenditure category Reserve Funds has three separate funding arrangements embodied in its rather uninformative title. One is fairly simple; it sets aside $\$ 15,000$ for each of the first two years of the voucher demonstration to assist in the development of community-initiated school alternatives. The title of this fund is "Grants to New Schools." Monies in this fund are not to be spent by existing schools in the Alum Rock School District that are potential entrants into the voucher demonstration. (The development of programs in the Alum Rock public schools was considered as a general voucher demonstration activity. The second-year grant provided a total of $\$ 60,000$ in separate grants of $\$ 10,000$ for each school wishing to enter the demonstration in September 1974.)

The other two funding arrangements under Reserve Funds involve salary guarantees. The Teacher Salary Guarantee fund is $\$ 36,000$ for $1972-73$ and $\$ 14,000$ for the second year of the demonstration. The district's April 1972 proposal to OEO promised full protection of tenure and seniority for participating certified employees. Detailed procedures were established to cover the possible displacement of a teacher from a mini-school with a declining enrollment. In the first year this fund was not needed; the funds can be carried over to the second year. The 1973-74 increment of $\$ 14,000$ due to the increased size of the demonstration, along with the carryover of $\$ 36,000$, provides a reserve fund of $\$ 50,000$ for the teacher salary guarantee.

The third (and final) funding arrangement under Reserve Funds involves a salary guarantee for central district staff who provide central support services to the individual schools of Alum Rock. The contingency fund for Central Service Staff Salary Guarantee was set up essentially to protect the central district against a marked decrease in the demand for central services. The fund size in the 1972-73 grant was $\$ 30,000$ (about two-thirds of which was used); in 1973-74 it was increased to $\$ 50,000$ "to offset the greater possibility of salary loss and/or job dislocation" in the larger demonstration.

This mechanism merits additional discussion. At the suggestion of OEO, the district sought to identify central services that could be purchased at the discretion of the individual schools or mini-schools. The district agreed to the "voucherizing" of three central services: psychological services, curriculum coordination, and audiovisual services. In voucherizing a service, the total cost of providing the service is divided by the total number of students to obtain a voucherized factor, which is then used in allocating the cost of that service or in buying it. Curriculum coordination, however, was not voucherized. For the second year, inservice training, which had 
been a lump sum for each voucher school, was voucherized on a per student basis ( $\$ 50$ for the first year and $\$ 10$ for the second year of a school's participation). Schools and mini-schools then could have the option of buying these services as needed. But the district wanted insurance against the schools not buying from the central office.

Under the voucherizing of these services, an amount equivalent to the dollars used to support the furnishing of these three central services to each school would become part of the basic voucher income allocated to the school. This school-site income, in effect, became discretionary income for the school; these services could be purchased from the district or from an outside supplier-all or part. If the schools and mini-schools opted not to buy these central services, the district could lose money by not having a market for the services it was prepared to provide. Based on past experience, it was estimated that the six voucher schools could be provided with the three services for a cost of $\$ 70,000$. It was agreed that the federal agency would set up a contingency fund to offset a maximum of $\$ 30,000$ of this potential loss. (In actual practice, the superintendent required that each school commit itself to the purchase of an amount of outside services that would not exceed $\$ 30,000$.)

\section{RESTRICTIONS, SPECIAL CONDITIONS, AND SUPPLEMENTAL GRANTS}

Many of the restrictions and special conditions were related to federal control and monitoring of the voucher demonstration monies; those of interest here dealt with specific provisions of the demonstration, such as the development of a per pupil accounting system and school-level income/outgo budgeting. Supplemental grants covered both new activities not included in the initial grant and the increased cost of planned activities.

\section{Restrictions and Special Conditions}

Restrictions were placed on the total funds that could be spent during the period prior to June 30,1973. As of December 2, 1973 only $\$ 1,299,407$ of the combined grant and supplemental grants could be used; on March 14, 1973 the restriction was that only $\$ 1,585,756$ could be used through June 30 . Unused funds from prior fiscal years and prior grants could be used for the purposes of furthering the grant and the voucher experiment. Unused contingency funds for Compensatory Vouchers, Teacher Salary Guarantee, Central Staff Salary Guarantee and Grants to New Schools remain available but only within these categories.

A continuing condition of the grant stated that "a complete per pupil budgeting system and operation which contains mini-school income based upon pupil attendance, and the reporting of complete income/outgo budgets at mini-school level, must be developed for and used in the 1973-1974 academic year." Additional funds were provided to obtain technical assistance for its development. The income/outgo budgeting system and its reports are described later.

Another condition concerned classroom space; the grantee was to develop and implement a plan "to guarantee significant excess pupil capacity among the schools participating in the voucher experiment, if the grantee continues in the voucher experiment in academic year 1973-1974." This condition was not satisfied and a supplemental grant provided a one-time allowance for trailer classroom space. (In the March 1973 grant, a Student Space Voucher Fund was set up. This provides a "space voucher" of $\$ 4$ per participating student. These vouchers are pooled and redistributed as additional space needs for program expansion arise.) 
Restrictions were placed on the spending of funds in several budget categories; the Inservice Training Cost could not be increased by any internal budget adjustment and the Compensatory Voucher total could not be adjusted. The funds for the incremental bussing and planning grants to new schools could be utilized with prior written permission, based on written documentation of need and justification for the expense for the district.

The same restriction was also placed on the funds in Student and Financial Accounting. This applied to the allocation of $\$ 15,000$ per school in the initial grant and to increases in this fund as a result of supplemental grants. The district was also to provide a detailed description of how the $\$ 15,000$ allocated to each voucher school (category 2.6E) to provide additional administrative assistance was being used.

As a condition of the initial grant, the district was also to develop alternative plans for the second and third year of the demonstration with one of the options based on the passage of enabling legislation to allow expansion to a full voucher model involving additional public, private and/or parochial schools, and another option based on a phaseout of the existing internal voucher model involving the six voucher schools. (The second and third year budget data apply to an expansion of the demonstration to include seven newly entering voucher schools in the 1973-74 school year.)

\section{Supplemental Grants}

As shown in Table III-6, the major portion of the supplemental grants covered the increased cost of activities related to the administration of the voucher demonstration and to inservice training. Several new items were included in the first supplement, but for the most part the increases occurred in those categories which were originally understated. An attendance clerk was added to the central staff because of the increased pupil accounting workload that resulted from the introduction of a second parallel pupil accounting system. Some additional funds were added to continue and upgrade the existing system during the transition. Funds were provided for the certified audit required by the special conditions of the voucher demonstration grant. Salaries for substitute teachers had been omitted in the earlier budget. These monies were necessary to provide teacher release time for the HRC inservice work previously budgeted. Additional funds were provided for a part-time research assistant in the district's internal evaluation of the voucher demonstration.

In the area of increased cost of activities, the compensatory voucher fund was supplemented by $\$ 67,000$ to reflect the more accurate estimate of the number of students eligible for the compensatory voucher. As discussed, a one-time cost of trailer classroom space was included in the first supplement. The contingency fund for bussing was increased by $\$ 1,000$ in the first supplement. The other major item in the first supplement was an adjustment of $\$ 30,000$ in indirect cost (overhead) for an underestimate of excess administrative load due to program implementation.

The initial grant provided $\$ 15,000$ for each voucher school for school-site administrative assistance; this was increased by $\$ 3,000$ per school in the first supplement and by a total of $\$ 20,500$ in the second supplement. As a result of these increases, the budgets for the second and third year of the demonstration are based on a decreasing allowance for school-site administrative assistance. The allowance is $\$ 25,000$ for the first year a school participates as a voucher school and then $\$ 20,000$ for the second year and $\$ 10,000$ for the third year. If the principal wishes to maintain the initial higher level of effort, compensatory voucher funds and other voucher funds allocated to the school have to be used to augment centralized funding.

In the first year of the demonstration each voucher school received a flat grant 
Table III-6

BREAKDOWN OF SUPPLEMENTAL FEDERAL GRANTS

FOR 1972-73 SCHOOL YEAR

(In $\$$ thousand)

\begin{tabular}{|c|c|c|c|c|}
\hline Area of Support & $\begin{array}{c}\text { Initial } \\
\text { Grant, } \\
4 / 72\end{array}$ & $\begin{array}{l}\text { Second } \\
\text { Grant, } \\
12 / 72\end{array}$ & $\begin{array}{c}\text { Third } \\
\text { Grant, } \\
3 / 73\end{array}$ & Total \\
\hline Central administration & 238.7 & 57.5 & 137.2 & 433.4 \\
\hline HRC training & 50.0 & -- & 19.0 & 69.0 \\
\hline $\begin{array}{l}\text { Indirect school-site support } \\
\text { Administration }\end{array}$ & 90.0 & 18.0 & 20.5 & 128.5 \\
\hline Inservice for teachers & 180.0 & -- & 100.0 & 280.0 \\
\hline Substitute teacher & -- & 15.3 & 43.5 & 58.8 \\
\hline $\begin{array}{l}\text { Bussing } \\
\text { Subtotal }\end{array}$ & $\frac{10.0}{280.0}$ & $\frac{1.0}{34.3}$ & $\frac{--}{164.0}$ & $\frac{11.0}{478.3}$ \\
\hline Direct school-site support & & & & \\
\hline Compensatory vouchers & 442.1 & 67.0 & -- & 509.1 \\
\hline Classroom space & $\ldots$ & 15.0 & -- & 15.0 \\
\hline Subtotal & $\overline{442.1}$ & $\overline{82.0}$ & - & $\overline{524.1}$ \\
\hline Teacher salary guarantee & 36.0 & -- & -- & 36.0 \\
\hline Central staff salary guarantee & 30.0 & -- & -- & 30.0 \\
\hline Grants to new schools--community & 15.0 & -- & -- & 15.0 \\
\hline Total, a11 areas & $1,091.8$ & 173.8 & 320.2 & $1,585.8$ \\
\hline
\end{tabular}

SOURCE: Various OEO budget documentation as of March 1973.

of $\$ 30,000$ for teacher inservice training. Some of these funds were used by the initial voucher schools at the end of the 1971-72 school year as they were preparing for the following year. In the same manner the supplement of $\$ 100,000$ covers some of the activities of the expansion schools before July 1973 . Thus, the amount of $\$ 280,000$ for inservice training in the 1972-73 budget covered the $\$ 30,000$ allowance for each of the schools and $\$ 100,000$ for the expansion voucher schools inservice training before the opening of the 1973-74 school year.

In the second supplemental grant increases in several line items reflect the additional effort needed to develop the necessary management systems and to manage the demonstration. Specifically, the cost of a systems analyst, an administrative assistant, an attendance secretary, programmers and computer support was covered for the part of the school year that remained. Approximately $\$ 60,000$ of the $\$ 320,000$ supplemental grant was for this purpose.

The initial grant had underestimated the general administrative impact of the voucher demonstration, but not by much-less than an additional 10 percent of the initial grant was required. The underestimate of the effort and time required to develop and install the management support systems was to be expected and it is doubtful that more money could have effectively reduced the development time.

\section{DISTRIBUTION OF VOUCHER DEMONSTRATION FUNDS}

The distribution of funds between the demonstration's administrative activities and the voucher schools provides the necessary fiscal context for discussing the 
budgeting changes brought about by the voucher concept and the school-level impact of the voucher funds. Delineating the fiscal context also sheds some light on the interesting question of start-up versus continuation costs for the demonstration as a whole. The distribution, shown in Fig. III-1, includes the estimated grant for 1973-74 because of the change in the distribution of funds between direct and indirect school-site support as the size of the demonstration increased.

The administration of the voucher demonstration includes the activities of the Sequoia Institute for voucher project management, the added workload of the central district staff, the additional staff of the central district office, additional operating expenses (printing, travel, supplies) at the district level, and the cost of HRC training activities. The Professional Development Center of the second year is considered as an administrative activity. The salary guarantee funds for teachers and central services staff and the planning grants for both Alum Rock schools and community-initiated schools are grouped together in the administration subcategory of contingency funding.

Direct school-site support covers the compensatory voucher funds for each minischool, temporary classroom space (trailers), and the student space voucher fund. Indirect school-site support includes the allocation of funds for administrative assistance to the schools, the allowance for incremental bussing, and the cost of inservice training and substitute teacher salaries.

For the first year, the demonstration included six voucher schools and almost 4000 students; the direct and indirect support of these six schools accounted for about 63 percent of the total funds, split about evenly between direct and indirect
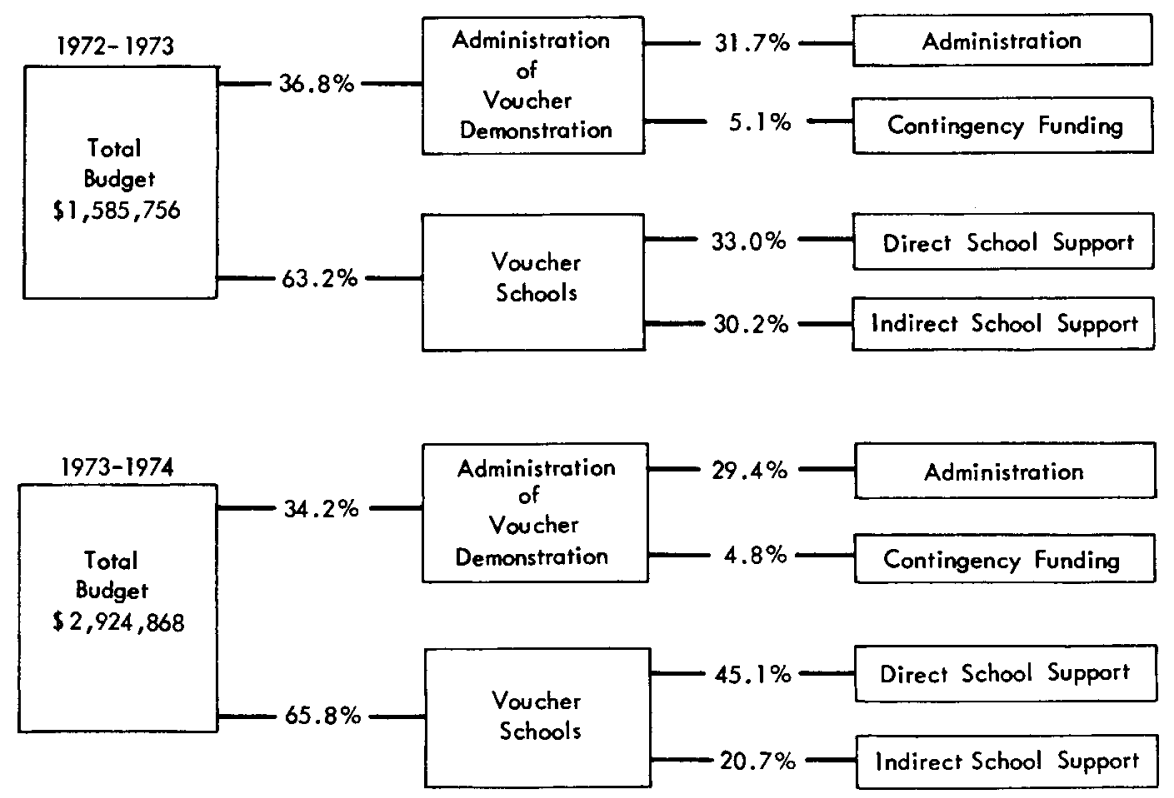

Fig. III-1-Flow of funds to administration of the voucher demonstration and to the school sites 
support. When the demonstration expanded to thirteen schools and approximately 9000 students, the distribution of funds to direct and indirect school support increased only slightly. But the direct support of the schools, mostly the compensatory voucher, increased to 45 percent of the total grant and was more than twice the funds allocated to indirect school support.

The funds for the second year of the demonstration were almost twice those of the first year-a not unexpected occurrence, since the demonstration had almost doubled in size (Table III-7). The interesting question, however, concerns the absence of an expected decrease after the start-up activities were over and the demonstration had entered a more operational phase.

The answer appears to be that the voucher demonstration in the 1973-74 school year is still in the start-up phase; the seven new voucher schools, according to the funding support allocation rules, are in the same phase as the six original voucher schools were in the first year of the demonstration. They have, for example, the higher allowances for school-site administrative assistance and for inservice training.

Delineation of start-up versus continuation cost of the demonstration will remain mostly an academic or accounting exercise until the number of voucher

Table III -7

COMPARISONS OF FIRST AND SECOND YEAR GRANTS

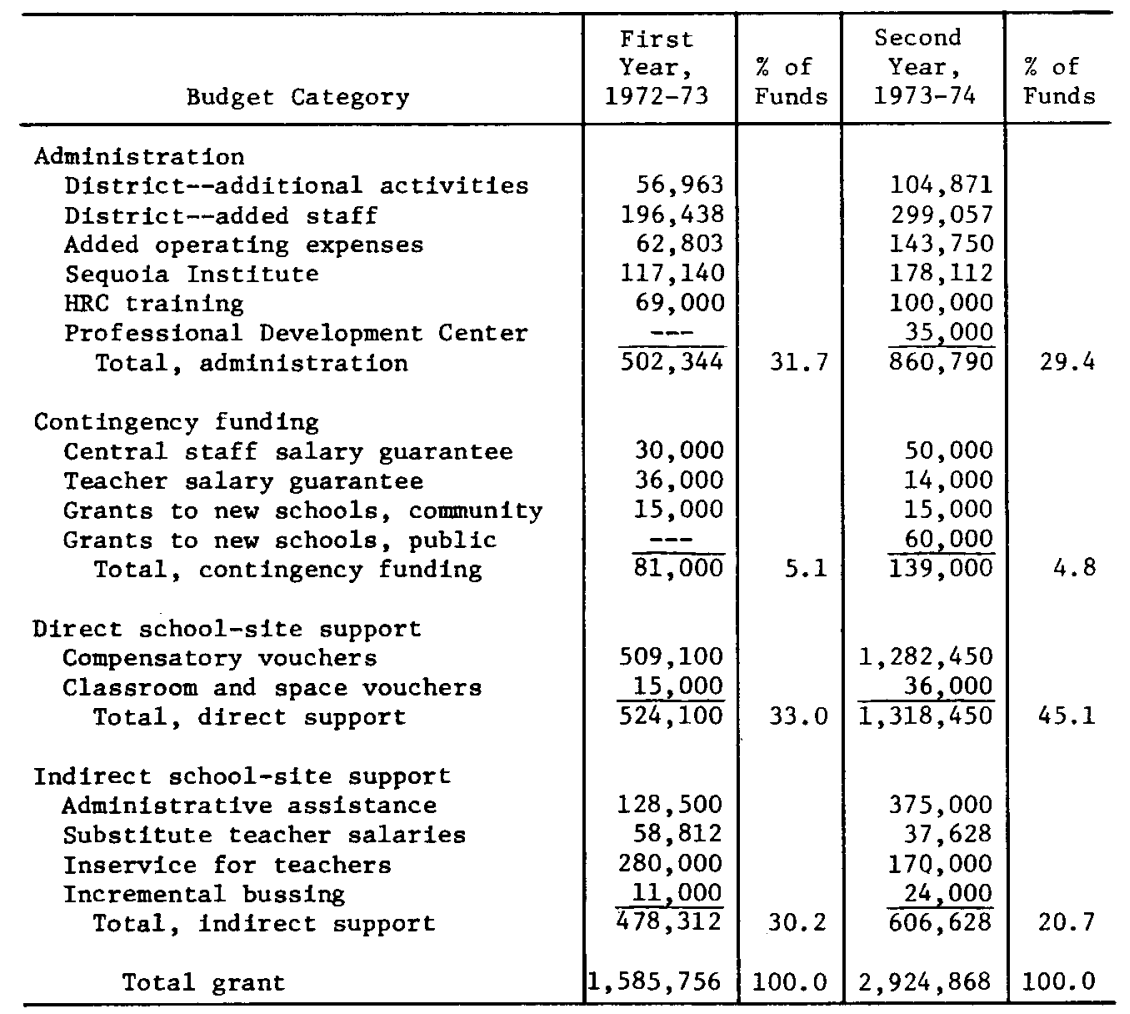

SOURCE: The federal grant and related correspondence as of March 1973. 
schools stops increasing. There should be, however, some impact on costs from learning curves as the experience of the initial schools is transferred to the new schools, as the voucher-enabling management systems are developed, and as the expertise of the central district staff in dealing with the requirements of the voucher concept increases.

The administrative assistance allowance to the schools based on their experience in the voucher demonstration provides tangible evidence of a planned decrease in operational cost as the demonstration moves out of the start-up phase. The same type of decreasing allowance applies to inservice training; the flat allowance of $\$ 30,000$ per school in the first year of the demonstration has now changed to a per student allowance, with a school receiving $\$ 50$ per student for the first year of participation and $\$ 10$ per student for the second year (no federal funds are to be used for inservice training after the second year). The district's effort to develop and install the school-level income/outgo budgeting system and the more timely and accurate attendance system, and to maintain dual attendance systems during the transition, also entails a one-time cost-estimated to be less than $\$ 75,000$. This does not include the cost of entering the 5000 students of the second year or the school-site incremental administrative costs.

The voucher component of parental participation is definitely an incremental cost to district operations and, at about 30 percent of administrative costs, is a relatively high-cost activity that will continue. Collecting and distributing adequate information about the choices open to parents make up the major portion of the cost of parental participation. But, as with the other activities, its cost should decrease somewhat with experience and after the procedures and techniques are developed. After the start-up period, voucher demonstration participants should have a better idea of the type of information needed by parents, how to collect it, when parents need it, and how best to get the information to them.

Additional insights can be gained by comparing the 1973-74 grant with the projected grant for 1974-75 even though supplemental grants, resulting from negotiations, may significantly affect the cost of specific activities. (See Table III-8.)

The grant for 1974-75 covers a voucher demonstration of the same size as in 1973-74; that is, ten elementary schools and three middle schools with 45 minischools and approximately 9000 students. The direct school-site support remains the same. The decrease of about 50 percent in the indirect school support occurs primarily because the schools are in their second and third year of participation and have a lesser need for inservice training and school-site administrative support. The small decrease of 16 percent in central administration is attributable to a reduction in the central district staff time devoted to the voucher demonstration and in staff time for management systems development. 
Table III-8

COMPARISON OF SECOND AND THIRD YEAR GRANTS

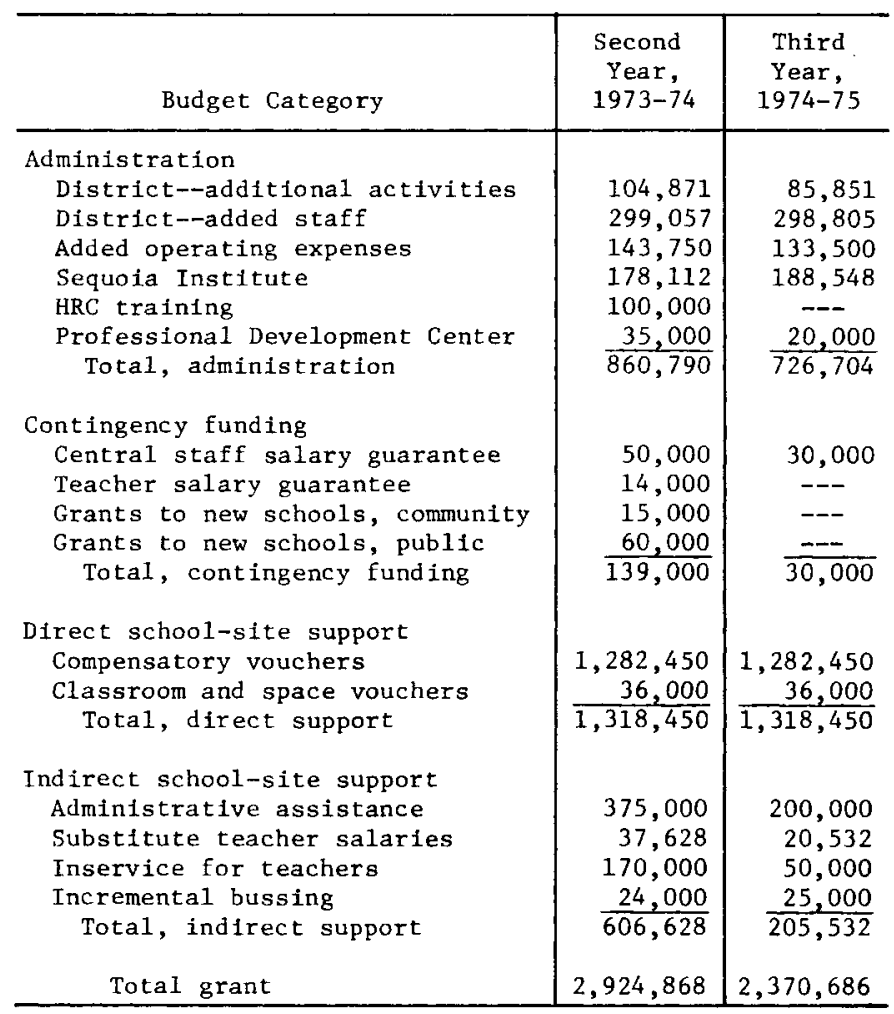

SOURCE: Federal grant and related correspondence as of March 1973. 


\section{Appendix IV}

\section{THE VOUCHER FINANCIAL INFORMATION SYSTEM \\ by William S. Furry and Sue A. Haggart}

All federal voucher demonstration grants to Alum Rock have included the "special condition" requiring the district to develop and implement an "income/ outgo budget" for the voucher mini-schools. The system was de- signed during the first year of the project and was in operation at the beginning of the second year. The income/outgo report, to be distributed monthly to the mini-schools, displays the income changes, and corresponding expenditure budget changes, resulting from student transfers during the report period.

In the income/outgo accounting system, each mini-school is treated as an independent accounting entity; that is, as a budget, or cost, center with a self-balancing budget. The report shows a mini-school's sources and amounts of income and its

' expenditures, encumbrances, and unencumbered balance. The computer program that produces the report automatically adjusts the mini-school's reserve account at the end of the period to reflect changes in projected annual basic and compensatory voucher income.

\section{WHY INCOME/OUTGO ACCOUNTING SYSTEM IS NEEDED}

Financial accounting systems are constructed to provide information for decisionmakers. In Alum Rock we find four groups of decisionmakers: the school board, district administrators, school staffs, and community members. The financial information which these groups require in a voucher education system can best be understood in terms of three salient characteristics of that system: decentralization of the design of instructional programs and the selection of resource inputs, parent choice, and an enrollment economy.

Teachers are deeply involved in designing educational programs and selecting resource inputs. They need to know how much discretionary income is available for their mini-school; how much of it already has been spent; and how much is left to be spent.

Parents in making their choice of instructional programs for their children need to know the priorities given by the mini-schools to various purposes, activities, and resources. In addition, parents should be able to verify that mini-school income is in fact being spent for the purposes advertised in promotional literature. And, further, parents should be aware of rising or falling enrollments as a clue to the satisfaction or dissatisfaction of other parents with mini-school performance.

Finally, the enrollment economy of the voucher demonstration requires that the accounting system have the capacity to adjust automatically the projected annual income of the mini-school. Since, during the year, only estimates of the actual average daily enrollment for the full year are available, and since students are free at any time to transfer from one mini-school to another, school staffs need periodic reports on the income trend in order to make appropriate changes in expenditure budgets.

The income/outgo system and its monthly report, described below, meet these 
needs of parents and school staffs. In addition, the system will furnish the financial information normally required by the school board, district administration, voters, and outside organizations and individ- uals. These needs relate to the financial condition and expenditure accountability of the district. Mini-school budgets can be aggregated to the building level and combined with the budgets of nonvoucher schools to provide a picture of total district activity, of the degree to which board policies are being carried out, and of the general financial position of the district.

\section{THE MONTHLY REPORT OF THE INCOME/OUTGO BUDGETING SYSTEM}

The periodic report for each mini-school contains three sections: an income report, an expenditure report, and a cost analysis section.

The income report shows, for each income source (such as Basic Voucher, Compensatory Voucher, Model Cities, Administrative Allowance, Psychological Services, and so forth), the budget at the beginning of the school year, the budget at the beginning of the current report period, the amount of change during the period, and the projected annual income at the end of the period. In addition, it displays the amount of subsidies or contributions incurred by the mini-school.

The expenditure report shows for each program (such as Basic Instruction, Music, Compensatory, Physical Education, Model Cities, and others) an account within the program (teacher salaries, equipment, basic supplies, and so forth), the budget at the beginning of the school year, the budget at the end of the current report period, adjustments made during the period, this-period and year-to-day expenditures and encumbrances, and the unencumbered balance at the end of the period. The report displays totals for individual programs, all programs, and the reserve accounts which absorb minor fluctuations in income.

The cost analysis report is a supplementary document containing comparative financial data for the voucher district. Comparisions can be made of expenditure budgets for:

1. Accounts with programs,

2. Total program,

3. Total of all programs,

4. Reserve accounts, and

5. Total of all programs and reserve accounts.

Two forms of comparison are available at each of these levels of aggregation. First, the expenditure budgets at the end of the current period can be compared with:

1. The budget at the beginning of the school year (the board-approved budget),

2. A hypothetical budget based on average salaries (the expenditure report uses actual salaries), and

3. A hypothetical budget based on districtwide per pupil expenditures.

The second form of comparison available from the cost analysis report is between actual budgeted expenditure in a mini-school and the average actual budgeted expenditure of all mini-schools. Thus, for each account, program, and all programs, the observer can compare the level of expenditure per pupil budgeted in one minischool with the average for all mini-schools. Finally, by looking at the reports of individual mini-schools, any desired comparison between mini-schools in budgeted expenditure per pupil can be made. 


\section{PRODUCTION OF THE INCOME/OUTGO REPORT}

The income/outgo report is prepared monthly, with the reporting period corresponding to the Santa Clara County fiscal calendar periods. Three financial inputs are required by the computer program which produces the mini-school income/ outgo report. First, expenditure data (encumbrances and expenditures) are obtained from the district's computerized expenditure ledger system. Second, the status of basic and compensatory voucher income of the mini-schools at the end of the report period is picked up from the voucher dollar allocation report (VDAR). The VDAR uses data generated by the Alum Rock Attendance System (ARAS). And third, amounts of changes in mini-school income from nonvoucherized sources are provided by the voucher accountant. The income/outgo program generates its reports from these three data sets.

\section{IMPACT OF MINI-SCHOOL ACCOUNTING}

Alum Rock has progressed from districtwide accounting for instructional resources to the school level and now to the mini-school level. Those familiar with school district budget will recognize the increased information available at the school level, as shown in Table IV-1. The district, moreover, is as close as any in the nation to accounting for resources by classroom via the mini-school budgets.

Financial voucherization of the district has evolved slowly. During the first year a good deal of effort went into developing resource allocation rules and values. These rules, summarized in Table IV-2, are the basis for determining the school and mini-school initial income and income changes during the year as a result of student transfers.

These changes have not been easy. The number of budget centers has leaped from one to more than ninety. Districtwide number of purchase orders to be processed has increased in three years from 3000 to more than 10,000 . The rules governing resource allocation have become so complex that it has been impossible to develop standard forms for school staffs to compute their own budgets. The district has had to employ an experienced systems analyst to design and install new student and financial accounting systems. And a new position in the hierarchy, that of Controller, has been created to head the accounting department and revamp the purchasing and payroll systems.

The effect on the district of the availability of financial information at the mini-school level will be studied in detail by Rand. At this time, we will suggest two possible consequences of significance.

First, the existence of financial data for mini-schools may make an issue of the role of the district's Board of Trustees in school and mini-school expenditure decisions. Board members, at the final budget session in August 1973, in fact, asked whether, by approving the state-required budget document (which is a function and object classification for the district as a whole), they were also giving their approval to every mini-school budget.

Second, the financial data at the mini-school level may highlight the relationship between money and the nature of the instructional program that can be provided. The ed ational value of different kinds of personnel, materials and equipment, and suf t services may be increasingly questioned. The fact that something must be given up in order to purchase something else may be more clearly realized at the mini-school level and teachers may seriously consider alternative ways to achieving goals. 


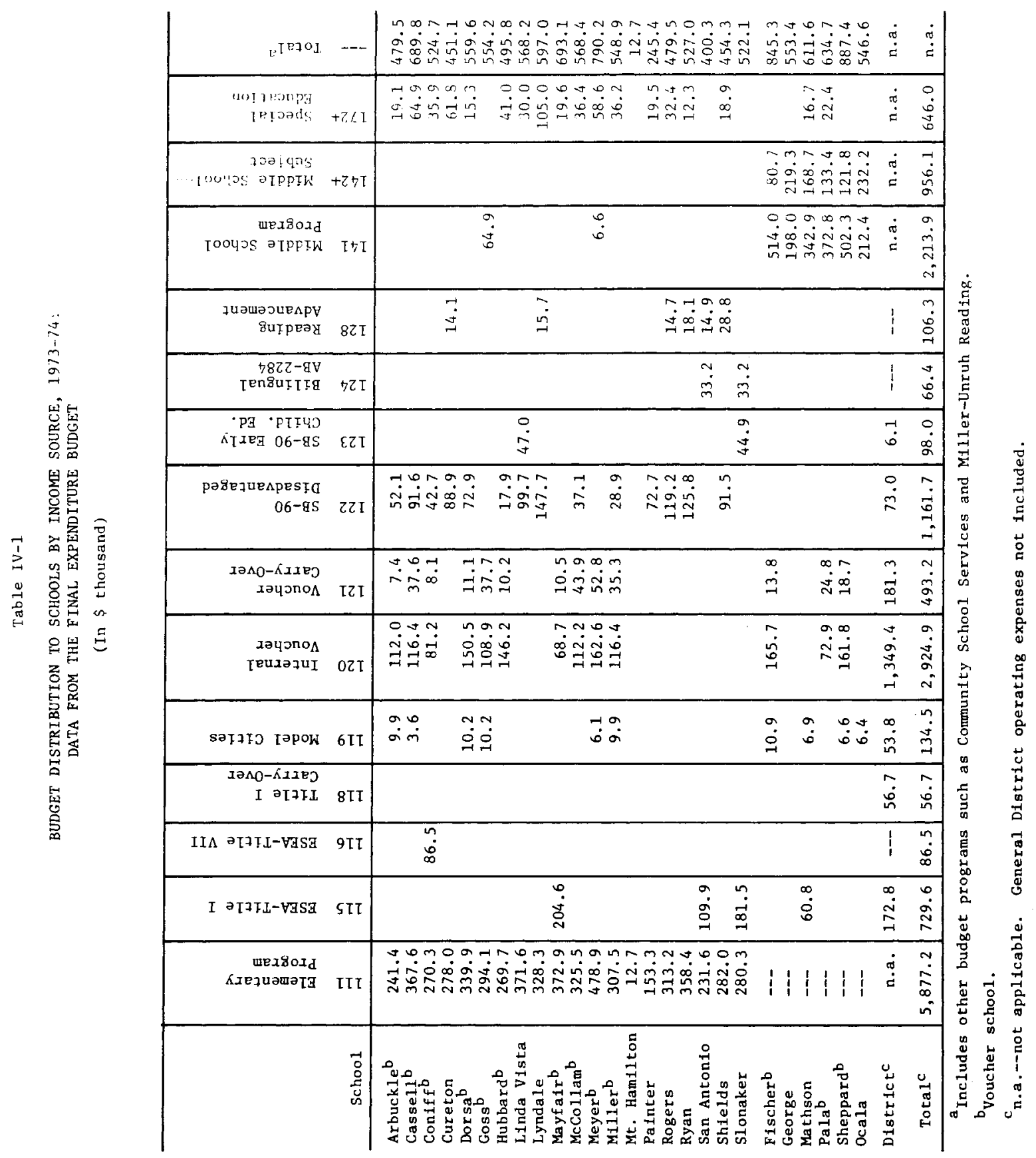


Table IV-2

VOUCHER DEMONSTRATION RESOURCE ALLOCATION VALUES AND BASES, 1972-73 AND 1973-74

\begin{tabular}{|c|c|c|c|}
\hline & Income Source & $1972-73$ & $1973-74$ \\
\hline \multirow[t]{2}{*}{1.} & Basic Voucher & $\begin{array}{ll}\text { K-6: } & \$ 787.86 / \text { pupil } \\
7-8: & \$ 1041.38 / \text { pupil }\end{array}$ & $\begin{array}{l}\text { K-6: } \quad \$ 842.63 / \text { pupil } \\
7-8: \quad \$ 1047 / 38 / \text { pupil }\end{array}$ \\
\hline & $\begin{array}{l}\text { Less Central } \\
\text { Services Payback }\end{array}$ & $\$ 259.53 /$ pupil & $\$ 289.63 /$ pupil \\
\hline 2 . & Compensatory Voucher & $\begin{array}{ll}\mathrm{K}-6: & \$ 237.77 / \mathrm{eligible} \\
7-8: & \$ 301.55 / \mathrm{elig} 1 \mathrm{ble}\end{array}$ & 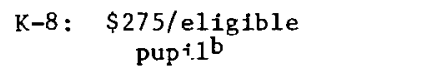 \\
\hline 3. & $\begin{array}{l}\text { Administrative } \\
\text { Allowance }\end{array}$ & $\begin{array}{l}\$ 18,000 \text { flat grant for } \\
\text { each school }\end{array}$ & $\begin{array}{l}\text { First year, } \$ 25,000 \\
\text { Second year, } \$ 20,000\end{array}$ \\
\hline 4. & Inservice Allowance & $\$ 30,000$ & $\begin{array}{l}\text { First year, } \$ 50 / \text { pup } 11 \\
\text { Second year, } \$ 10 / \text { pupil }\end{array}$ \\
\hline 5. & Psychological Services & $\$ 6.73 /$ pupil & $\$ 7.75 /$ pup 11 \\
\hline 6. & Curriculum Coordinators & $\$ 7.46 /$ pup11 & $\$ 10.73 /$ pupi1 \\
\hline 7. & Educational Media & $\$ 4.76 /$ pup 11 & $\$ 5.68 /$ pup 11 \\
\hline 8. & Curriculum Voucher & $\$ 30 /$ Program Teacher & $\$ 30 /$ Program Teacher \\
\hline 9. & Carryover Funds & $\begin{array}{l}\text { None (except inservice } \\
\text { allowance--see No. } 4 \text { ) }\end{array}$ & $\begin{array}{l}\text { Funds not spent } 1972-73 \\
\text { may be carried over. }\end{array}$ \\
\hline 10. & $\begin{array}{l}\text { Categorical Income } \\
\text { (Title I, Model } \\
\text { Cities, SB 90, } \\
\text { Title VII, etc.) }\end{array}$ & $\begin{array}{l}\text { Flat grants to schools } \\
\text { economic disadvantage, } \\
\text { continuation of progran } \\
\text { in schools. }\end{array}$ & $\begin{array}{l}\text { allocated on basis of } \\
\text { educationa1 need, and for } \\
\text { s already in existence }\end{array}$ \\
\hline 11. & $\begin{array}{l}\text { State Excess Cost for } \\
\text { Education of Special } \\
\text { Students }\end{array}$ & $\begin{array}{l}\text { Special education } \\
\text { programs budgeted } \\
\text { centrally. }\end{array}$ & $\begin{array}{l}\text { Allocated to special } \\
\text { education mini-schools on } \\
\text { a per-class basis. Amount } \\
\text { varies by program. }\end{array}$ \\
\hline 12. & $\begin{array}{l}\text { Special Education } \\
\text { Subsidy }\end{array}$ & $\begin{array}{l}\text { Special education } \\
\text { programs budgeted } \\
\text { centrally. }\end{array}$ & $\begin{array}{l}\text { Allocated to special } \\
\text { education mini-schools to } \\
\text { pay for district mandated } \\
\text { additional personnel. }\end{array}$ \\
\hline 13. & $\begin{array}{l}\text { Basic Program Subsidy } \\
\text { or Contribution }\end{array}$ & $\begin{array}{l}\text { A reduction of or addit } \\
\text { Equals the difference } \\
\text { bastc program personnel } \\
\text { of these personnel. }\end{array}$ & $\begin{array}{l}\text { ion to basic voucher income. } \\
\text { etween actual salaries of } \\
\text { and the average salary cost }\end{array}$ \\
\hline
\end{tabular}

\footnotetext{
a Pupil in average dafly enrollment.

bayfair School recelves $\$ 50 /$ eligible pupil and a flat Title I grant. Students in Conniff's Title VII program are not eliglble for compensatory vouchers.
} 
Appendix V-A

\section{CLASSROOM OBSERVATION CHECKLIST}

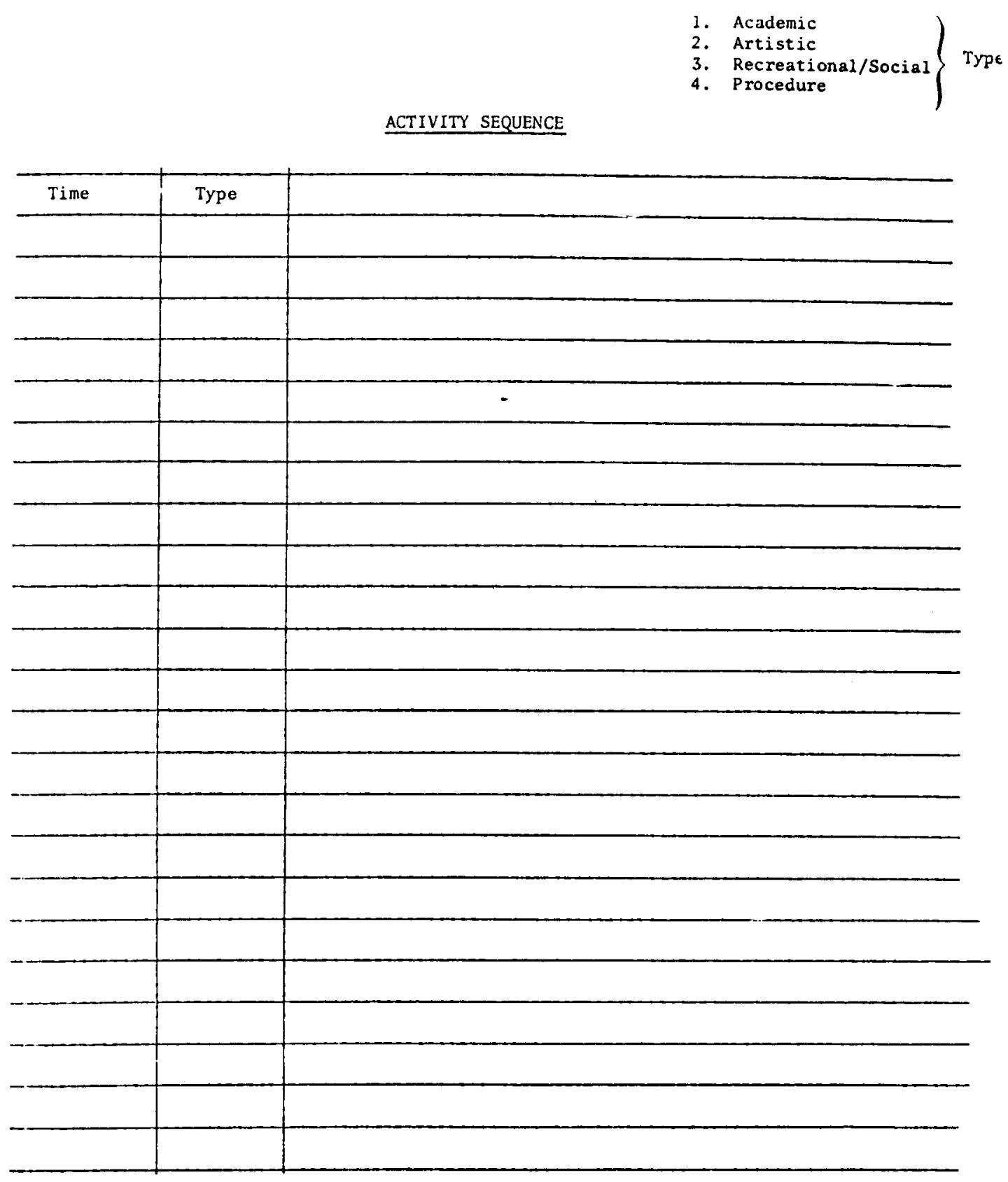


CLASSROOM RESOURCES

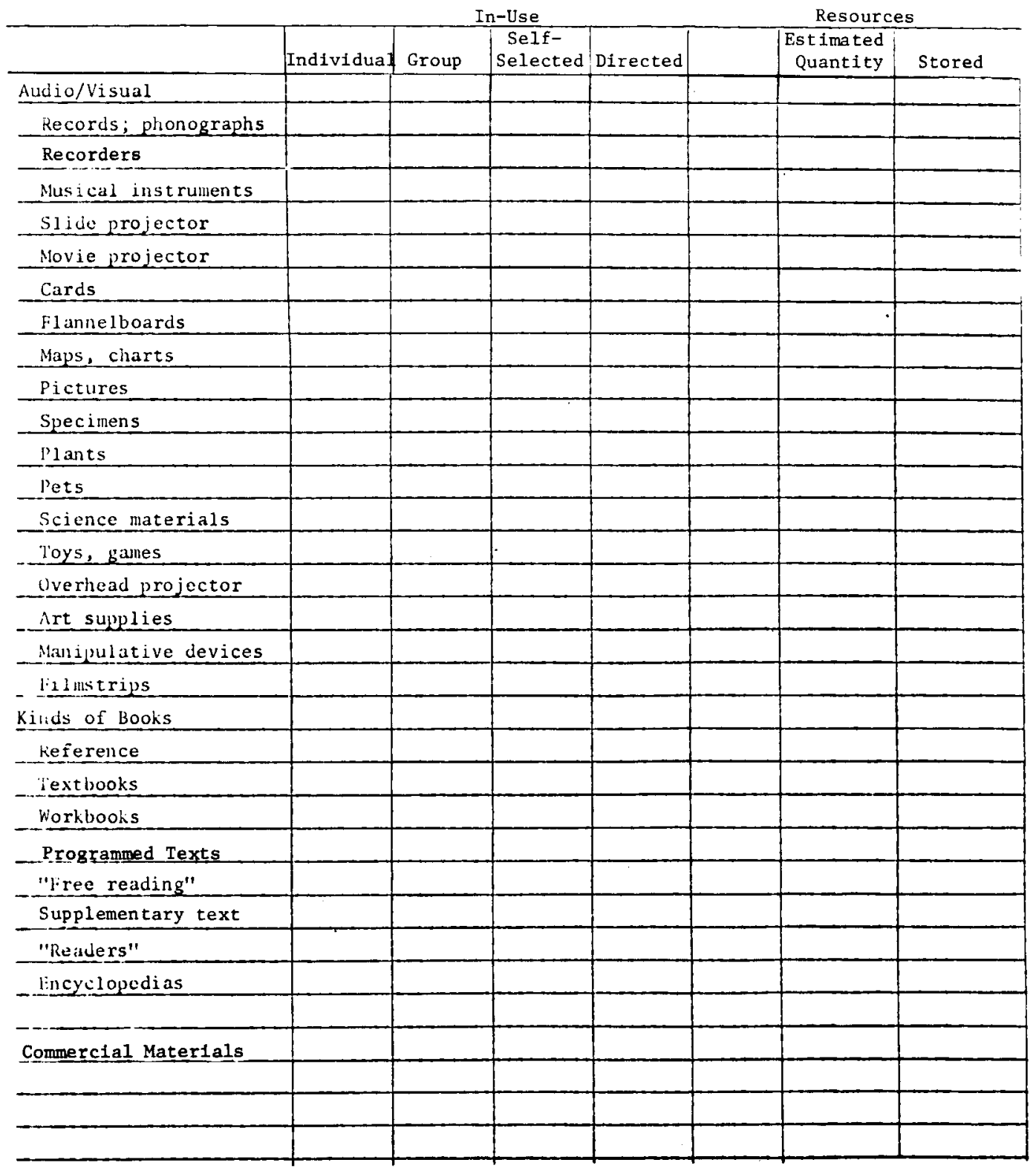


INSTRUCTIONAL STRATEGY

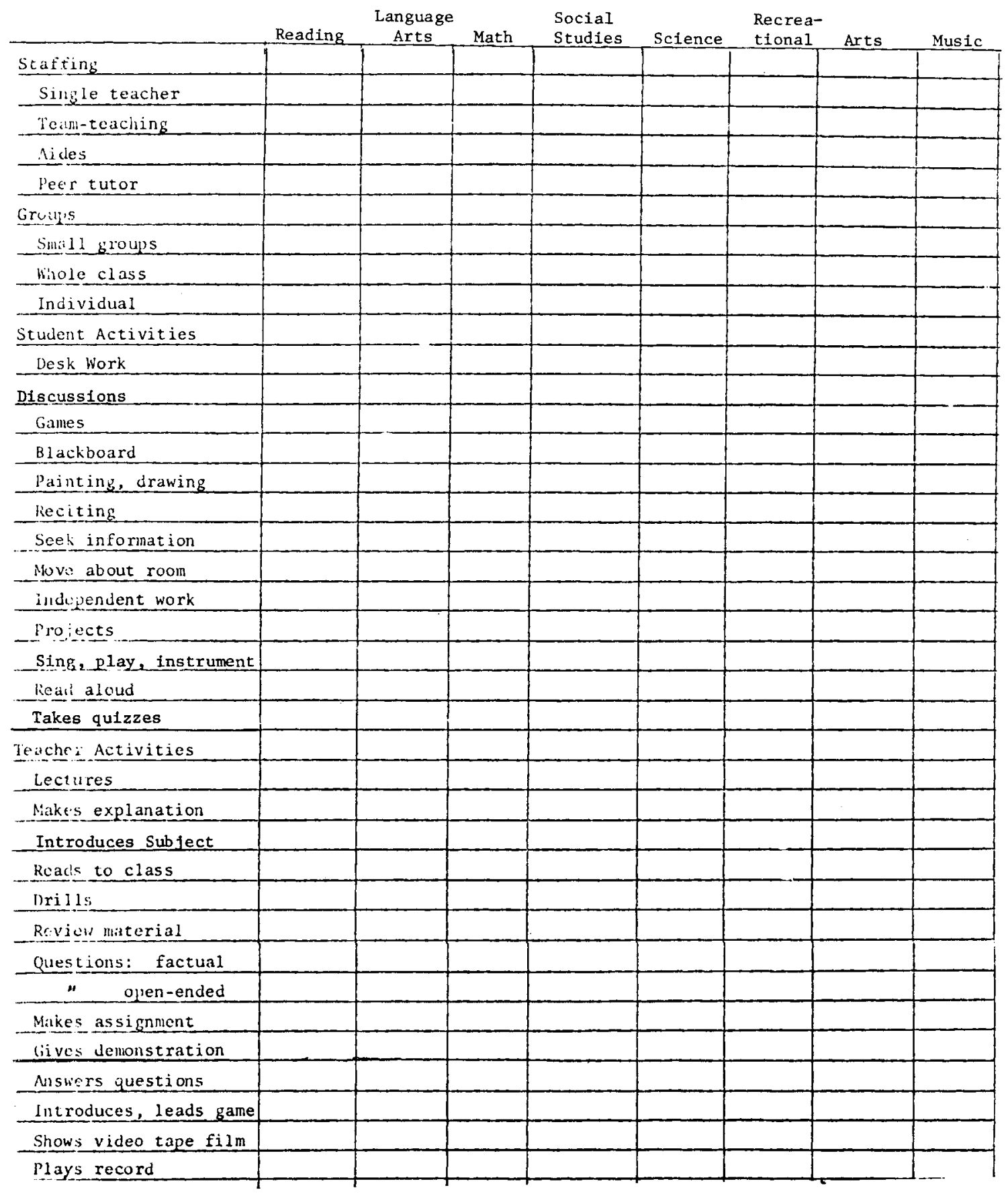




\section{Appendix V-B}

\section{INFORMATION PACKAGE FOR MEETINGS WITH MINI-SCHOOL FACULTIES IN THE SPRING}

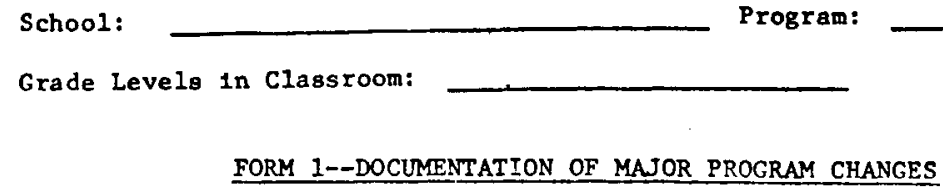

Please 11st, In chronological order, major changes in your program since September of 1972 . For each change, give the nature of the change, the approximate date, and the reason for the change. One or two sentences should be enough; you will have an opportunity to discuss the changes in more detall during our meeting.

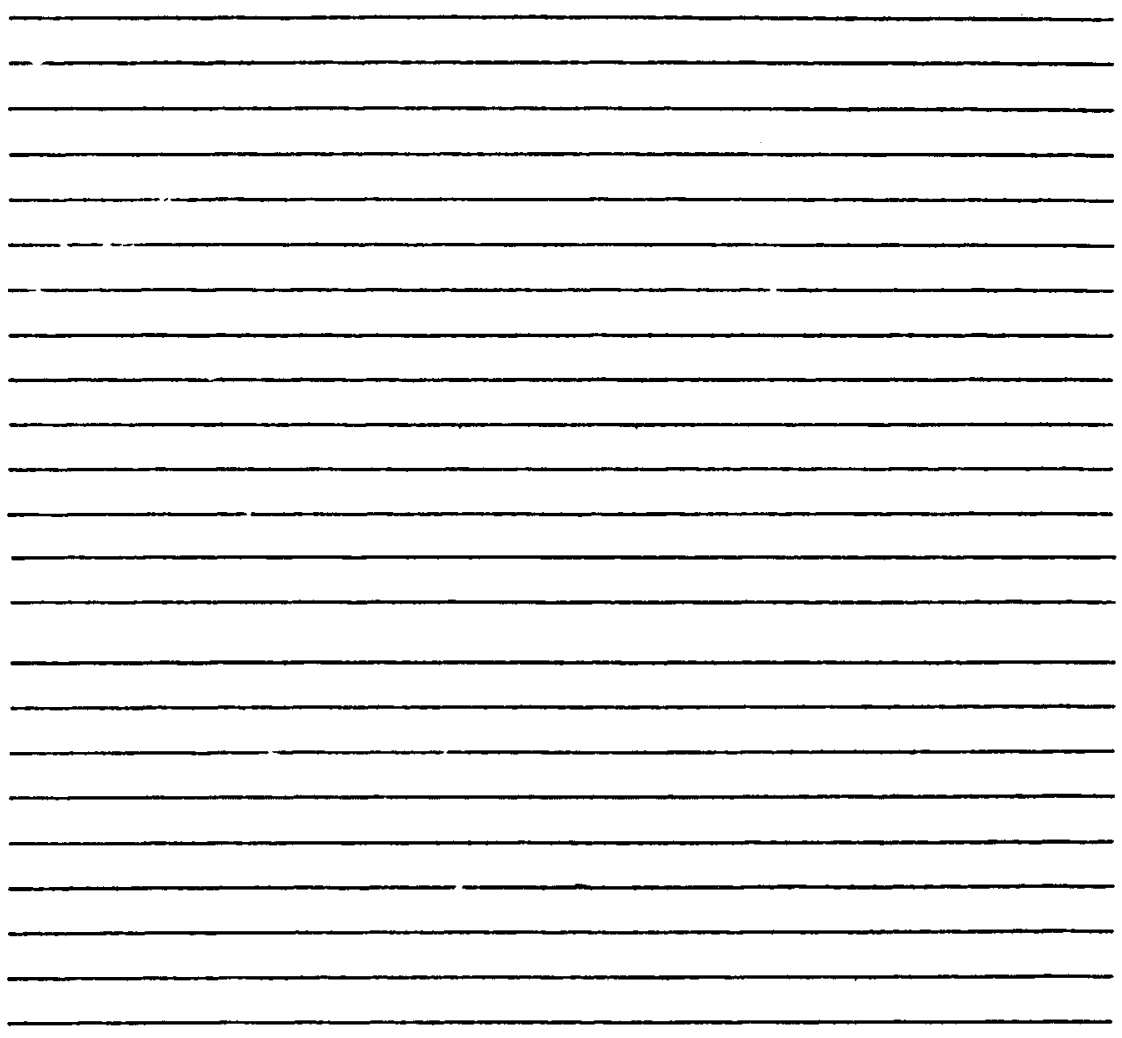


School:

Program:

Grade Levels In Classroom:

FORM 2--ESTIMATED ALLOCATION OF CLASSROOM TIME

For each subject, please give an estimated t1me per week. If you don't teach the subject, fill-in a zero. If you need more subject spaces; divide a space into two with a slash. For example, if there 1s a separate health studies period--show Science/Health and $90 / 40$ for the time.

Please remember that this is student instructional and activity time. If you have students on a staggered schedule, give the estimated time for only one group.

\begin{tabular}{|c|c|c|c|c|c|c|c|c|c|}
\hline \multirow[b]{2}{*}{ Su'sject ireas } & \multicolumn{9}{|c|}{ Estimated Minutes Per Veek by Grade } \\
\hline & $\mathbf{K}$ & 1 & 2 & 3 & 4 & 5 & 6 & 7 & 8 \\
\hline Lanquage Arts (a) & & & & & & & & & \\
\hline Reading & & & & & & & & & \\
\hline Arithmetic & & & & & & & & & \\
\hline jocial Studies & & & & & & & & & \\
\hline Science & & & & & & & & & \\
\hline Art & & & & & & & & & \\
\hline Music & & & & & & & & & \\
\hline Proiran Activity & & & & & & & & & \\
\hline Whysical Educati & & & & & & & & & \\
\hline Recuss and Break & & & & & & & & & \\
\hline Daily Routine ${ }^{(c)}$ & & & & & & & & & \\
\hline Total Minutes & & & & & & & & & \\
\hline
\end{tabular}

(a) Includes: Oral/written expression, spelling, handwriting, forelgn languages.

(b) Briefly describe on the back of this page the nature of the activities.

(c) Includes: Opening exercises, lunch, pupil-teacher planning. 
School:

Program:

Grade Levels in Classroom:

FORM 3-MAJOR INSTRUCTIONAL MATERIALS USED

Please list the major instructional materials used. (As a criterion, consider importance rather than dollars spent.) Give publisher and/or author, if applicable--e.g., BRL-SILAS or Mayne/Ferguson Math Program and Indicate grade levels where materials are used.

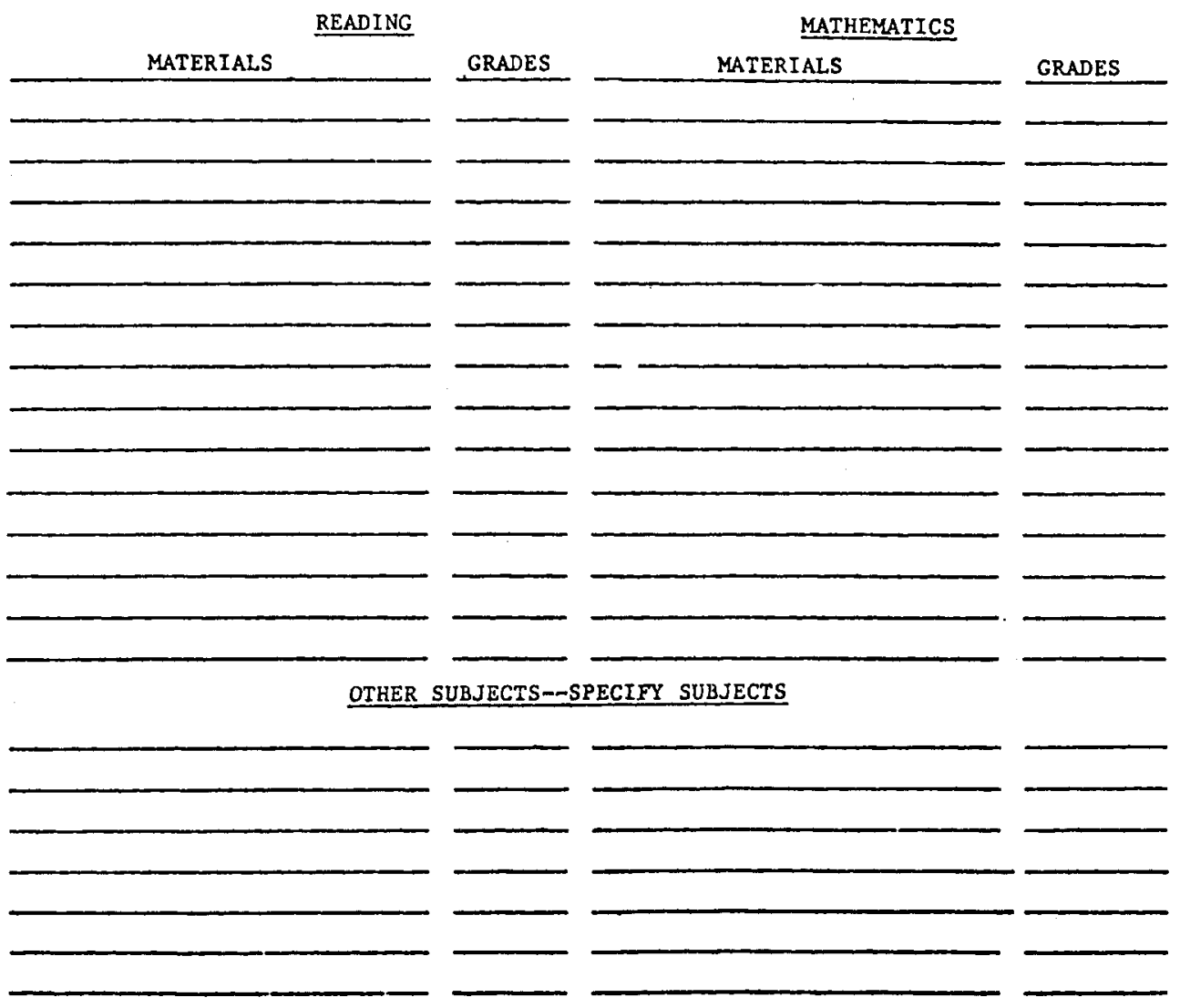


School:

Program:

FORM 4--FIELD TRIPS AND SPECIAL PROJECTS

Please ligt the field trips you have taken this year, including those planned for the rest of the year. Show grade levels Involved and give an estimate of time--2 hours, half a day, all day.

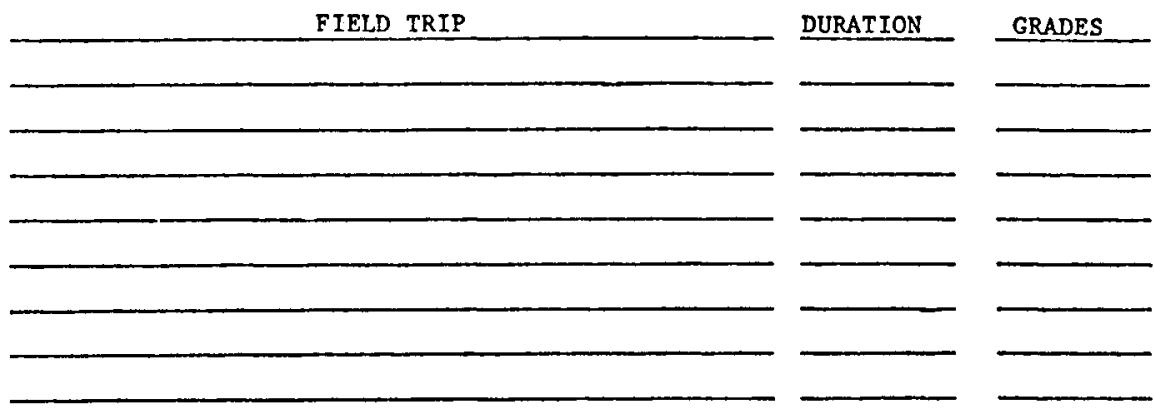

For special projects or activities, briefly describe the profect, the grades Involved, the number of students participating (the whole class or different profects for different groups of students).

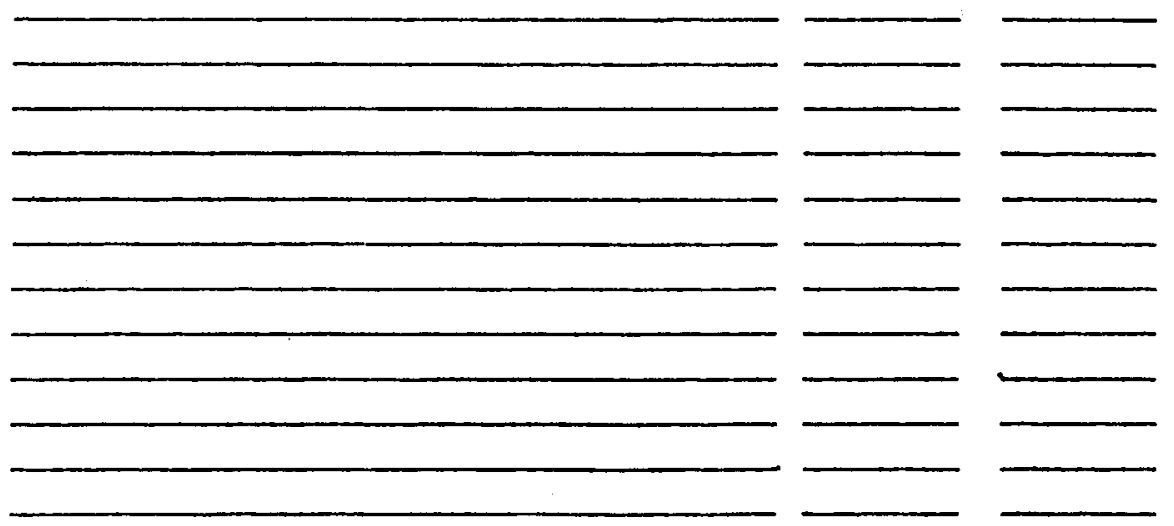




\title{
Appendix V-C \\ EDUCATIONAL COSTS BY SCHOOL, MINI-SCHOOL, AND CLASSROOM
}

\author{
by Sue A. Haggart
}

\section{SCHOOL AND MINI-SCHOOL BUDGET LEVELS}

The voucher demonstration started before the budget machinery to support it was ready. The year before the demonstration, however, was a year of phasing into a partially decentralized school system and the voucher demonstration funding carried with it a special condition that a school level budgeting system be developed. During the 1972-73 year, therefore, the information at the school level was caught in the middle between the conventional line-item district budget format and the emerging school level budget design. Budget information at the mini-school level is even more elusive, but is worth retrieving in order to establish a mini-school budgetary baseline for the 1972-73 voucher demonstration (see Table V-C.1 and V-C.2).

The school level budget includes funds for the basic instructional program (Program 111 for elementary school students and Program 141 for middle school students), a subject allocation for middle school students, categorical aid programs, centralized services allowance, and for the voucher schools, Program 120-Internal Voucher School Program. The Internal Voucher School Program money is the budgeted amount for the compensatory voucher and the voucher-provided administrative allowances to the schools.

The Program 111 funds for voucher elementary schools in 1972-73 show a median of $\$ 472$ per student-considerably lower than the $\$ 535$ median of the nonvoucher schools-and a range of $\$ 458$ to $\$ 637$ per student. Pala has a per student amount of $\$ 683$ for Program 141 -slightly higher than the median of $\$ 669$ for the nonvoucher middle schools. The differences are not related to either school size (a larger number of students yields a lower per student figure) or to the salary differences of the school's teaching staff. Rather, the differences reflect the district policy of equalizing total funds for each school. In 1973-74, Mayfair and Coniff eligible students will receive a "discounted" voucher and more SB 90 state funds will be allocated to schools not receiving funds from other services.

Because of differing proportions of students eligible for the compensatory voucher, the dollars per student for the twenty-two mini-schools ranged from $\$ 586$ (Meyer Basic Skills) to $\$ 969$ (Miller Individualized) (see Fig. V-C.1). The data illustrating the variation in dollars per student for the schools and mini-schools are subject to a very real limitation. Given the state of the art in conventional budgeting practices, determining a dollar per student factor by examination of the records at any time after the figures were initially prepared can be in error. The error arises because the exact enrollment figures on which the estimates are based are not carried along with the budget estimates in later publication of the data. Ordinarily, this presents no problem because of the one-time nature of the initial calculations and because a "backward look" at the data is rarely taken. Here, the dollars per student for Miller could be overestimated because of the mismatch of the student enrollment and the budget figure. The point to be made is that there is a difference in the dollars per student for the mini-schools and the absolute difference is not of great importance. 
Table V-C.1.

DISTRIBUTION OF FUNDS TO ALUM ROCK ELEMENTARY SCHOOLS, 1972-73

(In $\$$ per regular student)

\begin{tabular}{|c|c|c|c|c|c|}
\hline School & $\begin{array}{c}\text { Total } \\
\$ \text { per } \\
\text { Student }\end{array}$ & $\begin{array}{l}\text { Elementary } \\
\text { Program } 111\end{array}$ & Title I & $\begin{array}{c}\text { Compensatory } \\
\text { Voucher }\end{array}$ & other ${ }^{b}$ \\
\hline $\begin{array}{l}\text { Title I schools } \\
\text { San Antonfo } \\
\text { Arbuckle } \\
\text { Hubbard } \\
\text { Mayfair } \\
\text { Slonaker } \\
\text { Medtan }\end{array}$ & $\begin{array}{l}915 \\
816 \\
782 \\
724 \\
722\end{array}$ & $\begin{array}{l}623 \\
538 \\
534 \\
481 \\
\frac{449}{534}\end{array}$ & $\begin{array}{l}292 \\
246 \\
248 \\
243 \\
240\end{array}$ & & 32 \\
\hline $\begin{array}{l}\text { Voucher schools } \\
\text { Cassell } \\
\text { Goss } \\
\text { McCollam } \\
\text { Meyer } \\
\text { Miller } \\
\text { Median } \\
\text { Nonvoucher, } \\
\text { non-Title I schools } \\
\text { Painter } \\
\text { Dorsa } \\
\text { Cureton } \\
\text { Ryan } \\
\text { Linda Vista } \\
\text { Rogers } \\
\text { Shields } \\
\text { Lyndale } \\
\text { Median }\end{array}$ & $\begin{array}{l}654 \\
563 \\
552 \\
552 \\
554 \\
503 \\
463 \\
452\end{array}$ & $\begin{array}{l}523 \\
458 \\
472 \\
455 \\
\frac{637}{472} \\
\\
649 \\
538 \\
549 \\
552 \\
533 \\
500 \\
461 \\
\frac{449}{535}\end{array}$ & & $\begin{array}{l}168 \\
179 \\
195 \\
159 \\
236\end{array}$ & $\begin{array}{r}5 \\
25 \\
3 \\
-- \\
20 \\
3 \\
2 \\
3\end{array}$ \\
\hline
\end{tabular}

${ }^{a}$ The elementary level $(\mathrm{K}-6)$ compensatory voucher was $\$ 237.77$ for students ellglble for the free lunch program. The cost per student shown here is based on total enrollment of regular students. For Miller School, almost all the students apparently are eligible for the free lunch program.

bodel Cities and Community School programs.

${ }^{c}$ Coniff, a Title VII school, is not included.

${ }^{d}$ Mt: Hamilton, with less than ten students, is not included.

Table V-C.2

DISTRIBUTION OF FUNDS TO ALUM ROCK MIDDLE SCHOOLS, 1972-73

(In \$ per regular student)

\begin{tabular}{|c|c|c|c|c|c|}
\hline School & $\begin{array}{l}\text { Total } \\
\text { \$ per } \\
\text { Student }\end{array}$ & $\begin{array}{l}\text { 141-152 Middle } \\
\text { School Plus } \\
\text { Extracurricular }\end{array}$ & $\begin{array}{c}\text { Compensatory } \\
\text { Voucher }\end{array}$ & $\begin{array}{l}\text { Middle } \\
\text { School } \\
\text { Library }\end{array}$ & other ${ }^{b}$ \\
\hline Nonvoucher & & & & & \\
\hline Mathson & 893 & $821^{c}$ & -- & 18 & 54 \\
\hline Sheppard & 716 & 688 & -- & 15 & 13 \\
\hline George & 670 & 649 & -- & 21 & -- \\
\hline $\begin{array}{l}\text { Fisher } \\
\text { Median }\end{array}$ & 665 & $\frac{630}{669}$ & -- & 15 & 20 \\
\hline Voucher--Pala & 859 & 683 & 153 & 23 & -- \\
\hline
\end{tabular}

${ }^{a}$ The middle school level compensatory voucher was $\$ 301.55$ for students eligible for the free lunch program. The cost per student is based on total enrollment of regular students. At $\mathrm{Pala}, 387$ students out of 601 apparently were eligible.

bodel Cities and Communtty Schools programs.

"Mathson has a "special allowance" of approximately $\$ 90,000$ or $\$ 138$ per student. 


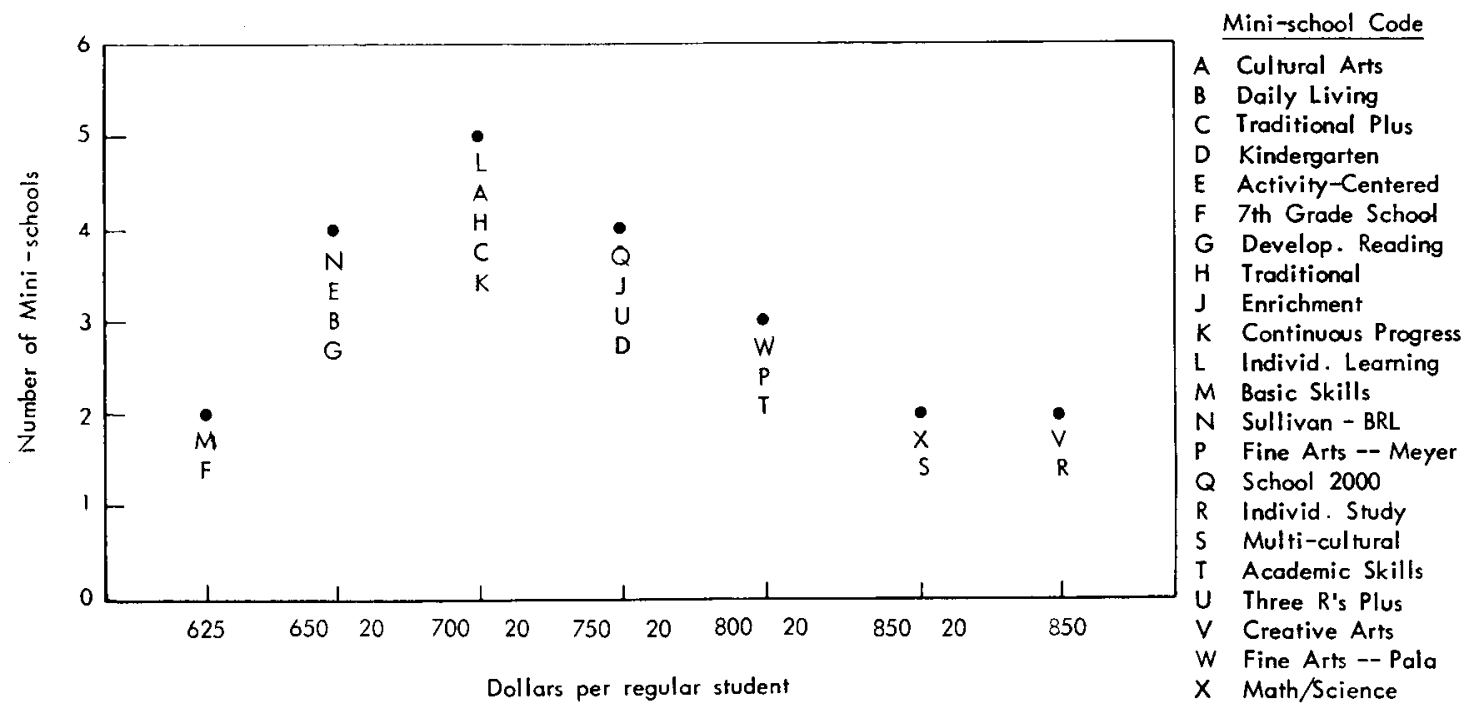

Fig. V-C.1-Distribution of mini-schools, by dollars per regular student

An examination of the mini-school budgets with the voucher host-school also reveals some interesting variations (see Fig. V-C.2 and Table V-C.3). Here the variations can be explained, for the most part, by variations in the enrollment of both the host-school and the mini-school and in the per pupil difference for building personnel for the mini-school.

The unembellished, cold totals for the basic voucher and the compensatory voucher shown in the mini-schools' budgets do not tell the story of the voucher demonstration's impact at the school level. The voucher allocation rules may give the impression that everything is set in concrete. This was not the case even in the first year. Voucher schools and mini-schools did have discretionary money; they did differ in what they spent the money for. The voucher schools had the conventional $\$ 8.50$ per student allocation for instructional supplies. This, in effect, is the discretionary money for the school as a whole; and, along with the basic voucher funds, the instructional supplies allocation is under the control of the principal. The manner in which the voucher school's administrative allowance was to be spent was also under the control of the principals. The compensatory voucher funds and some of the inservice training and planning funds were under the control of the mini-school faculties.

It should be noted that the "compensatory" funds were not earmarked for compensatory activities, such as remedial reading, or for specific students. One mini-school faculty elected to spend some of its discretionary money to hire a parttime teacher for its program. Another voucher school decided to keep two "excess" teachers by paying their salaries from their discretionary pot of money. In these instances, the schools and mini-schools were decreasing the student-teacher ratio as an option they elected to take. A mini-school is not allowed to increase the studentteacher ratio, however, as a way of gaining discretionary money. 


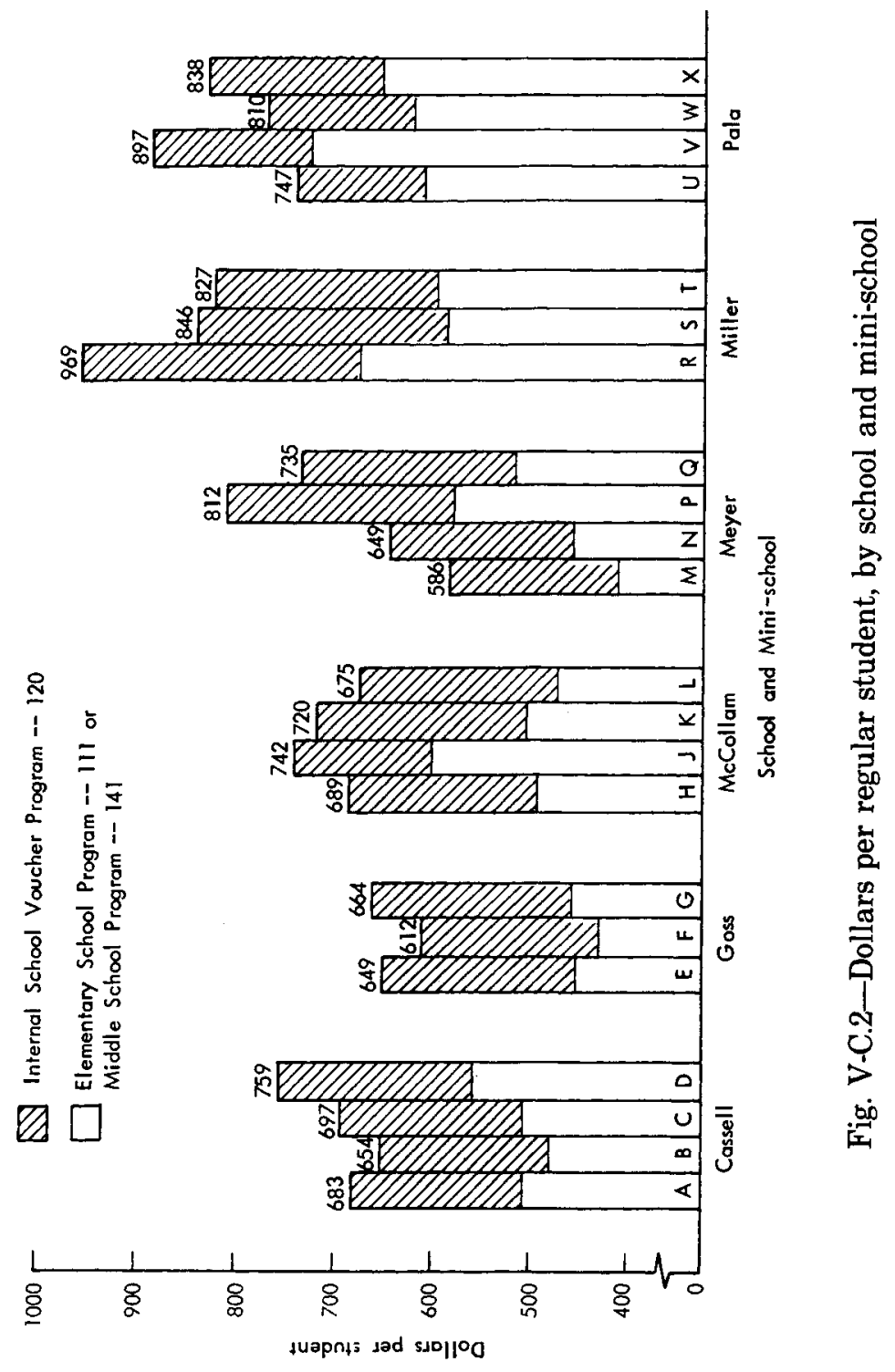


Table V-C. 3

SCHOOL AND MINI-SCHOOL BUDGET DATA, 1972-73

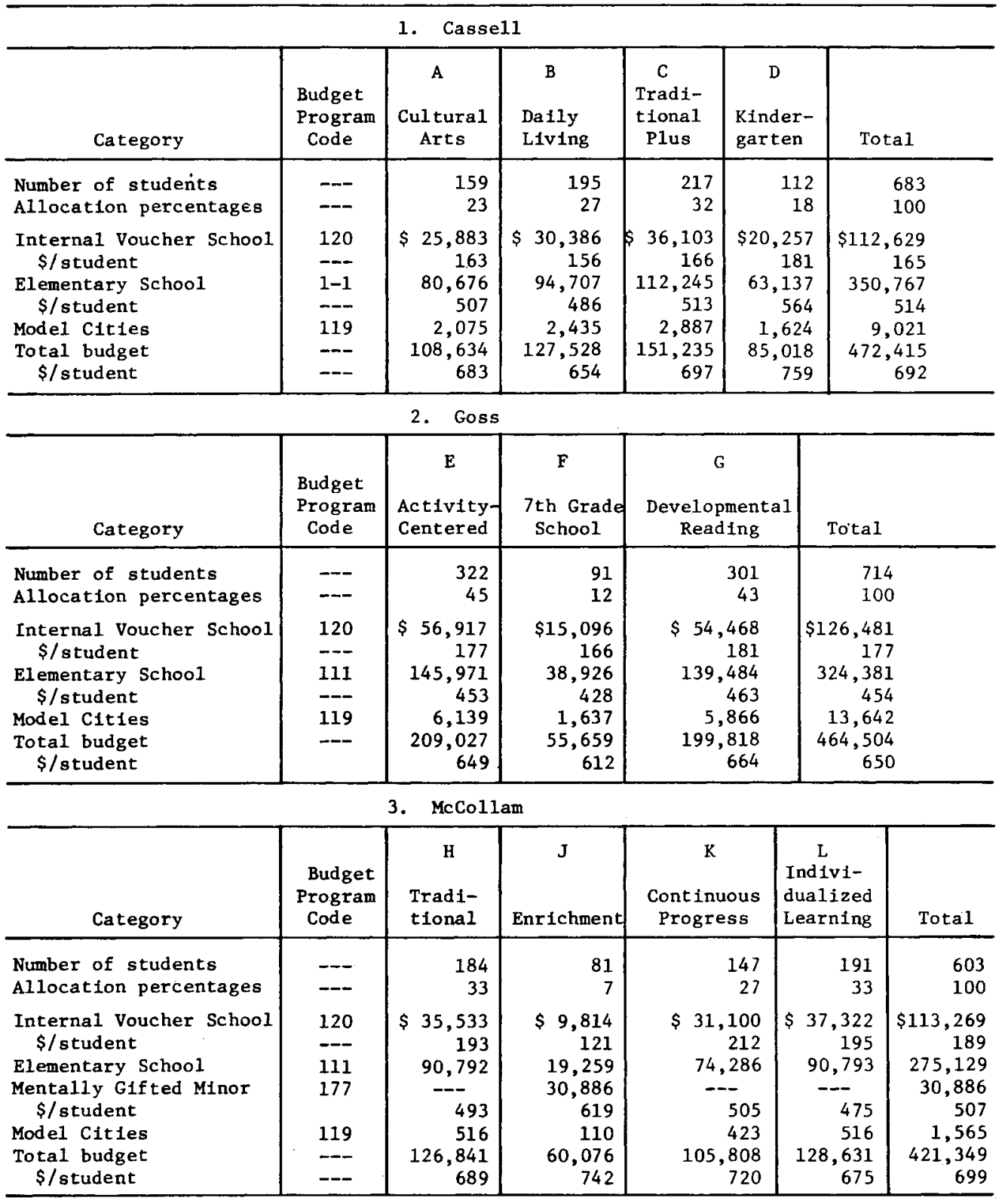


Table V-C.3--Continued

\begin{tabular}{|c|c|c|c|c|c|c|}
\hline \multicolumn{7}{|c|}{ 4. Meyer } \\
\hline Category & $\begin{array}{l}\text { Budget } \\
\text { Program } \\
\text { Code }\end{array}$ & $\begin{array}{c}\text { M } \\
\text { Basic } \\
\text { Skills }\end{array}$ & $\begin{array}{c}\mathrm{N} \\
\text { Sullivan } \\
\text { BRL }\end{array}$ & $\begin{array}{c}\text { P } \\
\text { Fine } \\
\text { Arts }\end{array}$ & $\begin{array}{c}Q \\
\text { School } \\
2000\end{array}$ & Tota1 \\
\hline $\begin{array}{l}\text { Number of students } \\
\text { Allocation percentages }\end{array}$ & -- & $\begin{array}{r}366 \\
43\end{array}$ & $\begin{array}{r}154 \\
20\end{array}$ & $\begin{array}{r}117 \\
19\end{array}$ & $\begin{array}{r}123 \\
18\end{array}$ & $\begin{array}{l}760 \\
100\end{array}$ \\
\hline $\begin{array}{l}\text { Internal Voucher School } \\
\text { \$/student } \\
\text { Elementary School } \\
\text { \$/student } \\
\text { Model Cities } \\
\text { Total budget } \\
\text { \$/student }\end{array}$ & $\begin{array}{l}120 \\
-111 \\
-\cdots- \\
119 \\
--\end{array}$ & \begin{tabular}{|r|}
$\$ 52,944$ \\
145 \\
152,907 \\
418 \\
8,621 \\
214,472 \\
586
\end{tabular} & $\begin{array}{r}\$ 24,825 \\
161 \\
71,119 \\
462 \\
4,010 \\
99,954 \\
649\end{array}$ & $\begin{array}{r}\$ 23,584 \\
202 \\
65,564 \\
577 \\
3,809 \\
94,956 \\
812\end{array}$ & $\begin{array}{r}\$ 22,748 \\
185 \\
64,007 \\
520 \\
3,608 \\
90,363 \\
735\end{array}$ & $\begin{array}{r}\$ 124,101 \\
163 \\
355,596 \\
468 \\
20,048 \\
499,745 \\
656\end{array}$ \\
\hline \multicolumn{7}{|c|}{ 5. Miller } \\
\hline Category & $\begin{array}{l}\text { Budget } \\
\text { Program } \\
\text { Code }\end{array}$ & $\begin{array}{c}\mathrm{R} \\
\text { Ind Ividual } \\
\text { Study }\end{array}$ & $\mid \begin{array}{c}\mathrm{S} \\
\text { Multi- } \\
\text { Cultural }\end{array}$ & $\begin{array}{c}T \\
\text { Academ } 1\end{array}$ & Tot & \\
\hline $\begin{array}{l}\text { Number of students } \\
\text { Allocation }\end{array}$ & -- & $\begin{array}{r}141 \\
33\end{array}$ & $\begin{array}{r}193 \\
39\end{array}$ & & $\begin{array}{l}35 \\
28\end{array}$ & $\begin{array}{l}469 \\
100\end{array}$ \\
\hline $\begin{array}{l}\text { Internal Voucher School } \\
\text { \$/student } \\
\text { Elementary School } \\
\text { \$/student } \\
\text { Model Cities } \\
\text { Total budget } \\
\text { \$/student }\end{array}$ & $\begin{array}{l}120 \\
--- \\
111 \\
--- \\
119 \\
---\end{array}$ & $\begin{array}{r}\$ 36,537 \\
259 \\
96,302 \\
683 \\
3,838 \\
136,677 \\
969\end{array}$ & $\begin{array}{r}\$ 44,882 \\
234 \\
113,812 \\
590 \\
4,535 \\
163,229 \\
846\end{array}$ & $\begin{array}{r}\$ 26,63 \\
19 \\
81,71 \\
60 \\
3,25 \\
111,60 \\
82\end{array}$ & \begin{tabular}{l|r}
33 & $\$ 108$, \\
97 & \\
11 & 291, \\
05 & \\
56 & 11, \\
00 & 411, \\
27 &
\end{tabular} & $\begin{array}{l}052 \\
230 \\
825 \\
622 \\
629 \\
506 \\
877\end{array}$ \\
\hline \multicolumn{7}{|c|}{ 6. Pala } \\
\hline Category & $\begin{array}{l}\text { Budget } \\
\text { Program } \\
\text { Code }\end{array}$ & $\begin{array}{c}\text { U } \\
\text { Three R's } \\
\text { Plus }\end{array}$ & $\begin{array}{c}V \\
\text { Creative } \\
\text { Arts }\end{array}$ & $\begin{array}{l}\text { W } \\
\text { Fine } \\
\text { Arts }\end{array}$ & $\begin{array}{c}\mathrm{x} \\
\text { Math/ } \\
\text { Sclence }\end{array}$ & Total \\
\hline $\begin{array}{l}\text { Number of students } \\
\text { Allocation percentages }\end{array}$ & --- & $\begin{array}{r}211 \\
32\end{array}$ & $\begin{array}{r}217 \\
39\end{array}$ & $\begin{array}{r}111 \\
18\end{array}$ & $\begin{array}{l}68 \\
11\end{array}$ & $\begin{array}{l}607 \\
100\end{array}$ \\
\hline $\begin{array}{l}\text { Internal Voucher School } \\
\text { \$/student } \\
\text { Middle School } \\
\text { \$/student } \\
\text { Other Middle School } \\
\text { \$/student } \\
\text { Total budget } \\
\text { \$/student }\end{array}$ & $\begin{array}{c}120 \\
\overline{141} \\
--- \\
142-151 \\
--- \\
---\end{array}$ & $\begin{array}{r}\$ 27,271 \\
129 \\
74,773 \\
354 \\
55,606 \\
264 \\
157,651 \\
747\end{array}$ & \begin{tabular}{|r}
$\$ 35,792$ \\
165 \\
91,129 \\
420 \\
67,771 \\
312 \\
194,692 \\
897
\end{tabular} & $\begin{array}{r}\$ 16,521 \\
149 \\
42,060 \\
379 \\
31,279 \\
282 \\
89,860 \\
810\end{array}$ & $\begin{array}{r}\$ 12,191 \\
179 \\
25,703 \\
378 \\
19,114 \\
281 \\
57,008 \\
838\end{array}$ & \begin{tabular}{|r}
$\$ 91,775$ \\
151 \\
233,665 \\
385 \\
173,771 \\
286 \\
499,211 \\
822
\end{tabular} \\
\hline
\end{tabular}




\section{COMPARABLE MINI-SCHOOL INSTRUCTIONAL COST PER CLASSROOM}

Inevitably, a cost per student for each of the twenty-two mini-schools will be calculated by various people for different purposes. One of the most important purposes, perhaps, would be to get an idea of the cost of a particular combination of resources that seems to work. The twenty-two mini-schools of the 1972-73 voucher demonstration do represent alternative ways to provide elementary education. The expectation of voucher proponents is that in the long-run, one of the outcomes may well be a more effective education. If this should prove to be true, then the next questions to be answered are: "Can the alternative be afforded?"; "How does the cost of the more effective alternative compare with other alternatives?"

If budget data are used, the cost will be biased by such things as the size of the mini-school and the actual teacher salaries. The objective here is to explore the development of another measure-the instructional cost per classroom. That cost, estimated for each mini-school, provides a more useful picture of alternative levels of resource-use.

As defined, the instructional cost per classroom includes classroom teacher, resource teacher, and instructional aide salaries (with fringe benefits, as applicable), instructional materials, equipment and supplies (consumables), and the cost of field trips. It does not include a prorated share of the noninstructional expenses of running the school, such as the principal's salary, the secretary 's salary, clerical services, or custodial services. The exclusion of these expenses is an important feature of the measure; the instructional cost per classroom becomes a measure of the resources involved in the educational process at the classroom level. This assumes, of course, homogeneity of classroom resource-use within the mini-school.

Another feature of the measure is its use of across-the-board average salary figures for the staff involved. This avoids differences among mini-schools that are attributable solely to salary differentials rather than to resource mix or levels of use. The resulting instructional cost per classroom provides a more equitable basis for the mini-school program cost comparisons that are bound to occur.

The instructional cost per classroom can also be used as a basis for calculating a cost per student for the mini-school by assuming thirty students for each classroom. The cost per student derived in this manner is insensitive to minor variations in the number of students in the mini-school (its size) and serves as an index in comparing the different mini-schools. In this way, the circularity implicit in the conventional practice of estimating the cost per student can be avoided. Recall the manner in which the principal's salary, for example, was allocated to the minischools of the host school. In the case of teacher salaries, the total is divided by the number of students in estimating the cost per student. In the real world, if the teacher salary total is $\$ 91,997$, then the cost per student for, say, 224 students is $\$ 411$-a figure that changes as the enrollment increases up to the point where an additional teacher is needed. If the enrollment drops to 203, the cost per student for teachers is $\$ 453$ but an increase to 245 students would probably necessitate adding a teacher. The class size would be too high, in light of state requirements, at 35 students per classroom, but the cost per student would be a much lower $\$ 375$. Number-juggling aside, the point is that the use of the instructional cost per classroom and a constant 30 students for each classroom provides an index-like measure when the cost per student is used as a basis for comparing mini-schools.

The instructional cost for each mini-school, the instructional cost per classroom, and the cost per student are all based on the cost of items the mini-school uses in providing its program. It is, in essence, the cost of the package of instructional 
services unique to a particular mini-school. As mentioned earlier, the noninstructional expenses of running the school site are not included. Neither is the cost of space. Excluding the cost of space deserves a separate discussion.

The objective is to measure the resources that make one mini-school different from another in carrying out an instructional program. Only the public school system was involved in the 1972-73 school year, and the mini-schools represented only a reorganization of the existing resources of the district. All students were provided with "space" on a uniform basis. There are no significant variations in the manner in which the mini-schools use space. Including the cost of space in the estimate of a mini-school's instructional cost per classroom does not change the relative ranking of a mini-school. In an accounting sense, however, the cost of space would be important and, as private schools entered the voucher demonstration, the cost of space would be a factor in assessing the resource-use characteristics of alternative mini-schools.

In developing the estimates of the instructional cost per classroom, it is further assumed that all classrooms are furnished in much the same way and that a similar package of basic instructional materials is provided for each classroom. These assumptions seem to be valid except for the McCollam Enrichment mini-school. This mini-school is also supported by state funds under the Mentally Gifted Minor program; in addition, budgetary data show a higher per student allocation for some of the central district services and supplies.

The estimate provided here for the Enrichment mini-school may be low because actual resources are used in developing the estimate and because this mini-school had very few students eligible for compensatory vouchers. This mini-school faculty also refused to provide any information about the materials being used, about field trips taken, or about other details of their operation. The Enrichment mini-school faculty's claim to the title of "the cheapest mini-school" may be true. There is no reasonable basis for increasing the estimate. It could be conjectured, however, that the Enrichment classrooms started with more materials and equipment than did the other mini-school classrooms. They were identified as the classrooms for the districtdesignated mentally gifted minors in the years before the voucher demonstration.

The details of the estimated instructional cost per classroom for each minischool, shown in Table V-C.4, provide supporting information about the differences in resource-use among the mini-schools.

In estimating the instructional cost per classroom, aide-use is calculated in 3 -hour equivalents. For example, a 6 -hour aide is the equivalent of two 3-hour aides. This technique is necessary and logical in developing an index measure, or comparable cost estimate, for the mini-schools. In the financial context of the district, it is not an acceptable technique because the 3-hour aide does not receive fringe benefits but the 6-hour aide does. Assuming a fringe benefit package of twenty percent of base salary, two 3-hour aides can be employed for twenty percent less than one six-hour aide. This example serves to highlight the non-accounting/budgeting nature of the instructional cost per classroom estimates. The estimates are intended as comparable measures of resource-use by the various mini-schools, and by design do not reflect the realities of financial accountability.

The instructional cost per classroom and cost per student for each of the minischools are shown in Table V-C.5 and Fig. V-C.3. The instructional cost per classroom ranged from a low of $\$ 17,312$ for the McCollam Enrichment mini-school to a high of $\$ 22,315$ for the Pala Fine Arts mini-school. When only the elementary grades (K-6) are considered, the Meyer Sullivan-BRL mini-school with $\$ 21,874$ has the highest instructional cost per classroom. The instructional cost per classroom pro- 
Table V-C.4

COMPARABLE MINI-SCHOOL INSTRUCTIONAL COSTS

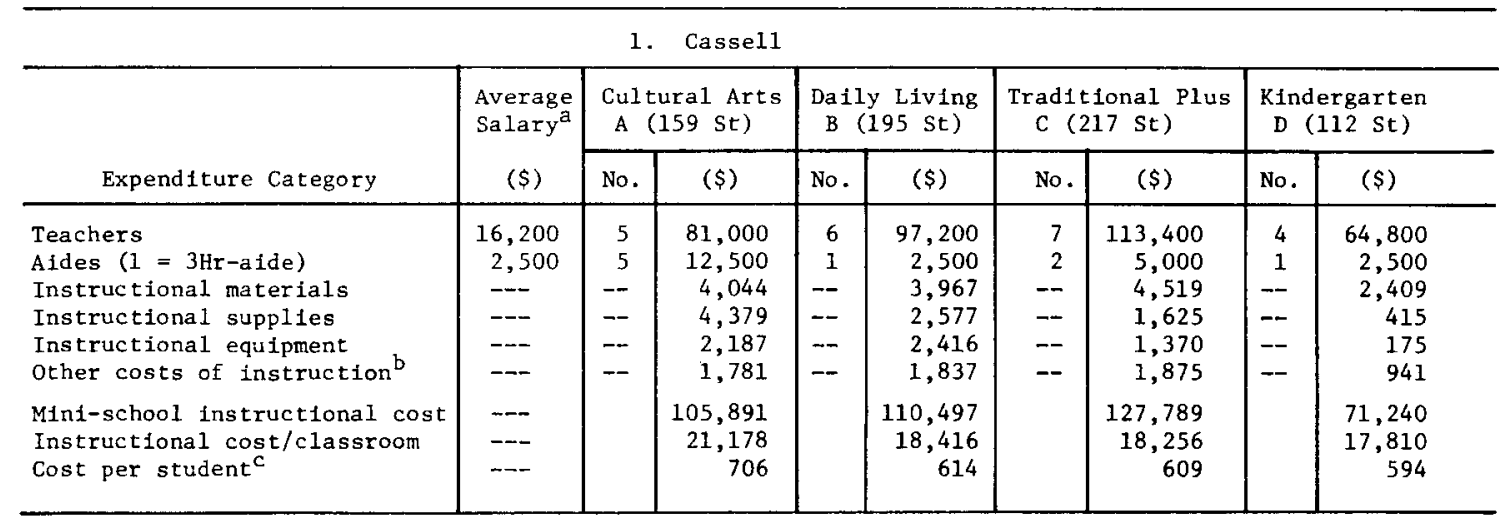

2. Goss

\begin{tabular}{|c|c|c|c|c|c|c|c|}
\hline \multirow[b]{2}{*}{ Expenditure Category } & \multirow{2}{*}{$\begin{array}{c}\text { Average } \\
\text { Salarya } \\
(\$)\end{array}$} & \multicolumn{2}{|c|}{$\begin{array}{c}\text { Activity-Centered } \\
\text { E }(322 \mathrm{St})\end{array}$} & \multicolumn{2}{|c|}{$\begin{array}{c}7 \text { th Grade School } \\
\text { F }(91 \mathrm{St})\end{array}$} & \multicolumn{2}{|c|}{$\begin{array}{c}\text { Develop. Reading } \\
\text { G (301 St) }\end{array}$} \\
\hline & & No. & $(\$)$ & No. & $(\$)$ & No. & $(\$)$ \\
\hline $\begin{array}{l}\text { Teachers } \\
\text { Aides }(1=3 \mathrm{Hr} \text {-aide) } \\
\text { Instructional materials } \\
\text { Instructional supplies } \\
\text { Instructional equipment } \\
\text { other costs of instruction }\end{array}$ & $\begin{array}{c}16,200 \\
2,500 \\
--- \\
--- \\
--- \\
---\end{array}$ & $\begin{array}{r}10 \\
7 \\
-- \\
-- \\
-- \\
--\end{array}$ & $\begin{array}{r}162,000 \\
17,500 \\
4,736 \\
3,490 \\
3,952 \\
6,410\end{array}$ & $\begin{array}{r}3 \\
2 \\
-- \\
-- \\
-- \\
--\end{array}$ & $\begin{array}{r}48,600 \\
5,000 \\
1,147 \\
535 \\
561 \\
4,373\end{array}$ & $\begin{array}{r}9 \\
5 \\
-- \\
-- \\
--\end{array}$ & $\begin{array}{r}145,800 \\
12,500 \\
3,464 \\
1,837 \\
2,665 \\
5,590\end{array}$ \\
\hline $\begin{array}{l}\text { Mini-school Instructional cost } \\
\text { Instructional cost/classroom } \\
\text { Cost per student }\end{array}$ & $\begin{array}{l}--- \\
--- \\
---\end{array}$ & & $\begin{array}{r}198,088 \\
19,809 \\
660\end{array}$ & & $\begin{array}{r}60,216 \\
20,072 \\
669\end{array}$ & & $\begin{array}{r}171,856 \\
19,095 \\
637\end{array}$ \\
\hline
\end{tabular}

3. McCollam

\begin{tabular}{|c|c|c|c|c|c|c|c|c|c|}
\hline \multirow[b]{2}{*}{ Expenditure Category } & \multirow{2}{*}{$\begin{array}{c}\text { Average } \\
\text { Salary } \\
(\$)\end{array}$} & \multicolumn{2}{|c|}{$\begin{array}{l}\text { Traditional } \\
\text { H (184 St) }\end{array}$} & \multicolumn{2}{|c|}{$\begin{array}{l}\text { Enrichment } \\
J(81 \mathrm{St})\end{array}$} & \multicolumn{2}{|c|}{$\begin{array}{l}\text { Continuous Progress } \\
\text { K (147 St) }\end{array}$} & \multicolumn{2}{|c|}{$\begin{array}{l}\text { Indiv. Learning } \\
\mathrm{L}(191 \mathrm{St})\end{array}$} \\
\hline & & No. & (\$) & No. & $(\$)$ & No. & (\$) & No. & (\$) \\
\hline $\begin{array}{l}\text { Teachers } \\
\text { Aides }(1=3 \mathrm{Hr} \text {-aide) } \\
\text { Instructional materials } \\
\text { Instructional supplies } \\
\text { Instructional equipment } \\
\text { Other costs of instruction }\end{array}$ & $\begin{array}{c}16,200 \\
2,500 \\
--- \\
-- \\
-- \\
--\end{array}$ & $\begin{array}{r}6 \\
2 \\
-- \\
-- \\
--\end{array}$ & $\begin{array}{r}97,200 \\
5,000 \\
4,400 \\
666 \\
2,767 \\
656\end{array}$ & $\begin{array}{l}3 \\
-- \\
-- \\
-- \\
-- \\
--\end{array}$ & $\begin{array}{r}48,600 \\
-- \\
2,636 \\
160 \\
399 \\
141\end{array}$ & $\begin{array}{l}5.5 \\
3.3 \\
-- \\
-- \\
-- \\
--\end{array}$ & $\begin{array}{r}89,100 \\
8,250 \\
3,127 \\
941 \\
990 \\
547\end{array}$ & $\begin{array}{r}6 \\
1 \\
-- \\
-- \\
-- \\
--\end{array}$ & $\begin{array}{r}97,200 \\
2,500 \\
11,623 \\
772 \\
4,462 \\
656\end{array}$ \\
\hline $\begin{array}{l}\text { Mini-school instructional cost } \\
\text { Instructional cost/classroom } \\
\text { Cost per student }\end{array}$ & $\begin{array}{l}--- \\
---\end{array}$ & & $\begin{array}{r}110,689 \\
18,448 \\
615\end{array}$ & & $\begin{array}{r}51,936 \\
17,312 \\
577\end{array}$ & & $\begin{array}{r}102,955 \\
20,591 \\
686\end{array}$ & & $\begin{array}{r}117,213 \\
19,536 \\
651\end{array}$ \\
\hline
\end{tabular}


Table V-C.4--Continued

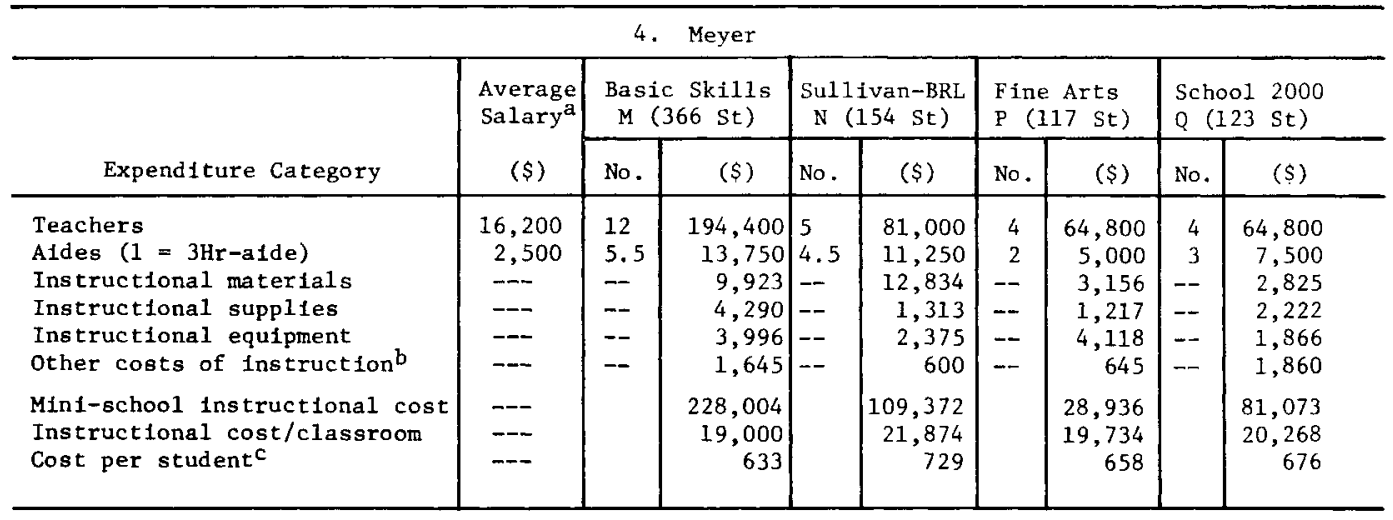

5. Miller

\begin{tabular}{|c|c|c|c|c|c|c|c|}
\hline \multirow[b]{2}{*}{ Expenditure Category } & \multirow{2}{*}{$\begin{array}{l}\text { Average } \\
\text { Salarya } \\
\text { (\$) }\end{array}$} & \multicolumn{2}{|c|}{$\begin{array}{l}\text { Individual. Study } \\
\quad \mathrm{R} \text { (14I St) }\end{array}$} & \multicolumn{2}{|c|}{$\begin{array}{l}\text { Multi-Cultural } \\
\text { S (193 St) }\end{array}$} & \multicolumn{2}{|c|}{$\begin{array}{l}\text { Academic Skills } \\
T(135 \mathrm{St})\end{array}$} \\
\hline & & No. & (\$) & No. & $(\$)$ & No. & (\$) \\
\hline $\begin{array}{l}\text { Teachers } \\
\text { Aides }(1=3 \mathrm{Hr} \text {-aide) } \\
\text { Instructional materials } \\
\text { Instructional supplies } \\
\text { Instructional equipment } \\
\text { Other costs of instructionb }\end{array}$ & $\begin{array}{c}16,200 \\
2,500 \\
-- \\
-- \\
--\end{array}$ & $\begin{array}{r}6 \\
2 \\
-- \\
-- \\
-- \\
--\end{array}$ & $\begin{array}{r}97,200 \\
5,000 \\
1,419 \\
143 \\
2,096 \\
750\end{array}$ & $\begin{array}{l}7 \\
4.5 \\
-- \\
-- \\
-- \\
--\end{array}$ & $\begin{array}{r}113,400 \\
11,250 \\
3,128 \\
1,745 \\
1,568 \\
2,000\end{array}$ & $\begin{array}{r}5 \\
2 \\
-- \\
-- \\
-- \\
--\end{array}$ & $\begin{array}{r}81,000 \\
5,000 \\
1,061 \\
940 \\
368 \\
300\end{array}$ \\
\hline $\begin{array}{l}\text { Mint-school instructional cost } \\
\text { Instructional cost/classroom } \\
\text { Cost per student }{ }^{c}\end{array}$ & --- & & $\begin{array}{r}106,608 \\
17,768 \\
592\end{array}$ & & $\begin{array}{r}133,091 \\
19,013 \\
634\end{array}$ & & $\begin{array}{r}88,669 \\
16,200 \\
540\end{array}$ \\
\hline
\end{tabular}

6. Pala

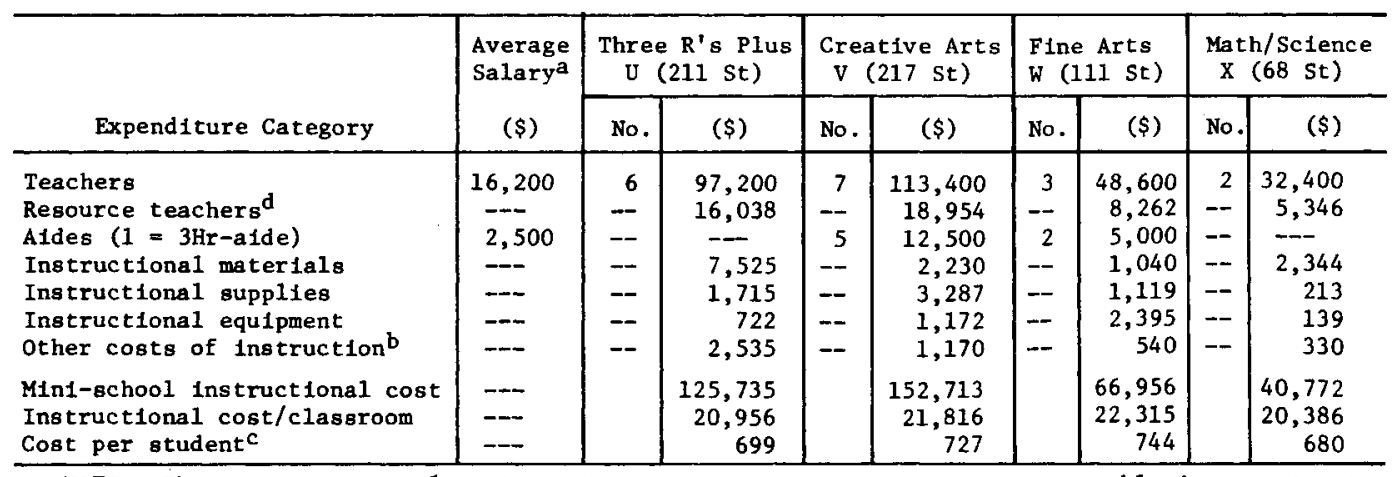

NOTE: These are not actual costs. The cost per student, based on a comparable instructional cost per classroom and 30 students in a classroom, is estimated to provide an equitable measure of a mint-school's use of resources.

ancludes fringe benefits.

b Includes cost of field trips and contract instructional services.

${ }^{c}$ Based on 30 students per classroom.

dPro-rated share of the Resource Center's teachers. 
Table V-C. 5

MINI-SCHOOL INSTRUCTIONAL COSTS PER CLASSROOM, COST PER STUDENT, AND DOLLAR DIFFERENCE WITHIN HOST-SCHOOL

\begin{tabular}{|c|c|c|c|}
\hline Mini-school & $\begin{array}{l}\text { Instructional } \\
\text { Cost per } \\
\text { Classroom }\end{array}$ & $\begin{array}{l}\text { Instructional } \\
\text { Cost per } \\
\text { Student }^{\mathrm{a}}\end{array}$ & $\begin{array}{l}\text { Difference } \\
\text { Between } \\
\text { Highest and } \\
\text { Lowest Cost } \\
\text { Mini-school }\end{array}$ \\
\hline $\begin{array}{l}\text { Cassezz } \\
\text { Cultural Arts } \\
\text { Daily Living } \\
\text { Traditional Plus } \\
\text { Kindergarten }\end{array}$ & $\begin{array}{r}\$ 21,178 \\
18,416 \\
18,256 \\
17,810\end{array}$ & $\begin{array}{r}\$ 706 \\
614 \\
609 \\
594\end{array}$ & $\$ 97^{b}$ \\
\hline $\begin{array}{l}\text { Goss } \\
\text { Activity-Centered } \\
7 \text { th Grade School } \\
\text { Developmental Reading }\end{array}$ & $\begin{array}{r}\$ 19,809 \\
20,072 \\
19,095\end{array}$ & $\begin{array}{r}\$ 660 \\
669 \\
637\end{array}$ & $\$ 82$ \\
\hline $\begin{array}{l}\text { MeColzam } \\
\text { Traditional } \\
\text { Enrichment } \\
\text { Continuous Progress } \\
\text { Individualized Learning }\end{array}$ & $\begin{array}{r}\$ 18,448 \\
17,312 \\
20,591 \\
19,536\end{array}$ & $\begin{array}{r}\$ 615 \\
577 \\
686 \\
651\end{array}$ & $\$ 109$ \\
\hline $\begin{array}{l}\text { Meyer } \\
\text { Basic Skills } \\
\text { Sullivan BRL } \\
\text { Fine Arts } \\
\text { School } 2000\end{array}$ & $\begin{array}{r}\$ 19,000 \\
21,874 \\
19,734 \\
20,268\end{array}$ & $\begin{array}{r}\$ 633 \\
729 \\
658 \\
676\end{array}$ & $\$ 96$ \\
\hline $\begin{array}{l}\text { Mizzer } \\
\text { Individual Study } \\
\text { Multicultural } \\
\text { Academic Skflls }\end{array}$ & $\begin{array}{r}\$ 17,768 \\
19,013 \\
17,734\end{array}$ & $\begin{array}{r}\$ 592 \\
634 \\
591\end{array}$ & $\$ 43$ \\
\hline $\begin{array}{l}\text { Pala } \\
\text { Three R's Plus } \\
\text { Creative Arts } \\
\text { Fine Arts } \\
\text { Math-Sclence }\end{array}$ & $\begin{array}{r}\$ 20,956 \\
21,816 \\
22,315 \\
20,386\end{array}$ & $\begin{array}{r}\$ 699 \\
727 \\
744 \\
680\end{array}$ & $\$ 64$ \\
\hline $\begin{array}{l}\text { NOTE: These are not a } \\
\text { on a comparable instruct1 } \\
\text { a classroom, is estimated } \\
\text { school's use of resources } \\
\text { a Based on } 30 \text { students } \\
\text { b The Kindergarten mint } \\
\text { differences. }\end{array}$ & $\begin{array}{l}\text { lal costs. Th } \\
1 \text { cost per } c \\
\text { provide an } \\
\text { a classroom, } \\
\text { hool is excl. }\end{array}$ & $\begin{array}{l}\text { cost per st } \\
\text { ssroom and } 3 \\
\text { uitable meas } \\
\text { ot on actual } \\
\text { ed from this }\end{array}$ & $\begin{array}{l}\text { nt, based } \\
\text { tudents in } \\
\text { of a mini- } \\
\text { rollment. } \\
\text { inge of }\end{array}$ \\
\hline
\end{tabular}

vides, on an equitable and supportable basis, additional information useful in looking at the differences among mini-schools.

The instructional cost per student, on a basis of 30 students in a classroom, provides insights into the differences in resource-use among the mini-schools within each school. The widest variation was within McCollam, where the highest minischool spent $\$ 109$ more than the lowest mini-school. Variations within Cassell and Meyer were also substantial. The interesting point is that all of the elementary grade mini-schools are providing elementary education but the cost per student ranges from $\$ 577$ to $\$ 729$, a variation of about $\$ 150$ in the cost of their combination of resources. In a district of 12,000 elementary students this could mean an expendi- 


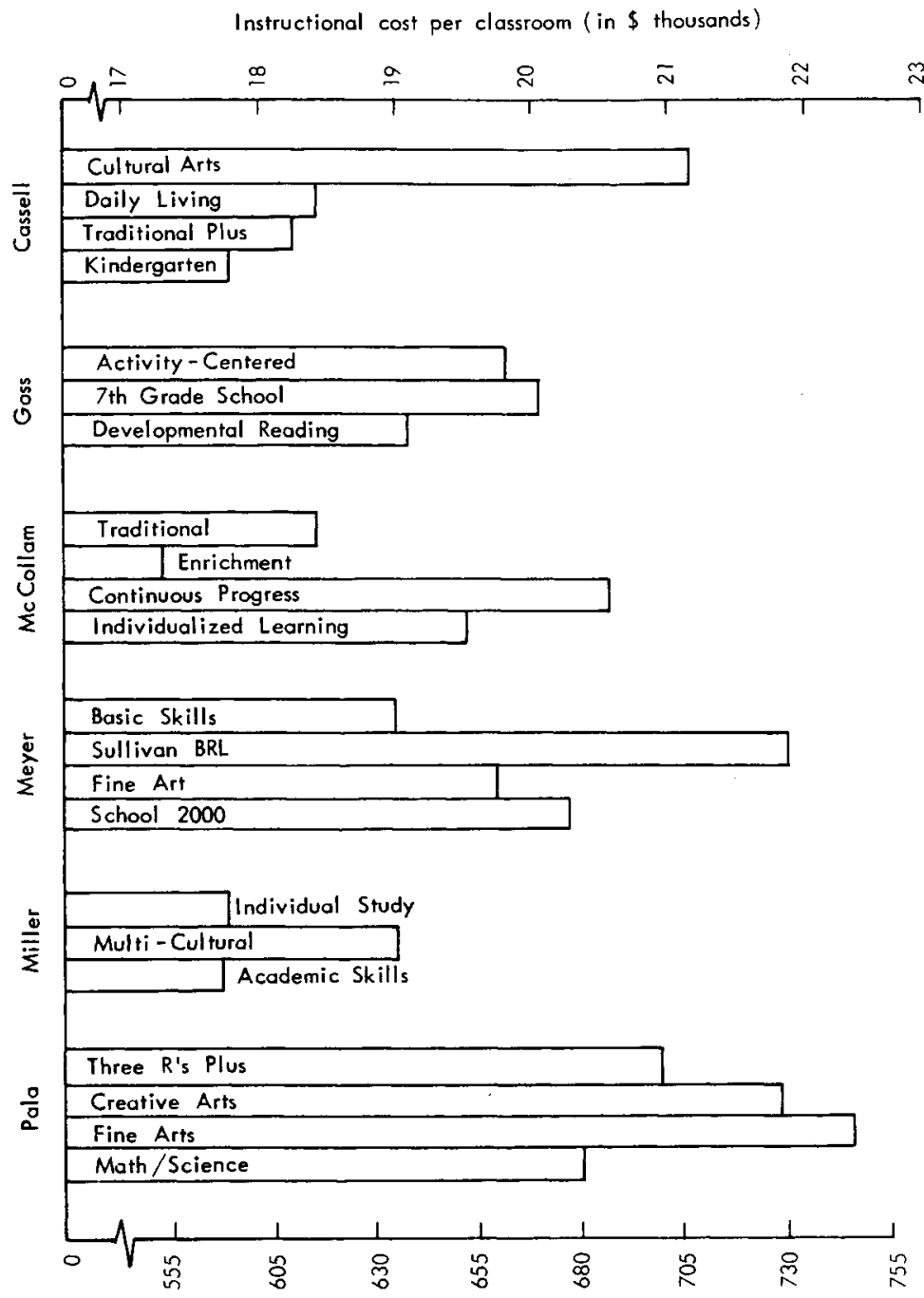

Instructional cost (in \$) per student (30 students per classroom)

Fig. V-C.3 - Comparable mini-school instructional cost per classroom and instructional cost per student

ture difference of $\$ 1.8$ million a year. This assumes, of course, that the outcomes of the particular combination of resources are acceptable. The differences among the mini-schools that are identified as a result of estimating the comparable instructional cost per classroom or student serve to signal outstanding mini-schools for a more detailed investigation of their instructional strategy. 


\section{Appendix VI-A \\ COMMUNITY OPINION SURVEY}

This is the form of the survey questionnaire which was administered to voucher parents. Other samples received slightly different versions of this questionnaire.

Field Research Corporation

145 Montgomery Street

389-002

Sar Francisco, California

WHITE FORM: TO BE USED WHEN
INTERVIEWING SPECIFIC PARENTS
K-8 IN THE DEMONSTRATION AREA

As you may know, interviews are being made among a random sample of parerits who have children in the Alum Rock public schools, and I'd like to speas to (NAME FROM FRONT PAGE) if I may, please.

IF DESIGNATED PERSON NOT AT HOME, FIND OUT BEST TIME TO CALL BACK AND MAKE AN APPOINTMENT TO RETURN THEM.

Call back on:
(day)
(time)

CONTINUE WITH PROPER RESPONDENT

The reason for the survey is to find out what people in this area think of the schools here and the kind of education they feel that children in this district are receiving.

There are no "right" or "wrong" answers to any of the questions -- we just want to know what you think. My company is completely independent from the school district, and no one at the schools will ever know what you tell me. Your answers 11 be kept strictly confidential.

NOW PROCEED WITH INTERVIEW.

Time began: $\quad \mathrm{AM}$


1. A. How many children do you have in these schools?

IF ONE, SAY: Is that a boy or a girl? RECORD ON

LINE NO. 1 BELOW. What is (his/her)

name? RECORD ON LINE NO. 1. ASK

Q. 3 TO 6 BELOW THEN GO TO NEXT PAGF。

IF MORE THAN ONE, SAY: I would like to talk to you about what grades your children are in, what schools they go to, what you think of those schools and so on. To do this, let's start with the oldest child you have in school this year, who would that be? ASK QUESTIONS 2 THROUGH 6 FOR THAT CHILD. THEN SAY: "Now, what about the next oldest?" REPEAT UNTIL YOU HAVE LISTED ALL OF THE CHILDREN IN SCHOOLS SHOWN ON CARD AND ASK QUESTIONS 2 THROUGH 6 FOR EACH.

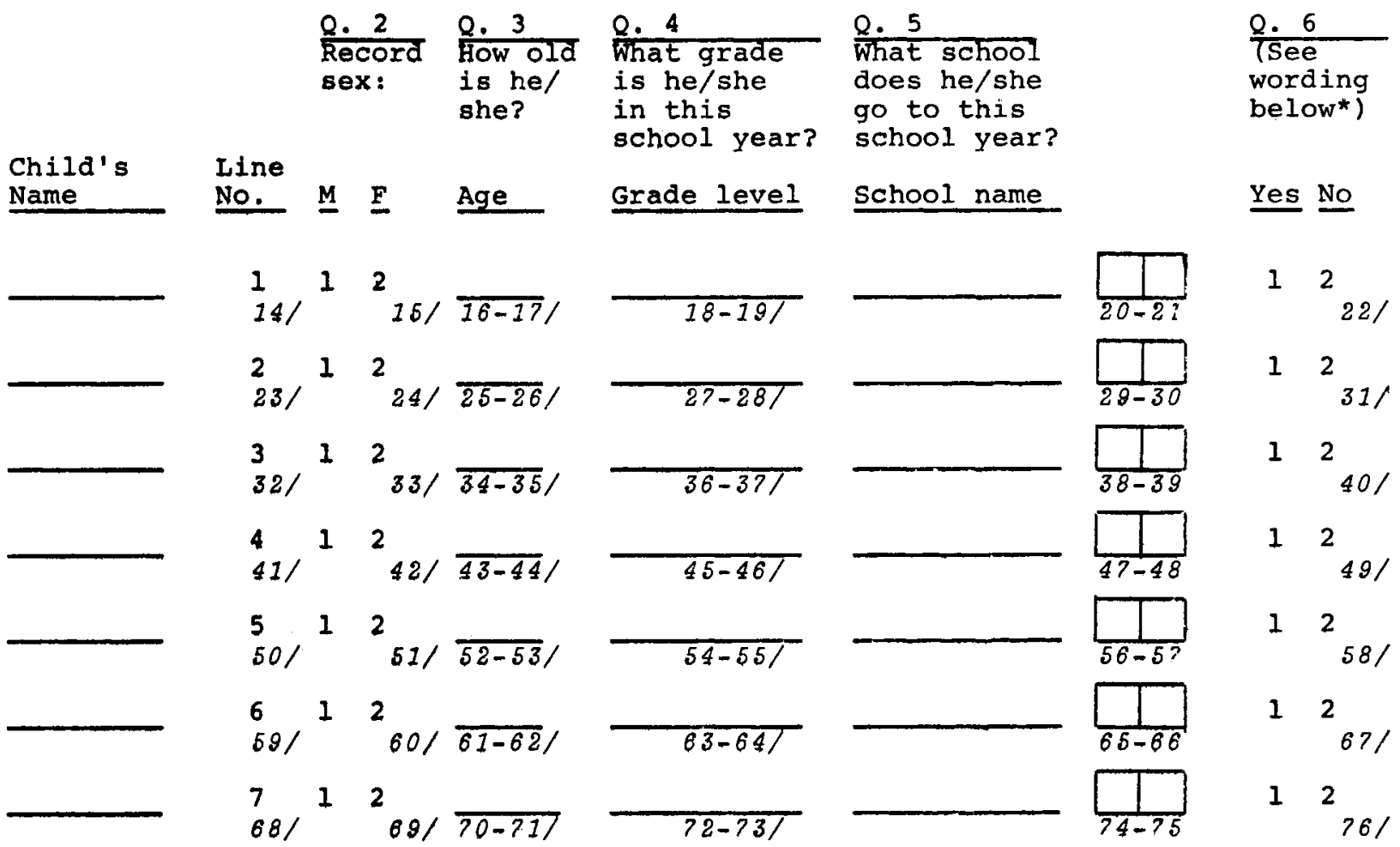

Ques. 6: Did he/she attend a nursery school or any of pre-school programs such as Head Start? 


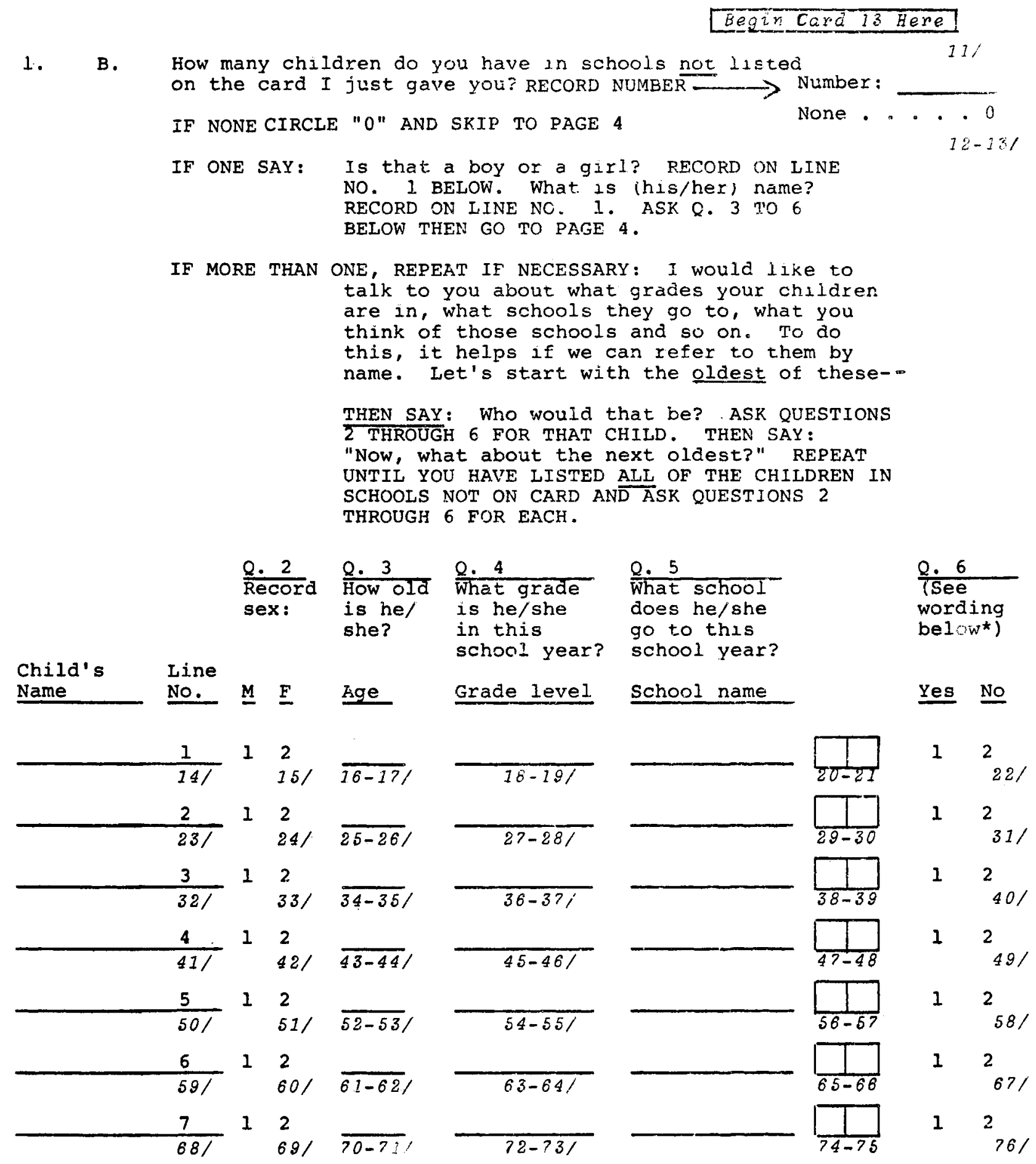

Ques. 6: Did he/she attend a nursery school or iny of pre-school programs such as Head Start? 
Now I'd like to talk to you about how your (child is/children are) getting along in school. We are especially interested in children in grades from kindergarten through 8 th.

\section{INTERVIEWER :}

RECORD NUMBER OF CHILDREN FROM Q. I.A. ON PAGE 2 HERE:

IF ONE CHILD, SKIP TO NEXT PAGE

IF MORF, THAN ONE, CONTINUF AS FOLLOWS:

I have a chart here which tells me which of your children in grades K- 8 that go to public schools I should like to ask about first. It's like pulling numbers out of a hat.

NOW LOOK ACROSS THE CHART BELOW AND FTND THE NUM $\overline{\text { ATER }}$

OF CHILDREN THAT YOU JUST RECORDED ABOVE FROM Q.I.A.

ON PAGE 2. UNDERNEATH IT YOU WILL FIND THE IINE

NUMBER ON PAGE 2 OF THE CHILD ABOUT WHOM VOU WILL

ASK Q. 7-24

\section{LABEL \#2}

$12-18$

RECORD LINE NO. HERE OF SELECTED CHILD

LOOK ON PAGF 2 FOR THE SELECTED CHILD'S 197

NAME SO YOU CAN USE IT IN Q. 7-24

RECORD NAME OF CHILD HERE 
All right, let's start with (NAME OF CHILD).

7. Do you think (CHILD) likes school this year most of the time, some of the time, or almost none of the time?

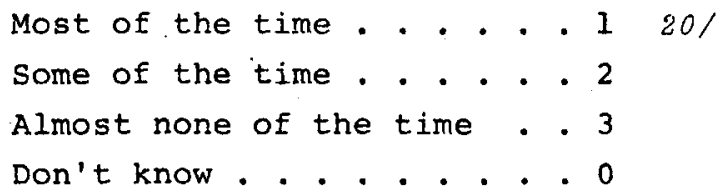

Let's see, (CHILD) goes to (NAME OF SCHOOL). (INTERVIEWER: LOOK ON PAGE 2 FOR NAME OF SCHOOL THIS CHILD ATTENDS.)

8. In general, do you think that the education (CHILD) is getting at (SCHOOL) is very good, good, fair, or poor?

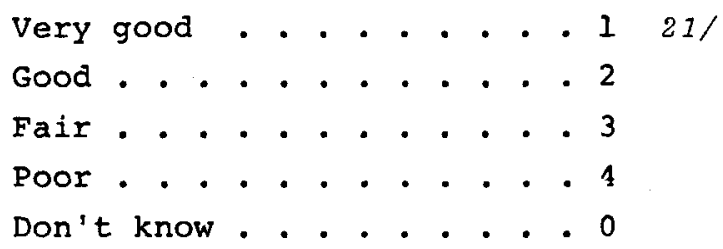

9. Do you think the principal is doing a very good job, a good job, a fair job, or a poor job?

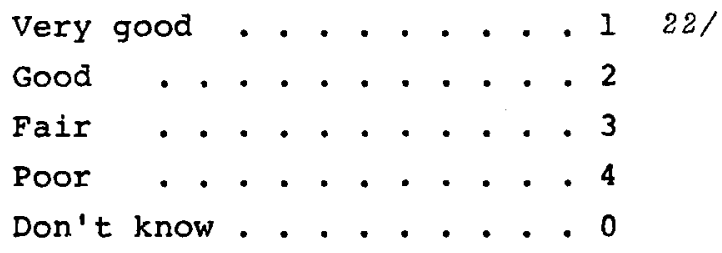

10. Do you think his/her teacher is doing a very good job, a good job, a fair job, or a very poor job?

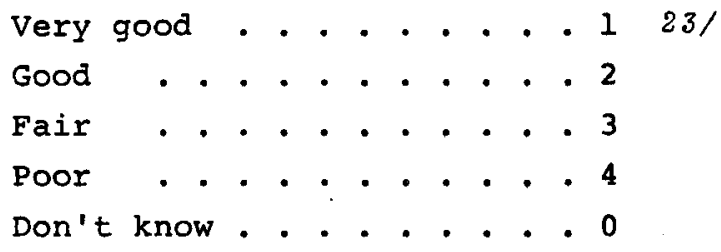

11. Does (CHILD) like (his/her) (homeroom) teacher a lot, somewhat, a little, or not at all?

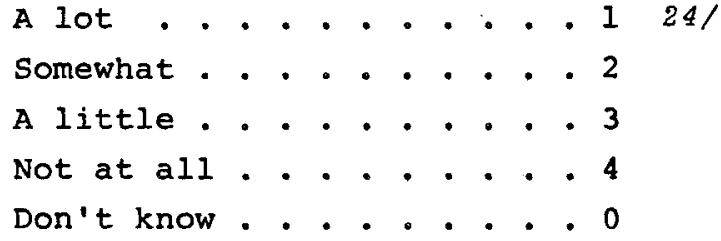


12. So far this school year, how do you think (CHILe) is doing in (his/her) school work? Is (he/she) doing very well, fairly well, not too we'l, or very poorly?

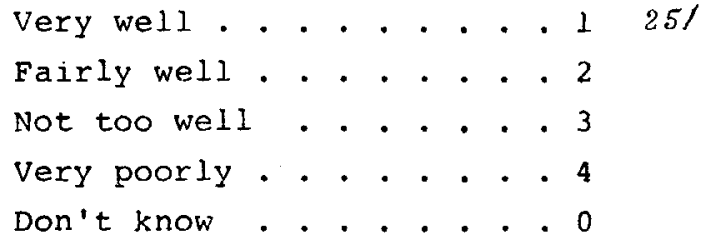

17. Has (CHILD) ever gone to another elementary school besides the one (he/she) attends now?

$$
\begin{aligned}
& \text { Yes (ASK A AND B) . . . . . } 1 \text { 33/ } \\
& \text { No }, . ., \cdot ., ., 2
\end{aligned}
$$

\section{IF YES:}

A. How many other schools has (he/she) gone to in total?

\section{(No. of other schools)}

B. When did (CHILD) start going to the school he attends now-this school year, during the last school year (1971-72), or before that?

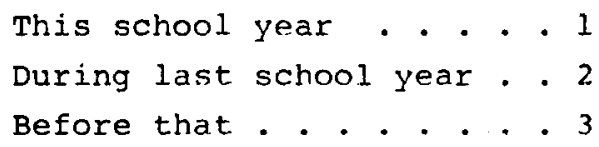

18. A. How many years of school would you personally like (CHILD) to complete? READ CATEGORIES AND CODE IN COL. A.

B. How many years of school do you think (CHILD) will actually complete? READ CATEGORIES AND CODE IN COL. B.

Some high school . . . . . . . . .

Graduate from high school . . . . . . 2

Some college, technical, business or trade school . . . . . . . . . 3

Graduate from college . . . . . . . 4

Post graduate or professional school . 5

Don't know . . . . . . . . . . . . 0

\begin{tabular}{l|l}
\hline$A$ & $B$ \\
\hline 377 & $38 /$ \\
1 & 1 \\
2 & 2 \\
3 & 3 \\
4 & 4 \\
5 & 5 \\
0 & 0
\end{tabular}


23. Everything considered, how satusfied are you with how (ChIID) is doing in school these days--very satisfied, somewhat satisfied, somewhat dissatisfied, very dissatisfied?

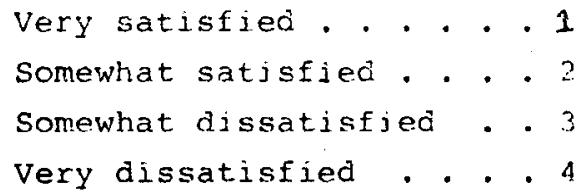

24. Before (CHILD) entered school about how often would you say that you or members of your family read to him--frequently, occasionally, or hardly ever?

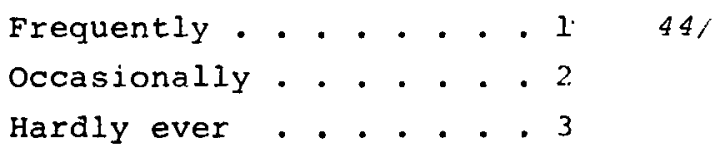

25. Now we would like to know how satisfied you are with various groups and people connected with the schools. Using the categories on this card, please tell me how satisfied are you with the job (CHILD'S) (homeroom) teacher is doing? (RECORD BELOW)

26. How about the principal ..- how satisfied are you with the job the principal of (CHILD'S SCHOOL) is doing? (RECORD BELOW)

27. How about Parent's Associations or the PTA - how satjsfied are you with the job they are doing in (CHILD'S SCHOOL)? (RECORD BELOW)

28. In general, how satisfied are you with the job the Alum Fock Board of Trustees (School Board) is doing? (RECORD BEL,W)

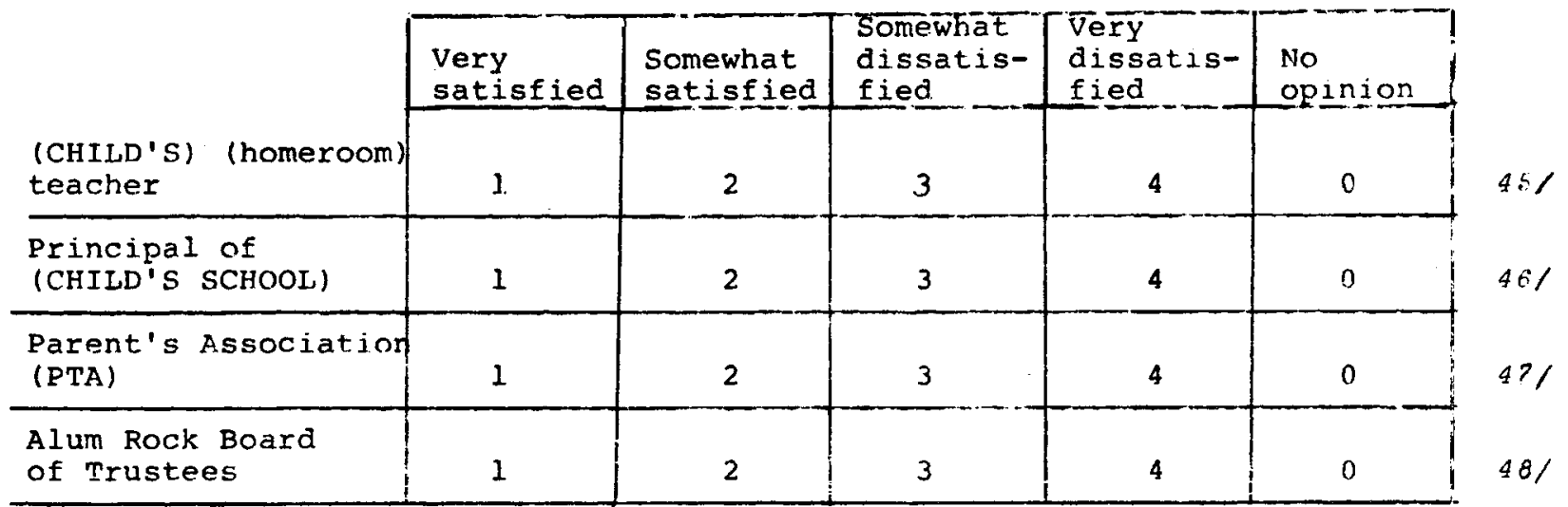


29. I will now read statements often made by people about government, schools, and current issues. Would you tell me how strongly you agree or disagree with each of these statements by selecting one of the answers on this card?

HAND 3

\begin{tabular}{|l|l|l|l|l|}
\hline $\begin{array}{l}\text { Strongly } \\
\text { agree }\end{array}$ & Agree & $\begin{array}{l}\text { Don't } \\
\text { know }\end{array}$ & $\begin{array}{l}\text { Dis- } \\
\text { agree }\end{array}$ & $\begin{array}{l}\text { Strongly } \\
\text { Disagree }\end{array}$ \\
\hline
\end{tabular}

A. Parents should have more to say about what their children learn in school 1 2 3 4 $49 /$

B. The really important decisions in a household should be made by the man

c. I care a lot what my

neighbors think

1

12

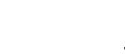

schools should receive financial

$\begin{array}{llllllll} & \text { aid from public tax money } & 1 & 2 & 3 & 4 & 5 & 52 /\end{array}$

care too much about the

poor and not enough about the average man

1

1

2

2

Obedience and respect for authority are the most important things children can learn

1

2

3

4

5

\begin{tabular}{|c|c|c|c|c|c|c|}
\hline F. & $\begin{array}{l}\text { Obedience and respect for } \\
\text { authority are the most } \\
\text { important things children } \\
\text { can learn }\end{array}$ & 1 & 2 & 3 & 4 & 5 \\
\hline G. & $\begin{array}{l}\text { In general teachers and } \\
\text { principals don't want the } \\
\text { advice of parents }\end{array}$ & 1 & 2 & 3 & 4 & 5 \\
\hline H. & $\begin{array}{l}\text { Most parents like the idea } \\
\text { that they should have a } \\
\text { choice about the kinds of } \\
\text { schools their children } \\
\text { attend }\end{array}$ & 1 & 2 & 3 & 4 & 5 \\
\hline I. & $\begin{array}{l}\text { Children will get a better } \\
\text { education if their parents } \\
\text { can select the school that } \\
\text { they go to }\end{array}$ & 1 & 2 & 3 & 4 & 5 \\
\hline J. & $\begin{array}{l}\text { It is the duty of the } \\
\text { government in Washington } \\
\text { to provide a job for every- } \\
\text { body who wants to work }\end{array}$ & 1 & 2 & 3 & 4 & 5 \\
\hline $\mathrm{K}$. & $\begin{array}{l}\text { Busing elementary school } \\
\text { children to schools in other } \\
\text { parts of the city only } \\
\text { harms their education }\end{array}$ & 1 & 2 & 3 & 4 & 5 \\
\hline
\end{tabular}


30. In general, how satisfied are you with the kind of education your child(ren) can get in Alum Rock -- are you very satisfied, somewhat satisfied, somewhat dissatisfied or very dissatisfied?

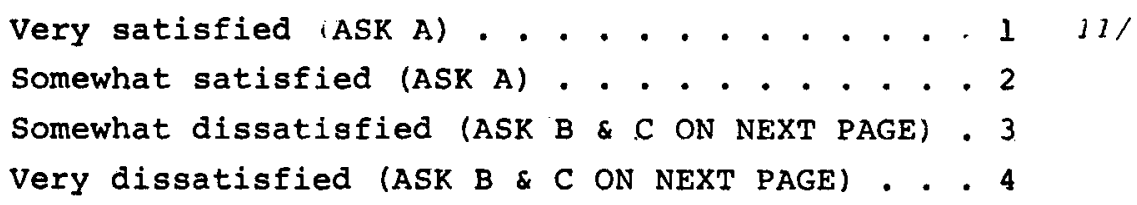

IF VERY OR SOMEWHAT SATISFIED:

A. Even though you are generally satisfied with the kind of education your child(ren) can get in Alum Rock, are there some changes that you think the schools should make which would give your child(ren) an even better education?

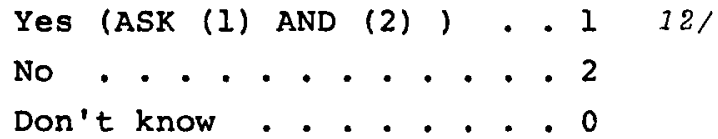

IF YES TO A:

(1) What kinds of changes?

(2) Have you or anyone you know tried to do anything to get the

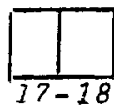
schools to make those kinds of changes?

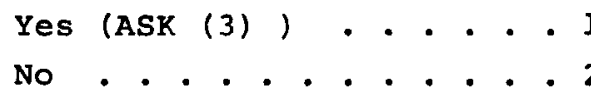

(3) IF YES TO 2: What have you (they) tried to do? 
30. (continued)

\section{IF VERY OR SOMEWHAT DISSATISFIED:}

B. What are some of the things you would like to see changed or things you think would give your child a better education?
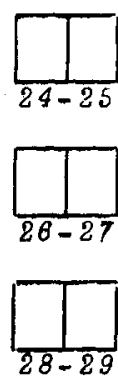

c. Have you or anyone you know tried to do anything about these things?

$$
\begin{aligned}
& \text { Yes (ASK (1) ) . . . . 1 30/ } \\
& \text { No }(A S K(2)), \ldots . .2
\end{aligned}
$$

IF YES TO C:

(1) What have you (they) tried to do?
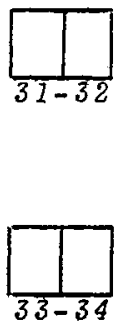

IF NO TO C:

(2) What, if anything, do you think you could do about it?
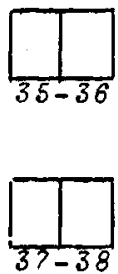
A. Now let's see...your child(ren) (is/are) in CODE in COt, A BELOW THE SCHOOL RESPONDENT'S CHILD(REN) ATTSND(S). (RFFEK TO Q. 5, PAGE, 2.)

B. Here is a list of some of the elementary and middje schools in Alum Rock. (HAND CARD A) Going down that list, please tell me which ones you have ever heard of. CODE IN COI. B ALL RESPONDENT MAS HFARD OF.

Can you tell me the names of any other public elerentary or middle schonis in Alum Rock. CODE IN COL. B P.LL SCHOOLS RESPONDENS NAMES.

C. FOR EACH SCHOOL CIRCLED IN EITHER COL. A OR B. DO yOu know sometring about the quality of that school or not? CODE UNDFR COLUMN

D. Now we'd like to get a little better idea of what you trink of the schro: your child(ren) go(es) to. Here is a picture of a ladder (SHOW CARD D). Suppose we say that the top of the ladder (POINTING) is the very best school you can think of and the botton (POINTING) is the very worst school you can think of. Where on the ladder (MOVING FINGER RAPIDLY UE AND DOWN) would you place (FIRST SCHOOL CODED IN COL. A)? WRITE IN STEF NUMBER IN COL. D. REPEAT FOR EACH SCHOOL CODED IN COL. A.

Now, let's see, you said you knew something about the guality of (FIRST SCHOOL CODED UNDER "SOMETHING" COLUMN). Based on what you know about that school, where on the ladder would you place it? WRITF IN STEP NUMBER IN COL.'

D. REPEAT FOR EACH SCHOOL KNOW "SOMETHING" ABOUT.

A.

\begin{tabular}{|c|c|c|}
\hline & $\begin{array}{l}\text { School } \\
\text { child (ren) } \\
\text { attend }\end{array}$ & $\begin{array}{l}\text { Others } \\
\text { have } \\
\text { heard of }\end{array}$ \\
\hline CASSELL & 1 & 2 \\
\hline GOSS & $I$ & 40 \\
\hline MCCOLLAM & $I$ & 411 \\
\hline MEYER & $I$ & 421 \\
\hline MILLER & $I$ & 43 \\
\hline$\overline{\text { PALA }}$ & I & 441 \\
\hline
\end{tabular}

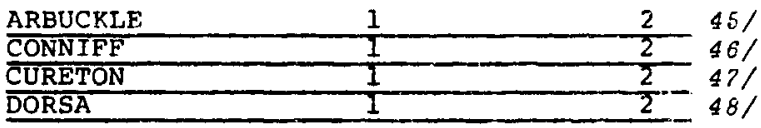

\begin{tabular}{lll} 
FISCHER & 1 & 2 \\
\hline GEORGE & 1 & $49 /$ \\
\hline HUBBARD & 1 & 2 \\
\hline LINDA VISTA & 1 & $50 /$ \\
\hline
\end{tabular}

\begin{tabular}{llr} 
LYNDALE & 1 & 2 \\
\hline MATHSON & 1 & $53 /$ \\
\hline MAYFAIR & 1 & 2 \\
\hline PAINTER & 1 & 2 \\
\hline
\end{tabular}

\begin{tabular}{|c|c|c|}
\hline ROGERS & 1 & 2 \\
\hline RYAN & $\frac{1}{7}$ & 2 \\
\hline $\begin{array}{l}\text { SAN ANTONIO } \\
\text { SHEPPARD }\end{array}$ & 1 & $\frac{2}{2}$ \\
\hline
\end{tabular}

SHIELDS SIONAKER

$$
\text { Begiricaple lere }
$$

Knowledge

\begin{tabular}{ll} 
Sorie- & Step \\
thing Nothing & Number \\
\hline
\end{tabular}
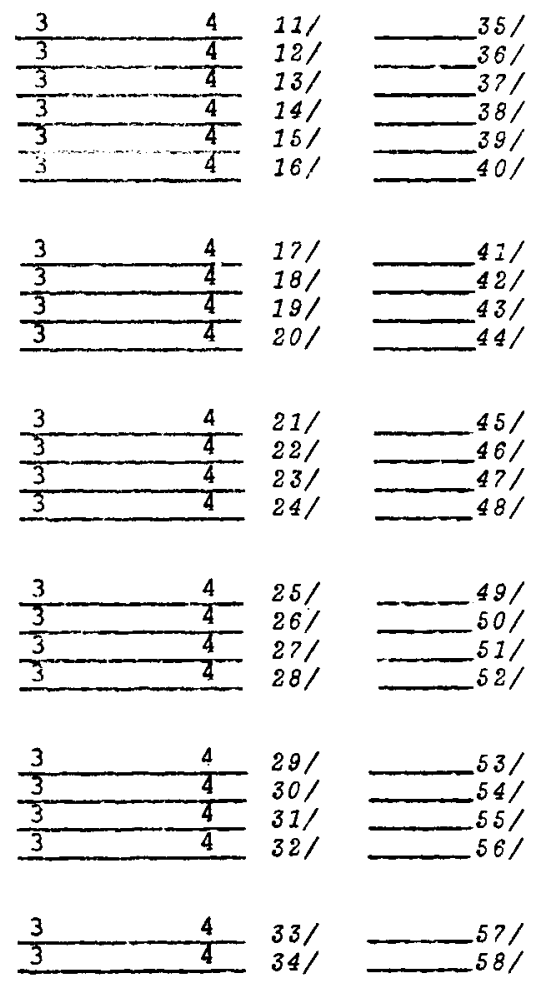
Begin Card 17 Here

Now I'd like to talk more about the school(s) your child(ren) in grades kindergarten through eighth grade go(es) to...

Let's see, your child(ren) attend(s) . . WRITE IN NAMFS OF SCHOOLS

(GRADES K-8)

NAMES OF SCHOOLS CHILD(REN) GO(ES) TO:

ASK FOR EACH SCHOOL:

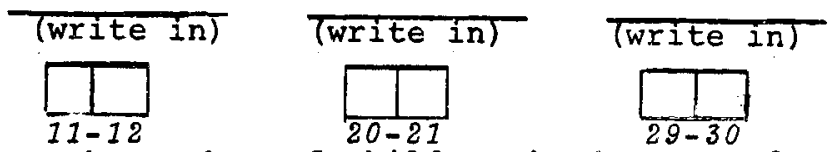

32. Do you personally think that the number of children in (SCHOOL) from each of the racial or cultural groups is about right, or do you think there should be fewer of some, or more of some, or what? (CODE ALL THAT APPLY.)

\begin{tabular}{|c|c|c|c|c|}
\hline \multirow{7}{*}{$\begin{array}{l}\text { Would } \\
\text { like: }\end{array}$} & a. About right & $113 /$ & $122 /$ & 1311 \\
\hline & b. Fewer chicano & $214 /$ & 2231 & $232 /$ \\
\hline & c. Fewer Anglo (white) & 3751 & 3241 & 333 \\
\hline & d. Fewer black & $416 /$ & 4251 & 4341 \\
\hline & e. More chicano & $517 /$ & $526 /$ & $535 /$ \\
\hline & f. More Anglo (white) & $618 /$ & 6271 & 6361 \\
\hline & g. More black & $719 /$ & 7281 & 7371 \\
\hline
\end{tabular}

33. As you know, a certain amount of money goes to the public elementary schools here in Alum Rock. Do you think the schools are getting too much money, not enough money, or about the right amount to do their job?

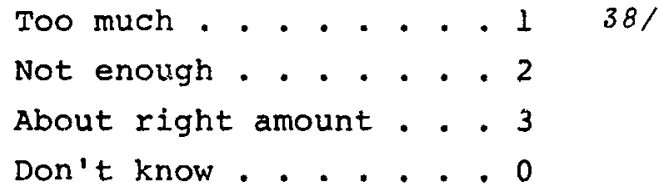

34. Are the schools making very good, good, fair, or poor use of the money they get, as far as you can tell?

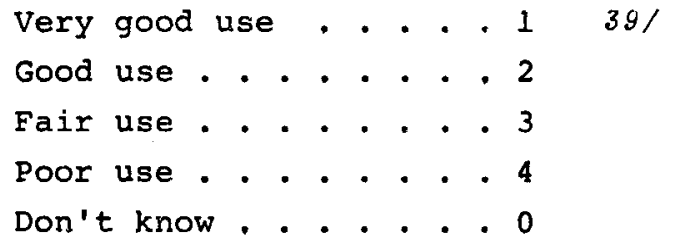


35. I will now read some more statements and you tell me how strorgly you agree or disagree with each of these statements by selecting one of the answers on this card.

HAND
CARD $C$

\begin{tabular}{|l|l|l|l|l|}
\hline $\begin{array}{l}\text { Strongly } \\
\text { Agree }\end{array}$ & Agree & $\begin{array}{l}\text { Don't } \\
\text { Know }\end{array}$ & $\begin{array}{l}\text { Dis- } \\
\text { agree }\end{array}$ & $\begin{array}{l}\text { Strongly } \\
\text { Disagree }\end{array}$ \\
\hline
\end{tabular}

A. Getting ahead depends on who you know more than how

Elected officials in
general can be trusted

Blected officials in
general can be trusted

1

c. In some cases it's best

for children to attend

elementary schools outside

their own neighborhood

1

23

4

5

421

D. Giving parents a choice about

the schools their children

attend will make teachers

more responsive to their

complaints and suggestions

1

1

2

3

4

5

431

E. Political corruption is a necessary evil in government

1

2

3

441

F. In the next few years,

things are not really going

to improve for the average

man

1

3

4

5

$45 /$

G. Teachers in the schools of

Alum Rock should live in

Alum Rock

1

2

3

4

461

H. People like me don't have

anything to say about what the government does

1

2

3

4

5

471

I. Over the past few years, blacks have got more than they deserve.

1

2

3

4

5

$48 /$

J. Public officials don't really care what people like me think

1

2

3




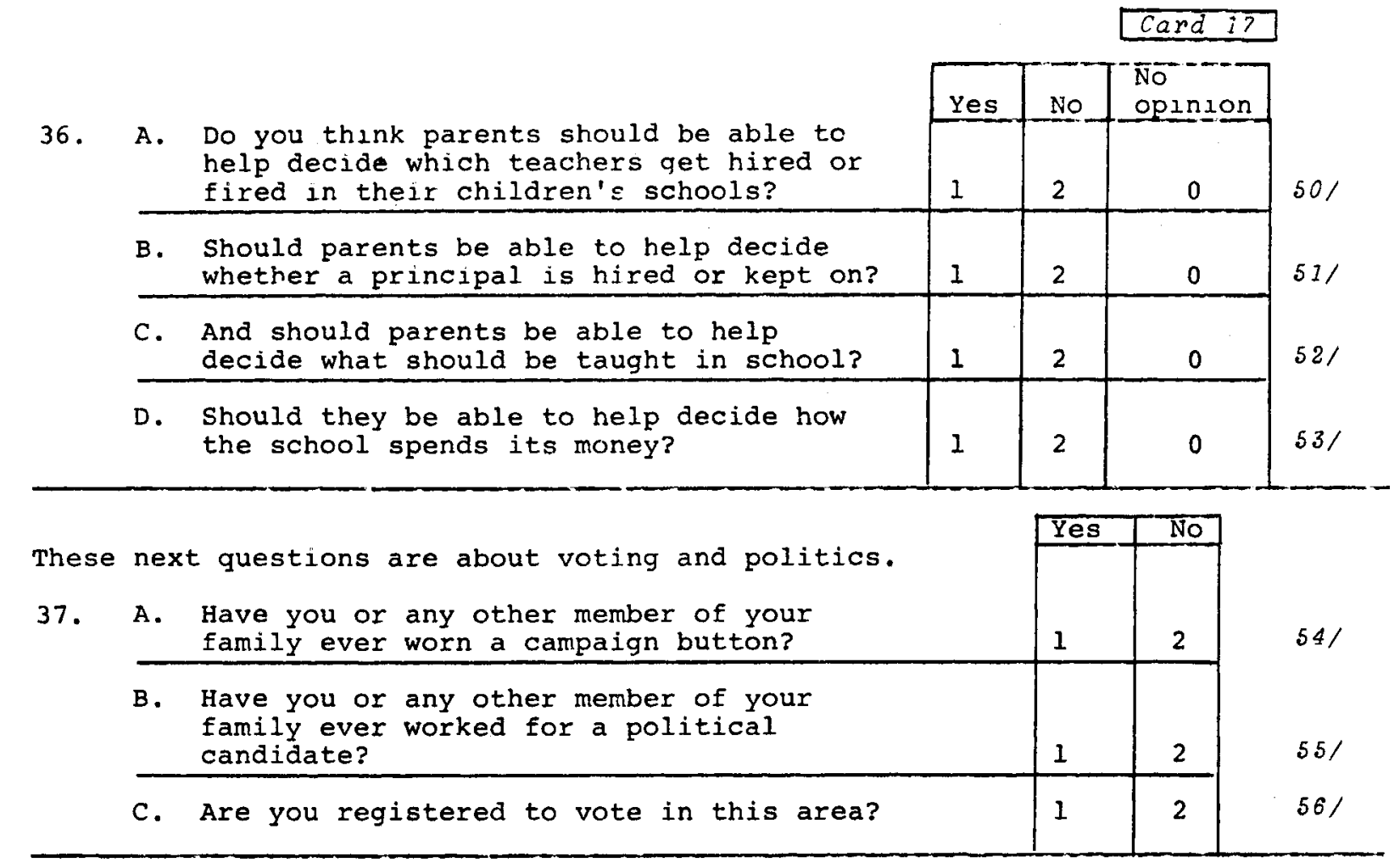

And now on a somewhat different subject.

38. Have you heard about the educational voucher program that started in some of the schools here in Alum Rock this year?

$$
\begin{aligned}
& \text { Yes } \cdot \cdot \cdot \cdot \cdot \cdot \cdot \cdot \cdot \cdot 1 \\
& \text { No (SKIP TO Q. } 53 \text { ) } \cdot 2
\end{aligned}
$$

39. How good a job do you feel the school system has done in explaining the voucher system and how it works--do you think they have done a very good job, a good job, a fair job, or a poor job?
A very good job . . . 1
A good job . . . . 2
A fair job . . . . 3
A poor job . . . . 4
No opinion . . . . 0 
40. Now we would like to find out where and how much information you received about the voucher system and the different programs being offered by the schools.

HAND

A. First, in which of these ways did you get any information about the voucher system and the different programs being offered by the schools? (RECORD UNDER COLUMN A).

B. Considering all the different ways you learned about the voucher system, which was the most helpful to you? (CODE IN COL. B).

C. Which was the least helpful to you? (CODE IN COL. C)

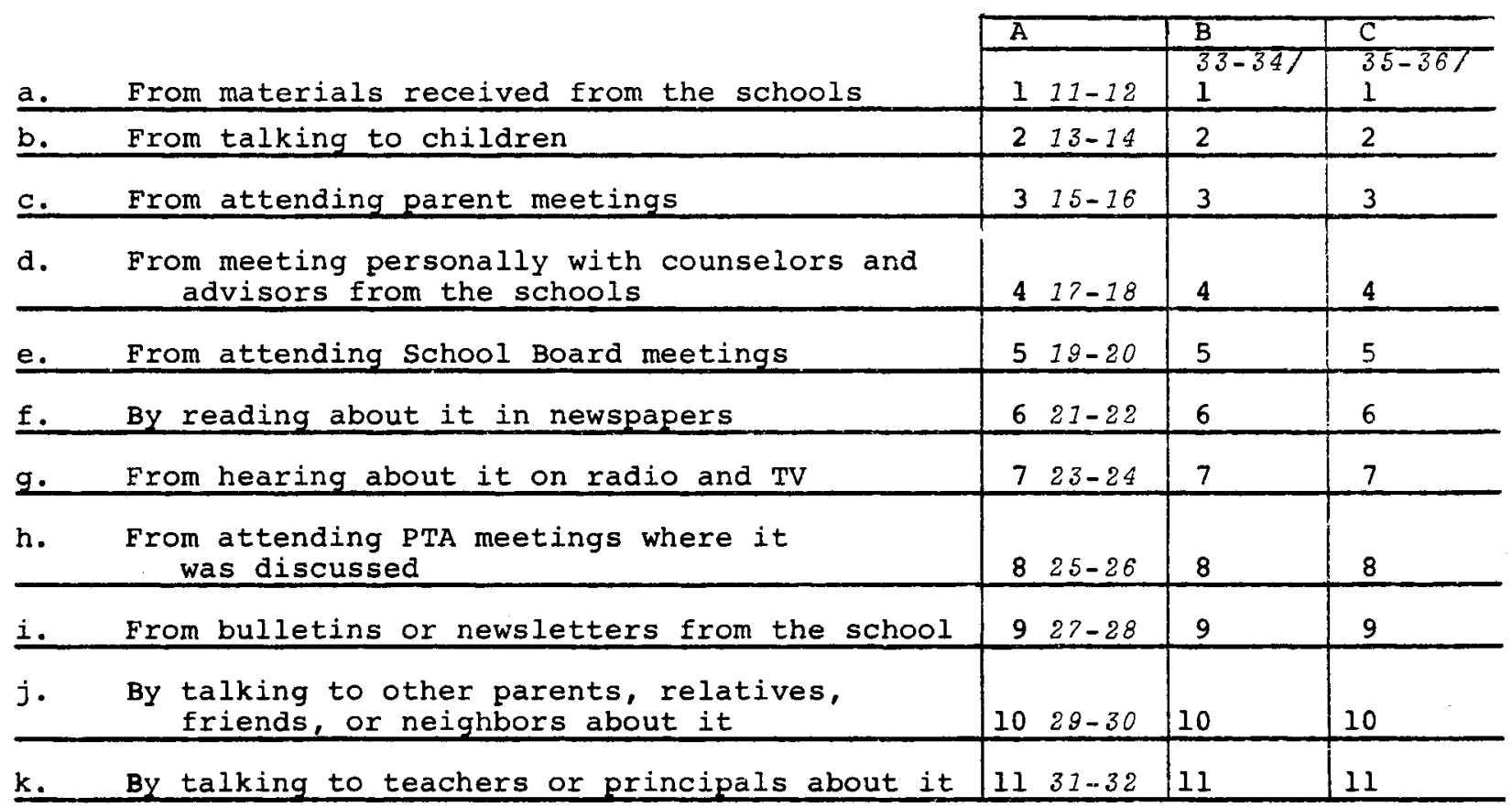


41. A. The school district gave parents enrollment forms to fill out for their children. Did you personally fill out these forms?

$$
\begin{aligned}
& \text { Yes. (CODE "I" IN COL. A BELOW) } \\
& \text { No . Ask: Who did? (CODE IN COL. A) }
\end{aligned}
$$

B. Did (YOU/PERSON CODED IN COL. A) talk with anyone else about which program and which school to choose for your children?

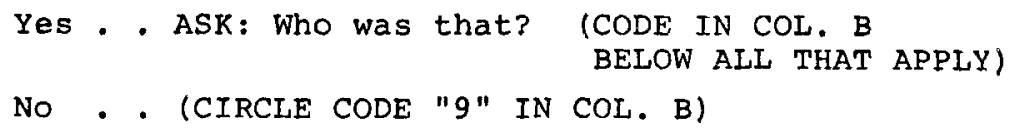

\begin{tabular}{|c|c|c|c|c|c|c|c|c|}
\hline \multirow[b]{2}{*}{ Respondent } & $\overline{\mathrm{A}}$ & $\bar{B}$ & \multirow{2}{*}{\multicolumn{2}{|c|}{$38 /$ (ASK }} & \multirow[b]{2}{*}{$\mathrm{C}$} & \multirow[b]{2}{*}{$\& D$} & \multirow{2}{*}{\multicolumn{2}{|c|}{ BELOW) }} \\
\hline & $137 /$ & 1 & & & & & & \\
\hline Respondent's (husband/wife) & 2 & 2 & $39 /$ & & & & & \\
\hline Other adult in family & 3 & 3 & 401 & & & & & \\
\hline Child/children themselves & 4 & 4 & 411 & & & & & \\
\hline Other children outside the family & 5 & 5 & $\$ 21$ & & & & & \\
\hline Teachers & 6 & 6 & 431 & (ASK & $\mathbf{E}$ & ON & NEXT & PAGE) \\
\hline $\begin{array}{l}\text { Parent Counselors or advisors } \\
\text { at school }\end{array}$ & 7 & 7 & $44 !$ & (ASK & $\mathbf{F}$ & ON & NEXT $F$ & PAGE; \\
\hline Other parents, friends, neighbors & 8 & 8 & $45^{\prime}$ & (ASK & G & ON & NEXT F & PAGF:j \\
\hline To one helped me & & 9 & $46 /$ & & & & & \\
\hline Don't remember & 0 & 0 & 471 & & & & & \\
\hline
\end{tabular}

IF RESPONDENT MADE CHOICE OR HELPED TO MAKE CHOICE, ASK C AND D BELOW:

C. When it came time to make a choice, did you find you had enough information about the different programs being uffered in the school(s) you selected for your child(ren) or would you have liked to have had more information about the programs offered there?

$$
\begin{aligned}
& \text { Had enough information . . } 148 \text { / } \\
& \text { Wanted more information . . } 2 \\
& \text { Can't say . . . . . . . . } 0
\end{aligned}
$$

D. What about the other schools in the voucher system, did you feel you had enough information about the different programs they were offering or would you have liked to have had more information about the programs offered at the other schools?

$$
\begin{aligned}
& \text { Had enough information . . } 149 / \\
& \text { wanted more information . . } 2 \\
& \text { Can't say . . . . . . . . } 0
\end{aligned}
$$


IF TEACHER MADE CHOICE OR HELPED:

E. How good a job do you feel

teachers have done in explaining the voucher system and how it works--do you think they have done a very good job, a good job, a fair job, or a poor job?

IF PARENT COUNSELLORS/ADVISORS MADE CHOICE OR HELPED :

F. How good a job do you feel parent counselors have done in explaining the voucher system and how it works--do you think they have done a very good job, a good job, a fair job, or a poor job?

IF FRIENDS, NEIGHBORS, OTHER PARENTS MADE CHOICE OR HELPED:

G. How good a job do you feel the friends, neighbors or parents you talked with have done in explaininal the voucher system and how it works--do you think they have done a very good job, a good job, a fair job, or a poor job? 
42. Here is a list of groups and people that the voucher system will affect. HAND CARD

ASK ABOUT EACH GROUP IISTED BELOW: Do you think that (GROUP) will be helped or hurt by the voucher system? (RECORD RESPONSE UNDER COL. $A$. THEN ASK: Do you think they will be (helped/hurt) a lot or a little? (CODE UNDER COL. B.)

\begin{tabular}{|l|l|l|l|l|l|}
\hline \multicolumn{2}{|c|}{ Col. A } & \multicolumn{3}{c|}{ Col. B } \\
\hline Helped & Hurt & Neither & $\begin{array}{l}\text { Don't } \\
\text { know }\end{array}$ & $\begin{array}{l}\text { A } \\
\text { Lot }\end{array}$ & $\begin{array}{l}\text { A Little } \\
\text { Lith }\end{array}$ \\
\hline
\end{tabular}

A. Children from lower income families

B. Children from midale and upper income families

1

\begin{tabular}{|c|c|c|c|c|c|c|c|c|c|}
\hline & Eamilies & 1 & 2 & 3 & 4 & $54 /$ & 1 & 2 & 621 \\
\hline c. & Black children & 1 & 2 & 3 & 4 & $55 /$ & 1 & 2 & 631 \\
\hline D. & White/Anglo children & 1 & 2 & 3 & 4 & $56 /$ & 1 & 2 & $64 /$ \\
\hline E. & $\begin{array}{l}\text { Chicano or Mexican- } \\
\text { American children }\end{array}$ & 1 & 2 & 3 & 4 & $57 /$ & 1 & 2 & $65 /$ \\
\hline F. & Teachers & 1 & 2 & 3 & 4 & $58 /$ & 1 & 2 & $66 /$ \\
\hline G. & School administrators & 1 & 2 & 3 & 4 & 591 & 1 & 2 & $6 ?$ \\
\hline H. & Parents & 1 & 2 & 3 & 4 & $60 /$ & 1 & 2 & $\epsilon 8 ;$ \\
\hline
\end{tabular}

As you may know, under the voucher system, each school offers several different ways of teaching children. These are called programs. The idea is for parents to be able to select from different types of educational programs and classroom approaches the one they think would be best for their children.

43. Taking everything together, do you think giving parents a choice between different types of programs is a very good idea, a good idea, a fair idea, or a poor idea?

$$
\begin{aligned}
& \text { Very good idea . . . I. 69/ } \\
& \text { Good idea . . . . } 2 \\
& \text { Fair idea . . . . } 3 \\
& \text { Poor idea . . . . } 4 \\
& \text { No opinion . . . . } 0
\end{aligned}
$$


44. This school year, would you say that there are too many different programs available, too few, or just about the right number?

$$
\begin{aligned}
& \text { Too many . . . . . . . . } 1 \\
& \text { Too few . . . . . . . } 2 \\
& \text { About the right number . } 3 \\
& \text { No opinion . . . . . . } 0
\end{aligned}
$$

45. At the time you had to decide which school your child(ren) would attend, was there some kind of special program you wanted the schools to offer that they didn't offer?

$$
\begin{aligned}
& \text { Yes }(\operatorname{ASK} \text { A) } \\
& \text { No . . . . . . . . . . . . } 2
\end{aligned}
$$

A. IF YES: What was it you wanted that they didn't offer?
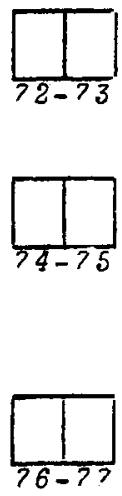

46. How satisfied are you with the kinds of programs offered this school year--very satisfied, somewhat satisfied, somewhat dissatisfied, or very dissatisfied?

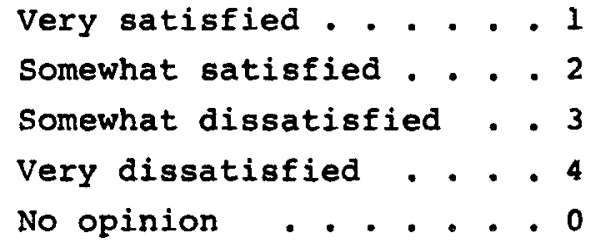


Begin Card 79 Here

47. Overall, do you think the chances of your child(ren) getting the kind of education you want for (him/her/them) are better under the voucher system, about the same, or not as good as they were last year?

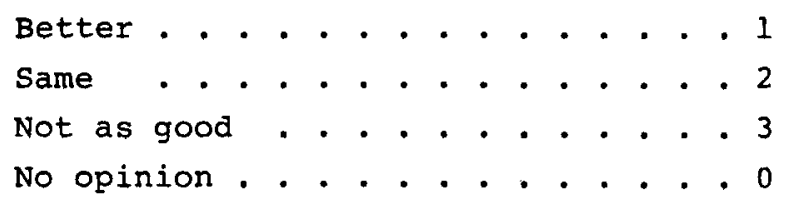

48. As far as you know, under the voucher system, if a parent wants to serd his child to a school that is not in his own neighborhood, does the parent have to provide transportation himself, does the child use city buses, or is transportation provided free of charge?

$$
\begin{aligned}
& \text { Parent must provide transportation - } 1 \\
& \text { Child uses city buses - . - . . } 2 \\
& \text { Transportation free of charge . . . } 3 \\
& \text { Don't know . . . . . . . . . . } 0
\end{aligned}
$$

The next few questions are about the school (CHILD ABOUT WHOM Q. 7-24 WERE ASKED) goes to. (INTERVIEWER: REFER BACK TO PAGE 4 FOR IINE NUMBER AND NAME OF CHILD.)

49. Why did you select that school for (CHILD)?
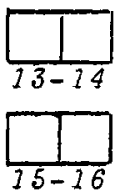

50. Is (CHILD) attending the "school" nearest your home, or is (he/she) going to a different school?

School nearest home . . . . . . 1
Different school . . . . . . . 2

51. Some schools have more than one program. Do you happen to know which program (CHILD) is enrolled in?

$$
\begin{aligned}
& \text { Yes (ASK A AND B) . . . . . . . } 1 \\
& \text { No } . . . \\
& \hline
\end{aligned}
$$

IF YES:

A. What is that program called:

B. Is this your first choice for (him/her)?

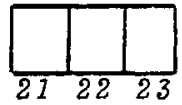

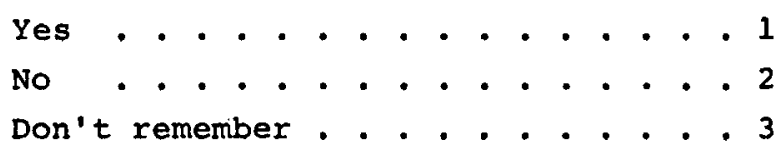




\section{Card 9}

52. Is there anything about the particular program (CHILD) is in that you think might be especially good or especially bad for (him/her)?

$$
\begin{aligned}
& \text { Yes, especially good (ASK A) . . } 1 \\
& \text { Yes, especially bad (ASK B) . . } 2 \\
& \text { Yes, both (ASK A AND B) . . . . } 3 \\
& \text { No, neither . . . . . . . . . } 4
\end{aligned}
$$

A. IF ESPECIALLY GOOD OR BOTH: What is it about the program that you think will be especially gooz for (CHILD)?

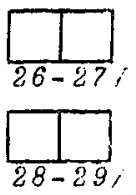

B. IF ESPECIALIY BAD OR BOTH: What is it about the program that you think will be especially bad for (CHILD)?

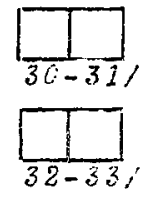

53. In your experience does (CHILD'S) (homeroom) teacher pay a lot, somn or hardly any attention to suggestions or complainss from parents?

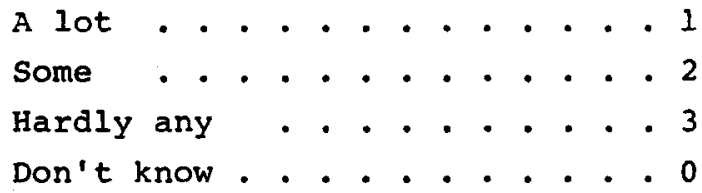

54. How about the principal--does the principal pay a lot of attention, some, or hardly any attention to suggestions or complaints from parents?
A lot . . . . . . . . . . 1
Some
Hardly any . . . . . . . . . 3
Don't know......... 0 
55. Now I have it iew statements about the voucher systera and I would l.1ke yol to tell me hon strongly you agree or disagree with each of them by selecting one of tile answers on this card.

\begin{tabular}{|c|c|c|c|c|c|}
\hline $\begin{array}{l}\text { HAND } \\
\text { CARD }\end{array}$ & $\begin{array}{l}\text { Strongly } \\
\text { Agree }\end{array}$ & Agree & $\begin{array}{l}\text { Don } t \\
\text { Know }\end{array}$ & Disagree & $\begin{array}{l}\text { Strongly } \\
\text { Disagree }\end{array}$ \\
\hline
\end{tabular}

A. The voucher system will

result in better public

schools in fillm Rock

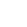

Under the voucher system

a paxent can change the schcol his child attends at regular times curing the school year

C. Some families will leave
Alum Rock rather than have
their children go to
voucher schools

D. Parents should be able to use vouchers in parochial and private as well as putlic schools

1

12

1

1

2

3

4

5 $38 /$

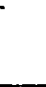

E. Under the voucher system

the more schools a parent has to choose from, the rucre control parents will have cver the school syster 1 2 3

4 $40 /$

F. The voucher system will do more for the education of blacks and Chicanos than

it will for the education of whites 1

$2 \quad 3$

4 $i \mathfrak{i}$

G. Under the voucher system some schools would have too many students and other schools would have empty classaccms

2 3

4 $4 \%$

H. For most parents how close a school is to home is the most important reason for choosing a school for his children to attend 1

2

2 3

4 5 436

I. The voucher system will give parents more control over the schocls of Alum Rock 1 2 3 4 5 
Now try to think back to last year before there was any discussion of the voucher system.

56. Did you have any children in school in Alum Rock last year?

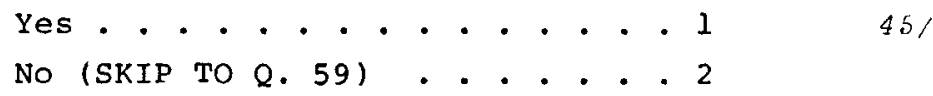

57. How many times did you or other members of your family do any of the following things during the last school year... (READ LIST BELCW) WRITE IN NUMBER OF TIMES OR CIRCLE "O" FOR NONE

Number

times. None

A. Have talks with the teachers or other people at the school about your children

- $0 \quad 46-471$

B. Attend any parent or neighborhood meetings at which the schools were discussed

- $048-49$

C. Attend any special events at elementary schools, such as plays

or ballgames or special assemblies, etc. . . 0 50-51/

58. Last year, did you or any other members of your fanily belong to any cormittees or groups at your elementary school, such as the PTA, the Chicano Parents of Alum Rock, or other parent groups?

$\begin{array}{lllllllllll}\text { Yes } & (\text { ASK } & \text { A }) & \cdot & \cdot & \cdot & \cdot & \cdot & \cdot & \cdot \\ \text { No } & \cdot & \cdot & \cdot & \cdot & \cdot & \cdot & \cdot & \cdot & \cdot & \cdot\end{array}$

A. IF YES: Which committee or group did you or anyone in your family belong to:

The Chicano Parents of Alum Rock 1
PTA - . - . . - . . . . . 2
Other(s) (SPECIFY)


59. Last year, did you or anyone else in your family attend any special public or neighborhood meetings about local issues not related to the schools?

$$
\begin{aligned}
& \text { Yes (ASK A) . . . . . . . } 1 \\
& \text { No } \cdot . \cdot . \cdot . \cdot . \cdot .2
\end{aligned}
$$

A. IF YES: How many such meetings did you or anyone of your family attend? RECORD BELOW

(total number of public or neighborhood meetings)

60. Does your family have a dictionary here at home?

$$
\begin{aligned}
& \text { Yes . . . . . . . . . } 1 \\
& \text { No } . . . . . . . . .2
\end{aligned}
$$$$
571
$$

61. Does your family have an encyclopedia here at home?

$$
\begin{array}{llllllllll}
\text { Yes } & \cdot & \cdot & \cdot & \cdot & \cdot & \cdot & \cdot & 1 \\
\text { No } & \cdot & \cdot & \cdot & \cdot & \cdot & \cdot & \cdot & \cdot
\end{array}
$$$$
581
$$

62. Do you receive any magazines regularly here at home?

$$
\begin{array}{lllllllll}
\text { Yes } & \cdot & \cdot & \cdot & \cdot & \cdot & \cdot & \cdot \\
\text { No } & \cdot & \cdot & \cdot & \cdot & \cdot & \cdot &
\end{array}
$$

63. About how often do you get a newspaper here at home--every day, a few times a week, once a week, or less often than that?

$$
\begin{aligned}
& \text { Every day . . . . . . } 1 \\
& \text { Few times a week . . . } 2 \\
& \text { Once a week . . . . . } 3 \\
& \text { Less often . . . . . . } 4 \\
& \text { Not at all..... . } 5
\end{aligned}
$$$$
60
$$

And now a few questions about your background.

64. A. How long have you lived in Santa clara county? CODE IN COLUMN A.

$$
\begin{aligned}
& \text { Less than } 1 \text { year..... } \frac{\sqrt{A}}{i^{61}}-\frac{B}{1^{62}} \\
& \text { One to less than } 2 \text { years. . } 2 \\
& \text { Two to less than } 3 \text { years. . } 3 \text { 3 } \\
& \text { Three to less than } 5 \text { years . } 4 \quad 4 \\
& \text { Five to less than } 10 \text { years. } 5 \\
& \text { Ten years or longer . . . . } 6 \quad 6
\end{aligned}
$$

B. How long have you lived at this address: CODE IN COL. B ABOVE. 
65. Which of these phrases (HAND CARD G) best describes how likely it is that you and your family might move away from Alum Rock within the next two years?

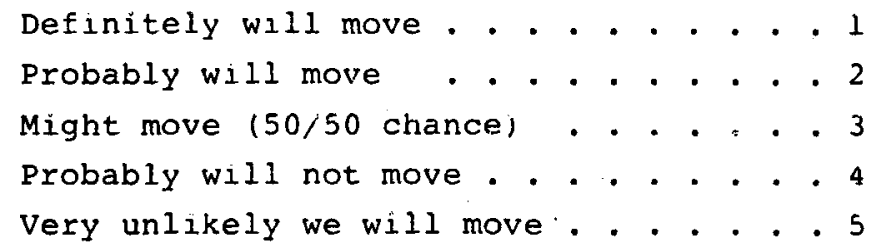

66. Altogether, including yourself, how many adults 18 and over live here in this household most of the year? (No. adults in household)

67. A. Do you have any children who are not yet in school, that is, tco young to be in school? IF NO, CIRCLE "O". IF YES: How many?

Number not yet in school: None ................ 0

B. Do you have any children who are out of high school now--just count those who live here and who are under 18? IF No, CIRCLE " 0 ". IF YES: HOW many?

Number out of school:

None .................. 0

68. Are you working full time now, working part time, (keeping house), (retired), or can't you find work, or what?

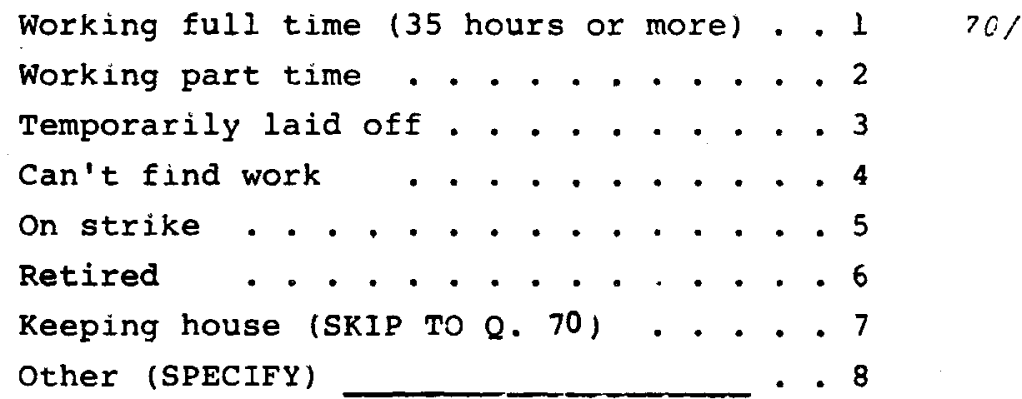

65. A. What kind of work (do/did) you normally do? OCCUPATION

B. In what industry is this?

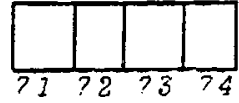

INDUSTRY 
70. What is your present age: WRITE IN: $11-12 /$ IF RESPONDENT REFUSES, PLEASE WRITE IN ESTIMATE ABOVE AND CHECK BOX

71. What was the highest grade or class you completed in school?

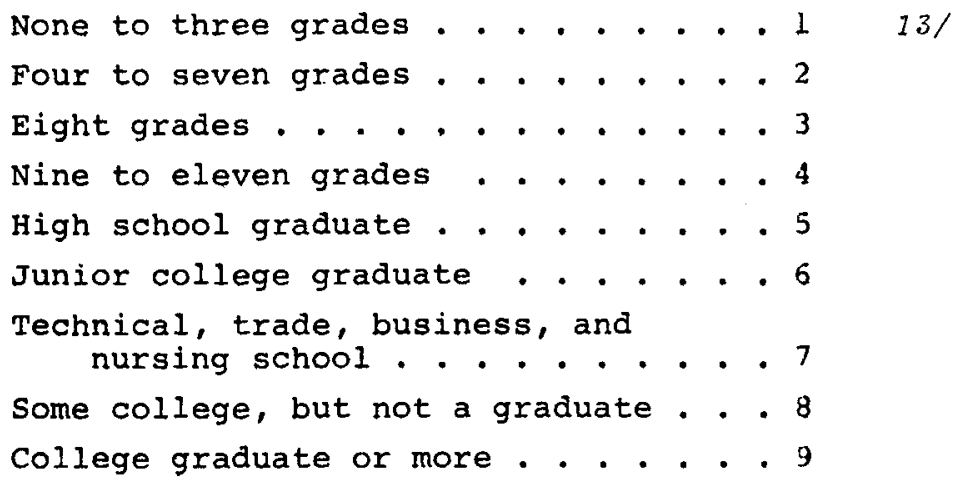

72. Are you married, single, divorced, separated, or widowed?

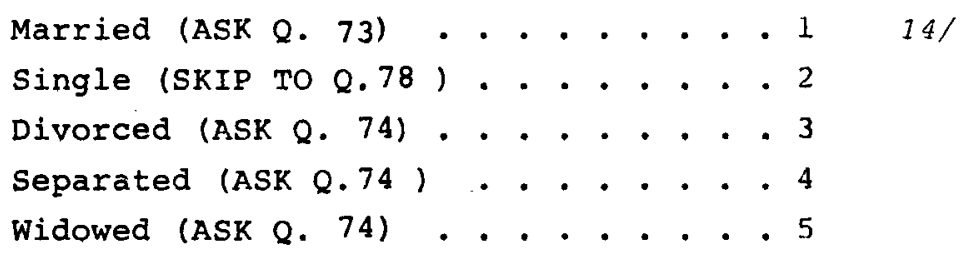

73. Is your (husband) (wife) working full time now, working part time, (retired), or can't (he/she) find work, or what?

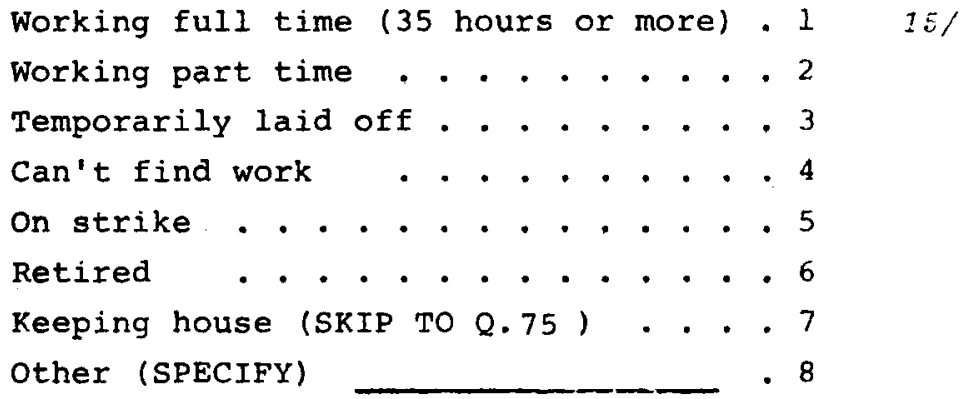




\section{curd $\underline{i}$}

74. A. What kind of work (does/did) your (nusband) iwlie; normally do? OCCUPATION

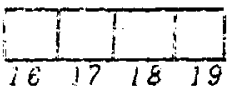

B. In what industry (15/was) this?

INDUSTRY

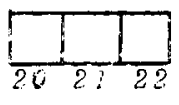

75. What is your (husband's) (wife's) age? WRITE IN:

$23-24$

IF RESPONDENT REFUSES, PLEASE WRITE IN ESTIMATE ABOVE AND CHECK BOX

76. What was the highest grade or class your (husband) (wife) completed in school?

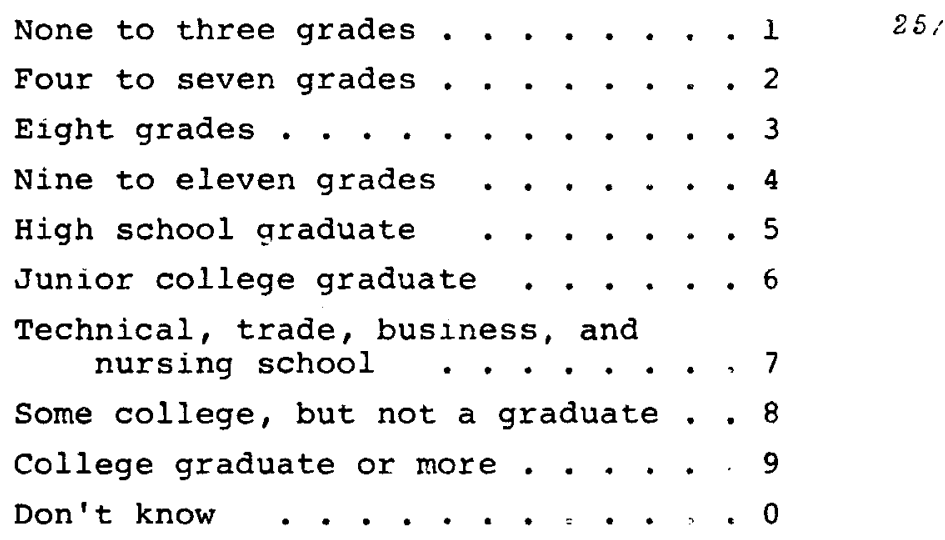

IF INTERVIEWING A WOMAN WHO IS CURRENTLY MARRIED, WIDOWED, DIVORCED OR SEPARATED ASK Q.77 ABOUT HER HUSBAND'S FATHER.

IF INTERVIEWING MAN, ASK ABOUT HIS FATHER.

77. What kird of work did (your) (husband's) father do most of his life?

OCCUPATION

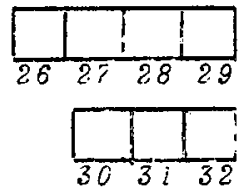

INDUSTRY 
SSK EVERYONE

Card 20

18. Which of the words on the card best describes your race or ethnic background?

\begin{tabular}{l|}
\hline HAND \\
CARD H \\
\hline
\end{tabular}

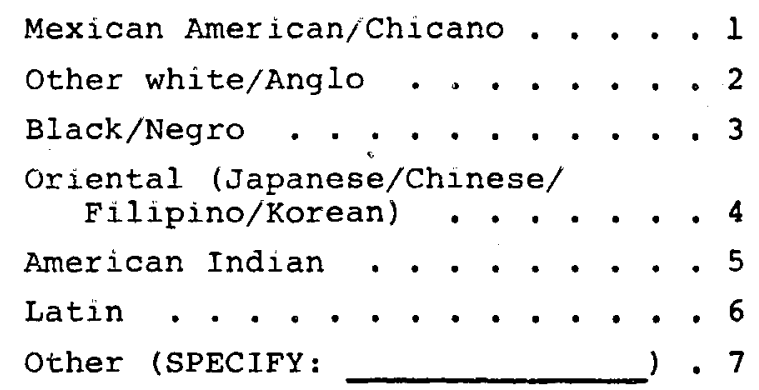

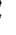


Thank you very much for your help. Please remember that all of the information you have given me is strictly confidential.

PLEASE FILL OUT THE ITEMS BELOW IMMEDIATELY AFTER COMPLETING INTERVIEW
A. Respondent's Male... . $139 /$
sex:
Female . . 2
c. Was this interview conducted in Spanish?
B. Respondent's
race:
White . . $140 /$
Black . . . 2
Yes.... $141 /$
No $\cdot . \cdot .2$
Mexican American . . 3
Other . . . 4

D. How cooperative was respondent?

Very cooperative . . . 1111

Fairly cooperative . . 2

Not cooperative . . . 3

E. How interested was respondent?

Very interested . . . $112 /$

Fairly interested . . . 2

Not interested . . . 3

F. What is color of form used?

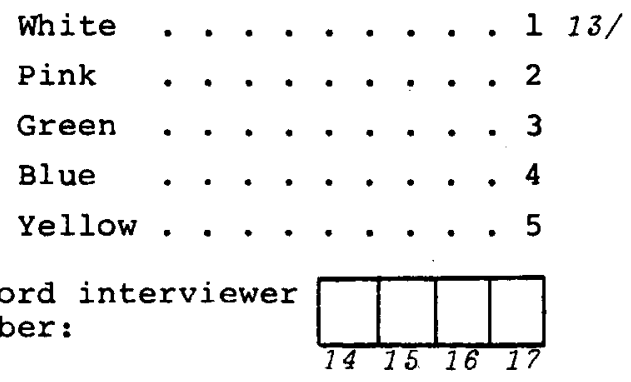

your signature:

Sut: :

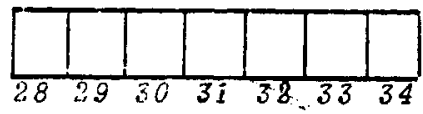

SURS

PAGE \#:

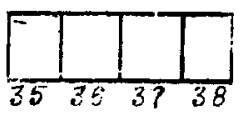

SUPS

LINE \# :

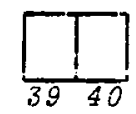

G. Time interview ended:

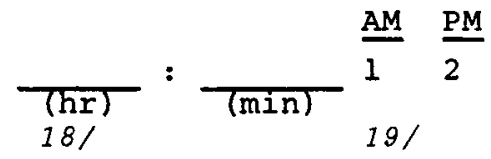

H. Total length of interview:

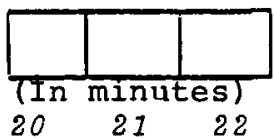

I. Date of interview:

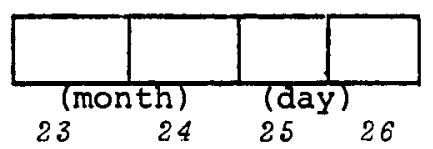

J. Quota type met: (CIRCLE ONE)

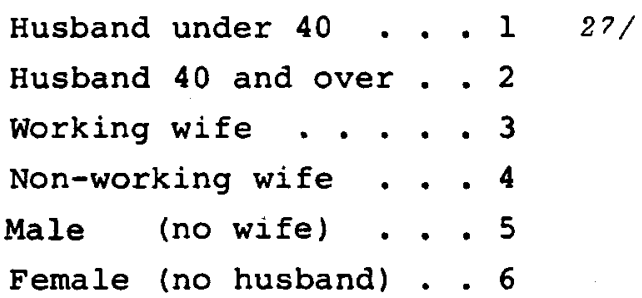

Census Tract \#:

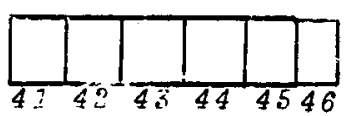

Census Block \#:

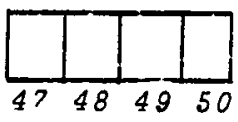




\title{
Appendix VI-B \\ PARENT/COMMUNITY SURVEY
}

\author{
by Robert T. Riley
}

\section{INTRODUCTION}

On November 4, 1972, the interviewers of Field Research Corporation (FRC) entered the field to collect data on 1460 respondents concerning their educational, political and voucher-related attitudes and activities. The Alum Rock survey actually contains five separate survey instruments, and the Alum Rock sample contains six separate subsamples. Parents and nonparents are differentiated from one another as well as respondents who live in the voucher demonstration area and those who do not live in the voucher demonstration area. Hereafter we refer to these areas as the voucher and nonvoucher areas. In addition, there is a separate subsample of changers, parents who changed the school that any one of their children in the voucher area attended and a separate probability sample of parents in the nonvoucher area.

The parent and nonparent samples were drawn using different techniques: the nonparent sample in both the voucher and nonvoucher areas and one of the parent samples in the nonvoucher area employed a block quota sampling method, while the parent sample in the voucher area, the changer sample, and the special subsample of parents in the nonvoucher area employed a probability method. Table V1-B.1 presents a breakdown of the six samples in terms of the number of respondents by the method in which they were drawn.

For five of these six subsamples the interviewers administered a modification of the basic survey form. The voucher parent sample and the changer sample received the same survey form. Additionally, there was a Spanish language version, as well as an English language version, of each of these forms; thus, in total, 10 separate instruments. In Table VI-B.1 we also see the number of respondents by subsample

Table VI-B.1

SAMPLE TYPE BY LANGUAGE OF INTERVIEW

\begin{tabular}{l|r|r|r}
\hline & \multicolumn{3}{|c}{ Language } \\
\cline { 2 - 4 } \multicolumn{1}{c|}{ Sample Type } & English & Span1sh & Total \\
\hline Probab1lity samples & & & \\
Voucher parents & 508 & 92 & 600 \\
Changers & 53 & 3 & 56 \\
Nonvoucher parents & 148 & 36 & 184 \\
& & & \\
Block quota samples & & & \\
Nonvoucher parents & 236 & 22 & 258 \\
Nonvoucher nonparents & 215 & 27 & 242 \\
Voucher nonparents & 98 & 22 & 120 \\
& & & \\
Total, al1 samples & 1258 & 202 & 1460 \\
\hline
\end{tabular}


that received the Spanish language version of this form. Overall, about one-third of all Mexican-American respondents received the Spanish language form.

Forty interviewers administered the questionnaires throughout the Alum Rock area. Approximately one-fourth of these interviewers were bilingual in that they were capable of administering the form in either Spanish or English. All but two of the interviewers were female; there were two young male interviewers. Moreover, there were two black interviewers to interview blacks, who composed a small proportion of the total interviews.

\section{COMPLETED INTERVIEWS}

Within the first week of the survey, that is by November 11 (see Table VI-B.2), the interviewers completed a total of 564 interviews -333 from the parent probability sample and 231 from the block quota sample. At the end of the second week, 485 of the 600 voucher parent interviews and 410 of the 620 block quota interviews were complete. This represents over 60 percent of the total interviews; when broken down by sample type it reveals that 81 percent of the voucher parent probability interviews and 69 percent of the block quota interviews were complete.

On November 24, FRC received the names for two additional subsamples of interviews to be obtained: one subsample represented parents drawn on a probability basis in the nonvoucher area from the six schools involved in the RECAP attendance project: Matheson, Fischer, Hubbard, Shields, Painter, and Conniff. The other subsample represented changers, those parents who changed the school in the voucher area that one of their children attended.

By November 27, 526 of the 600 parent interviews and 510 of the 620 block quota interviews were in hand. In addition, nine of the changers and 28 nonvoucher probability parents had also been interviewed. The percentage increase in completed interviews from the second to the third week decreased because, in general, interviews completed at this time represented second, third, fourth, or fifth callbacks in the probability sample, and in the block quota sample represented interviews with respondents that had to be located in alternate blocks since the original block had been exhausted in the quota search. This decrease does not represent a lack of efficiency; it demonstrates the increase in difficulty which faced interviewers in obtaining completed interviews.

Table VI-B. 2

CUMULATIVE NUMBER OF COMPLETED INTERVIEWS BY WEEX AND BY SAMPLE TYPE

\begin{tabular}{l|r|r|r|r|r}
\hline Sample & $\begin{array}{r}\text { Nov. 4- } \\
\text { Nov. 11 }\end{array}$ & $\begin{array}{l}\text { Nov. 12- } \\
\text { Nov. 19 }\end{array}$ & $\begin{array}{l}\text { Nov. 20- } \\
\text { Nov. 27 }\end{array}$ & $\begin{array}{r}\text { Nov. 28- } \\
\text { Dec. 4 }\end{array}$ & $\begin{array}{l}\text { Dec. 5- } \\
\text { Dec. 12 }\end{array}$ \\
\hline $\begin{array}{l}\text { Voucher parent proba- } \\
\text { bility sample }\end{array}$ & 333 & 485 & 526 & 551 & 600 \\
$\begin{array}{l}\text { Changer sample } \\
\begin{array}{l}\text { Nonvoucher parent } \\
\text { probability sample }\end{array}\end{array}$ & 0 & 0 & 9 & 45 & 56 \\
Block quota sample & 231 & 410 & 510 & 561 & 620 \\
$\quad$ Total & 564 & 895 & 1073 & 1267 & 1460 \\
\hline
\end{tabular}


On December 4, at the end of one month, 1267 of the 1460 interviews had been completed, which represented over 90 percent of the parent probability sample, over 90 percent of the block quota sample, 88 percent of the changer sample, and 51 percent of the nonvoucher parent probability sample. During the final week, from December 5 to December 12, interviewers continued to hunt the "hard to find" respondents in the probability sample and to search for "hard to locate" respondents in the block quota sample. At times in this latter case, interviewers had exhausted two, three, or four alternate blocks before they found their last block quota respondent.

\section{THE SAMPLES IN DETAIL}

\section{The Probability Sample}

In each of the six voucher schools a sample was selected such that it would proportionately represent the total school population and within each school stratification of the sample was such that blacks, Mexican-Americans, and other whites were represented in their proportion of the school population. In total, 600 families were to be interviewed in all of the voucher schools, and to obtain an 80 percent response rate we drew 720 parent names. Table VI-B.3 presents a detailed breakdown of the parent probability samples. We see that for the parent probability sample, 174 of the 600 interviewers were obtained on an initial call and 165 from

Table VI-B. 3

PROBABILITY SAMPLE TYPE BY INTERVIEW DISPOSITION

\begin{tabular}{|c|c|c|c|c|c|c|c|c|c|}
\hline \multirow[b]{2}{*}{ Item } & \multicolumn{4}{|c|}{ Voucher Probability Sample } & \multirow[b]{2}{*}{ Changers } & \multicolumn{4}{|c|}{ Nonvoucher Probability Sample } \\
\hline & Total & $\begin{array}{l}\text { Other } \\
\text { White }\end{array}$ & Black & $\begin{array}{l}\text { Mexican- } \\
\text { American }\end{array}$ & & Total & $\begin{array}{l}\text { Other } \\
\text { White }\end{array}$ & Black & $\begin{array}{l}\text { Mexican- } \\
\text { American }\end{array}$ \\
\hline Total complete Interviews & 600 & 244 & 56 & 300 & 56 & 184 & 62 & 13 & 104 \\
\hline First call & 174 & 84 & 16 & 74 & 13 & 60 & 26 & 4 & 30 \\
\hline Second call & 165 & 54 & 13 & 98 & 16 & 36 & 12 & 4 & 20 \\
\hline Third call & 119 & 47 & 15 & 57 & 10 & 29 & 8 & 2 & 19 \\
\hline Fourth call & 57 & 23 & 3 & 31 & 6 & 26 & 5 & 1 & 17 \\
\hline Fifth call & 35 & 15 & 2 & 15 & 4 & 14 & 2 & 2 & 8 \\
\hline Sixth call & 16 & 8 & 1 & 7 & 0 & 6 & 3 & 0 & 3 \\
\hline Seventh call & 18 & 5 & 4 & 9 & 3 & 6 & 3 & 0 & 3 \\
\hline E1ghth call & 16 & 5 & 2 & 9 & 2 & 7 & 3 & 0 & 4 \\
\hline Refusals and terminations & 29 & & & & 11 & 16 & & & \\
\hline $\begin{array}{l}\text { Language barrier (spoke only } \\
\text { Samoan) }\end{array}$ & 4 & & & & 0 & 0 & & & \\
\hline Permanently not at home & 7 & & & & 5 & 8 & & & \\
\hline Children no longer in school & 4 & & & & 1 & 1 & & & \\
\hline Previously intervlewed & 18 & & & & 21 & 17 & & & \\
\hline Moved from address & 58 & & & & 15 & 50 & & & \\
\hline Total names & 720 & 286 & 67 & 363 & 99 & 276 & & & \\
\hline $\begin{array}{l}\text { Inttial refusals successfully } \\
\text { interviewed }\end{array}$ & 19 & & & & 3 & 3 & & & \\
\hline
\end{tabular}


the first call-back. An additional 119 interviews resulted from a second call-back. This represents 468 of the 600 respondents. However, among other white respondents, interviewing a respondent on the first, second, or third call was proportionately higher than among Mexican-Americans; comparisons of the black sample, because of its small size, are hard to interpret in these terms.

We also see that interviewers obtained a total of 29 outright refusals. In fact, they initially had 48 outright refusals, but through the effective reassignment of initial refusals to other interviewers, FRC reduced this number from 48 to 29 . Additionally, we see that 58 of the 720 names originally given to FRC for the parent probability sample had moved from the address given and could not be located, and 18 of the parents in the probability sample had been previously interviewed in another subsample. The latter usually resulted because their residence address was in the nonvoucher areas. If we exclude those who had been previously interviewed and those who had moved from their current address, we see that the response rate in the parent probability sample is 93 percent. And, without excluding them from the sample, we see that the overall response rate is 82.7 percent. Moreover, the response rate appears to be constant across ethnic groups, other white, black, or Mexican-American. Similar analysis of the changer sample and the nonvoucher probability sample are also presented in Table VI-B.3. It is interesting to note that in the nonvoucher probability sample the level of geographical mobility of parents is exceptionally high. Fifty of the 276 names presented to FRC were no longer living at their current address. Looking at the response rates in the changer and nonvoucher probability samples, we see that in both cases more than 80 percent of the usable names were interviewed, excluding those who had moved or been previously interviewed.

\section{The Block Quota Sample}

The block quota sample, in fact,-contains two separate block quota samples. There was a block quota sample of nonparents in the voucher area, and a block quota sample of parents and nonparents in the nonvoucher area. In the nonvoucher area, respondents were interviewed whether they were a parent or not, such that parents fall within the sample in proportion to the overall population. This is to say that we did not screen on parents and nonparents.

The quota types for the block quota sample were as follows:

1. Males under 40

2. Males over 40

3. Working women

4. Nonworking women

In addition, as a function of the ethnic composition of the block, either other white, Mexican-American or mixed, an ethnic quota was set such that in the mixed blocks each of the quota types had an equal probability of being either MexicanAmerican or other white. In the voucher area we see that interviewers obtained interviews from 242 nonparents and 258 parents. (See Table VI-B.4.) This reflects their distribution in the total population. Comparing the nonvoucher parents and the nonvoucher nonparents, we see that the nonvoucher nonparents are disproportionately male, 55 percent, and disproportionately older, 54 percent. This results from the fact that we did not have an explicit quota on parents, and in fact is probably more demographically representative of the population of nonparents and parents than equal numbers of each. In the voucher area, the block quota sample of nonparents by definition is fixed at one-fourth for each of the quota types. This 
Table VI-B.4

BLOCK QUOTA SAMPLE TYPE BY QUOTA TYPE, WITH AND WITHOUT A CONTROL FOR ETHNICITY

\begin{tabular}{|c|c|c|c|c|c|c|c|c|c|c|c|c|}
\hline \multirow[b]{2}{*}{ Sample } & \multicolumn{4}{|c|}{ Voucher Nonparents } & \multicolumn{4}{|c|}{ Nonvoucher Nonparents } & \multicolumn{4}{|c|}{ Nonvoucher Parents } \\
\hline & Total & $\begin{array}{l}\text { Other } \\
\text { White }\end{array}$ & Black & $M-A^{a}$ & Total & $\begin{array}{l}\text { Other } \\
\text { White }\end{array}$ & Black & $M-A^{a}$ & Total & $\begin{array}{l}\text { Other } \\
\text { White }\end{array}$ & Black & $M-A^{a}$ \\
\hline Males under 40 & 25.0 & 20.0 & 16.7 & 27.8 & 23.6 & 21.8 & 40.0 & 24.1 & 26.0 & 26.5 & 14.3 & 26.8 \\
\hline Males over 40 & 25.0 & 37.1 & 16.7 & 20.3 & 31.4 & 29.8 & 20.0 & 34.3 & 19.8 & 22.5 & 0 & 20.1 \\
\hline Workfing women & 25.0 & 20.0 & 50.0 & 25.3 & 22.7 & 25.0 & 20.0 & 19.4 & 26.7 & 22.5 & 42.9 & 27.4 \\
\hline Nonworking women & 25.0 & 22.9 & 16.6 & 26.6 & 22.3 & 23.4 & 10.0 & 22.2 & 27.5 & 28.8 & 42.9 & 25.6 \\
\hline$N=$ & 120 & 35 & 6 & 79 & 242 & 124 & 10 & 108 & 258 & 80 & 14 & 164 \\
\hline $\begin{array}{c}\text { Ethnic percentage } \\
\text { of sample type }\end{array}$ & & 29.0 & 5.0 & 66.0 & & 51.2 & 4.1 & 44.7 & & 31.0 & 5.4 & 63.6 \\
\hline
\end{tabular}

$a_{M-A}=$ Mexican-American.

may include too many younger nonparents in the voucher nonparent sample. But this was to be expected because of the sampling method.

Alternate Blocks. Initially for the block quota samples we had 172 sampling units. This number was reduced by 17 when we eliminated those sampling units which fell outside the voucher and nonvoucher area geographically and those that had too few housing units within their boundaries. In total, 155 sampling units remained. These 155 sampling units fell within 118 blocks. The reason for the difference between the number of sampling units and blocks is that in some cases more than four interviews (between eight and twenty-four) were obtained per block. This was to insure that large blocks would be represented in the sample in proportion to their size.

One of the major problems with this block quota sample was the inordinate number of alternate blocks that it required. In fact, to obtain the required number of interviews from the original 118 blocks we had to draw 130 alternate blocks. Usually in block quota samples, no more than 20 percent of the original blocks need alternates, and in this case the additional 130 blocks brings the total number of blocks required for this sample to 248 . Given that there were only 280 usable blocks in voucher and nonvoucher areas, it became apparent to us that we had saturated the area in terms of a block quota sample. Employing this number of blocks out of the total severely limited the efficiency with which alternates could be assigned and with which interviewers could obtain interviews. A closer analysis of the alternates reveals that 86 of the sampling units required at least one alternate. For another 53 blocks a second alternate was required. For 16 blocks three alternates were required and for five blocks, four or more alternate blocks were required. The large number of alternate blocks also helps to explain the extended time it took the interviewers to complete many of their block quota assignments.

From another point of view we see that interviewers needed fewer alternates in the other white blocks than in the mixed and Mexican-American blocks. It was also hard to assign alternates in the mixed or Mexican-American blocks since the classification of blocks was based on the number of Spanish surnames, not an actual count of Mexican-Americans. This may account for the longer period of time it took the interviewers to complete interviews in the Mexican-American and mixed blocks. 


\section{ETHNIC DISTRIBUTION}

The question of how ethnically representative each of the subsamples is remains an important one. Table VI-B.5 presents the distribution of respondents in the total population of other whites, blacks, and Mexican-American families. In the probability sample we see that 39 percent of the families were other white, 9 percent black, and 52 percent Mexican-American. It is important to note that we sampled parents in the voucher schools in proportion to the ethnic percentage of the number of families in the school population, not the number of students. Using the family as the sampling unit rather than the student increases the percentage of other whites, since Mexican-American families tend to have more children per family and thus overrepresent families in the student population. The parent probability sample matches the population from which it was drawn quite closely. In terms of the original 720 names drawn, less than one percentage point deviation exists from their percentages in the population percentages. In terms of completed interviews, we see that other whites are about 1 percent more in the completed interviews and Mexican-American families are about 1 percent less.

In the nonvoucher area, the probability sample of parents was drawn on the basis of student lists, not family lists. This means that we expected a higher proportion of Mexican-American families to appear than if we had used a family list. In fact, this was the case. The ethnic percentages of nonvoucher parents in the school population based on student percentages were: 32.3 percent other white, 10.1 percent black, and 56.7 percent Mexican-American. The ethnic percentages of the sample of completed parents in the nonvoucher area were: 34.6 percent other white, 7.3 percent black, and 58.1 percent Mexican-American. These slight deviations from the population percentages do not appear to bias the sample.

In some cases the block quota sample is very accurate; in other cases it may be less so. In terms of the parent block quota sample in the nonvoucher area, 31 percent of the respondents were other white, 5.4 percent black, and 63.6 percent MexicanAmerican. The difference between the 5.4 percent black obtained and the 10.1 percent expected in terms of the student population probably results from the fact that blacks were not a prescribed quota assignment, and given the choice, interviewers sought other respondents. In terms of nonparents in the nonvoucher area, 51.2

Table VI-B.5

ETHNIC DISTRIBUTIONS OF SURVEY SAMPLES

\begin{tabular}{l|r|r|r|r}
\hline \multicolumn{1}{|c|}{ Sample } & $\begin{array}{r}\text { Total } \\
\mathrm{N}\end{array}$ & $\begin{array}{r}\text { Other } \\
\text { White } \\
(\%)\end{array}$ & $\begin{array}{c}\text { Black } \\
(\%)\end{array}$ & $\begin{array}{c}\text { Mexican- } \\
\text { American } \\
(\%)\end{array}$ \\
\hline Parents from voucher school family 11st & 2153 & 39.0 & 9.0 & 52.2 \\
Parent probability sample & 720 & 39.8 & 9.1 & 51.1 \\
Completed parent interviews & 600 & 40.4 & 9.4 & 50.2 \\
Changer sample & 54 & 49.1 & 11.8 & 39.1 \\
Voucher parent block quota sample & 120 & 29.2 & 5.0 & 65.8 \\
Parents from selected nonvoucher school & & & & \\
student list & 4053 & 32.2 & 10.1 & 56.7 \\
Parent probability sample & 184 & 34.6 & 7.3 & 58.1 \\
Parent block quota sample & 258 & 31.0 & 5.4 & 63.6 \\
Nonparent block quota sample & 242 & 51.2 & 4.2 & 44.6 \\
\hline
\end{tabular}


percent were other white, 4.1 percent black, and 44.6 percent Mexican-American. The higher proportion of other whites in this sample probably indicates that other whites living in the nonvoucher area are in general older and thus less likely to have children in school. It also suggests that the nonparent sample in the nonvoucher area is in fact more other white than Mexican-American, unlike the nonparent sample in the voucher area.

Nonparents in the voucher area, the last of the block quota samples, were only 29.5 percent other white, 5 percent black, and 65.8 percent Mexican-American. This high percentage of Mexican-Americans may well be explained by the classification of blocks on the basis of apparent Spanish surnames extracted from the Polk directory and the fixed age quotas for males. A closer look at the demography of the voucher area in San Jose reveals that in this area of the city there are several Portuguese and Cuban families. These were included in the Spanish surname list rather than in the other white list in the block classification process. Thus, we sampled disproportionately more all Mexican-American blocks in this area than we might have if we had had a cleaner demographic classification of the blocks. This helps to explain the higher percentage of Mexican-Americans in the voucher nonparent sample.

The comparison of the parent probability sample in the nonvoucher area and the parent block quota sample in the nonvoucher area reflects well on the block quota technique in terms of insuring demographic representativeness. We see that the percentages usually deviate by less than 3 percent. Some of this might be explained by the fact that the parent block quota sample is representative of the entire nonvoucher area, whereas the parent probability sample is representative of the entire catchment areas of six schools in the RECAP attendance project. Further analysis of these differences is necessary before any strong conclusions can be drawn. 


\title{
Appendix VI-C STUDENT TRANSFERS
}

\author{
by Robert T. Riley
}

This appendix:

- Describes the transfer process at different times during the year.

- Defines student transfers not related to parents' exercising their voucher option.

- Separates a school's enrollment into various components and specifies the socalled legitimate transfer population.

- Analyzes an administrative transfer pattern that occurred in the summer of 1972.

\section{THE TRANSFER PROCESS}

The time of the year structures the transfer process. When a parent chooses to transfer a child, it is assumed that he has accurate and up-to-date information about other program offerings and their availability (they have not been closed out or do not have a waiting list). A parent must also file a request for transfer in the form of an application in the spring or "transfer request" at other times during the school year. Moreover, a parent must contact school officials either at the central office during the summer, or at the school during the year to transfer a child. This contact with school officials usually involves contact with a parent counselor who will inform the parent about program offerings and their availability and often will help the parent to file the transfer form.

In summary, to transfer a child a parent must have acquired information about other programs, have contacted school officials directly or indirectly, and have completed an administrative procedure. On the basis of these steps involved in the transfer process, transfers can be divided into three types: application transfers, summer transfers, and school year transfers.

\section{Application Transfers}

In the spring of each year, usually by the end of May, a parent must file an enrollment form for each child in a voucher school, which enrolls a child in a program for the next school year. A parent must complete this application, whether his child remains in the same program or changes programs. Many program changes that occur at this time are system related, i.e., involve graduation, etc.

On the enrollment form a parent gives three program choices for his child; a parent with a child in a program during the current school year is guaranteed a place for his child in the same program for the next year. However, if a parent wishes to enroll his child in another program for the next year, he gives three program preferences. Usually parents receive their first choice.

During the application period, information about program offerings for the next year is accurate and up to date. Parents have received information about the various programs from the school system during the month prior to the application deadline; they do not have to seek it out. To receive more information about programs they 
contact the staff of the school in which they have children enrolled or in whose catchment area they reside; they do not have to contact the central office. Parent counselors, who are available at the school during this time of year, have information about all available programs, not just the ones in that school.

Application transfers occur at a time when accurate information is readily available and thus require the least effort on the part of parents and the least administrative effort and record keeping on the part of school system. Moreover, completion of application transfers requires a minimal amount of contact with school staff or parent counselors.

\section{Summer Transfers}

A summer transfer occurs during the period between June and September after an application has been filed. Parents seeking a transfer during the summer must go to the school system's central office, not to a school, to complete the process. At the central office a parent must complete a "transfer request" form that negates his application's choice. Parent counselors are available there with accurate and up-todate information about the available program offerings. Some programs may be closed out because they are filled, and others may have been eliminated. Seeking a transfer in the summer requires more effort than at the time of application, and the range of choices may be reduced.

\section{School Year Transfers}

Transferring a child during the school year requires the completion of a transfer request form and contact with a school official or parent counselor at the school, not at the central office. Information about the range of all program offerings is less accurate and less available in the school year than at the time of application or during the summer. If a parent changes schools as well as programs, then he may have to contact the school staff at two schools. Transfers during the school year also involve disruption of the child's daily routine. Changing programs and, in particular, changing schools means that a child's peer group will change, and the child may feeel initially socially isolated.

In summary, application and summer transfers require less effort and involve less disruption than school year transfers. The transfer process is more demanding in the school year. As a result it is reasonable to expect the transfer activity to be greater at the time of application and during the summer than during the school year.

\section{NONVOUCHER-RELATED STUDENT TRANSFERS}

Not all transfer activity can be attributed to parents exercising their voucher options to change the programs or schools of their children. A legitimate transfer involves a change in programs by a student that can only be attributed to parents taking advantage of their voucher option, not to other factors such as intra-district mobility, graduation, program discontinuation, or administrative decisions by school officials. 


\section{SYSTEM-RELATED TRANSFERS}

Most student transfers unrelated to parents' exercising their voucher option occur over the summer or because of residential mobility; a few result from administrative decisions of school officials, and some appear in the data files because of clerical errors. Transfer activity over the summer usually involves the structure of the school or program-a student has completed its highest grade and must enter a new program in the fall. The time of year affects the definition of many transfers as voucher related or not; most student transfers that occur during the summer are system related, i.e., they depend on the structure of schools and existed before the advent of vouchers. The following system-related transfers are of interest:

\section{Graduation}

These are transfers that occur when a student completes an elementary school and enters a middle school.

\section{Feeder Schools}

Nonvoucher feeder schools provide the catchment areas for some of the voucher middle schools. Students enrolled in nonvoucher elementary schools last year who have had to transfer into middle schools participating in the demonstration this year are called "nonvoucher feeder school entrants."

\section{Program Discontinuation}

A school may discontinue a program and force all children to enter new programs for the next year. This has not occurred in Alum Rock, but it is a possibility.

\section{Special Education}

In the voucher schools about 200 students are in special education classes. Transfers involving movement to or from a "special ed" class are not counted as "legitimate" transfers.

\section{Kindergarten Graduation}

Some voucher schools offer a program called kindergarten. After a child completes his year in kindergarten, a parent has to choose a new program. However, if kindergarten is a grade offered as part of a larger program, and a parent chooses to enroll his child in another program's first grade, then the transfer would be a voucher-related transfer.

\section{Kindergarten} fers.

Students who enter kindergarten are not considered "legitimate" voucher trans-

\section{MOBILITY-RELATED CHANGES}

Families change residences continually during the school year; some residential 
mobility occurs within the confines of the school district; other families move into the school district from other communities, and some families move from the district to other communities. Student transfers associated with residential mobility affect the enrollments of the voucher schools, but these transfers cannot be attributed to vouchers.

\section{Intradistrict Mobility Changes}

When a family moves within the school district beyond the catchment area of the school associated with its residence, then the parent has the option of leaving his child in the school associated with his old residence, or transferring his child to the catchment area associated with his new residence. In this case, transferring a child to the new school would not be a legitimate transfer, if it is only done for mobility reasons, even though the child's school may change. And, if a parent leaves his child in his old school, it might be considered a legitimate transfer.

\section{New Entrants}

These are families that move to Alum Rock and have to enter a child in a school. They are transfers from outside the district.

\section{Administrative Transfers}

The actions of school officials account for some types of student transfer activity. Some administrative transfers result from the actions of officials directed toward schools, while others result from the actions of school officials directed toward parents directly.

\section{Catchment Area Changes}

If school officials change the catchment area of a school, it is possible that some residents of nonvoucher catchment areas will find themselves in voucher catchment areas with the options of education vouchers now open to them. School transfers of this type can only occur in the summer.

\section{"Out Sneakers"}

Some parents in the voucher area have made arrangements for their children to attend nonvoucher schools even though they should be enrolled in voucher schools.

\section{"In Sneakers"}

In Alum Rock it appears that a limited number of families living in the nonvoucher area have enrolled their children in voucher schools, through special arrangements with the school district, or through misrepresentation of their addresses.

\section{Provisional Placement}

Provisional placement students may be temporarily placed in programs, i.e., they may be placed on a waiting list for some program if they did not receive the 
first program choice, and provisionally placed in another, until space becomes available in the first-choice program. When this happens, because of the recordkeeping system it first appears as if a transfer has been made by a parent, although the school has brought about the transfer.

A school's 1973 enrollment can be divided into eight components, taking into account the differences in transfer types previously described. These are:

- Stayer: A student in the same school as the previous year without a program change.

- Program changer: A student in the same school as the previous year with a change in program related to the use of vouchers.

- School changer: A student who changed school because of parental utilization of a voucher option.

- Kindergarten: A student entering kindergarten.

- Graduation: A student in a new program because in the previous school year he was enrolled in a school or a program's highest grade. These may be kindergarten graduates.

- Feeder: A student scheduled to enter voucher middle school from nonvoucher elementary school due to middle school catchment area definitions. These students did not have to enter the middle school associated with their nonvoucher elementary school, but could select any program available for their grade level.

- New entrant: A student from a family who has moved to the district from another school district and is not enrolled in kindergarten.

- In-sneaker: A student who resides in the catchment area of a nonvoucher school, not a middle school student, who attends a voucher school through a special arrangement.

Separating a school's enrollment into these components serves several purposes:

1. It demonstrates that several factors affect changes in a school's enrollment other than voucher-related transfers.

2. It provides an estimate of the inmigration into the school district.

3. It shows how system-related changes, graduation, etc., affect middle school enrollments.

4. It indicates the extent of within-school transfer activity by program changers.

\section{ADMINISTRATIVE TRANSFERS IN THE SUMMER OF 1972}

One particular type of administrative transfer that occurred in the summer of 1972 clearly shows how the level of transfer activity associated with parents' exercising their voucher options may be artificially inflated by the decisions of school personnel.

In the summer of 1972 a distinctive transfer pattern emerged:

1. Parents applied for and were assigned to the Cassell school.

2. Over the summer parents had their children transferred to the McCollam school.

3. By the time school began, students were back in the Cassell school.

This transfer pattern characterized 80 students in 55 families. At first glance it seems that a significant number of parents were utilizing their voucher option to pressure the Cassell school system and that Cassell school responded to parental 
pressure to draw back students it had lost to the McCollam school. This was not the case. The school system had reassigned the students, not once, but twice. When parents were asked about this change in the fall survey they claimed they never changed their children's school. This is a good example of the way in which estimates of the extent of transfer activity can be inflated. Whenever possible, estimates of transfer activity by parents and students have to be corrected for transfers not directly related to the voucher option. In particular, student transfers that resulted from administrative decisions of school officials have to be eliminated. 


\title{
Appendix VI-D \\ SOURCES OF INFORMATION ABOUT VOUCHERS
}

\author{
by R. Gary Bridge
}

This appendix analyzes in some detail the sources of information about the voucher program that parents used. The purpose is to find out how informed parents became informed, as a function of ethnicity and social class. Only "aware parents" are included in this analysis: that set of parents who knew about the voucher program in Alum Rock.

As mentioned earlier, 83 percent of the parents knew about the voucher model in Alum Rock in the fall of 1972. Eleven possible sources of information were identified:

1. Radio and TV

2. Newspapers

3. Materials received from schools

4. School bulletins

5. PTA meetings

6. Parent meetings

7. Board of Education meetings

8. Talks with children

9. Talks with other parents, relatives, friends, and neighbors

10. Talks with teachers and principals

11. Talks with school counselors and advisors

Parents were asked to indicate which sources they used. The average voucher parent received information from four sources, but the number of sources used, like awareness of the voucher model, was related to education and ethnicity. Anglo respondents used the most sources of information (4.6), and Mexican-Americans the fewest (3.2).

Table VI-D.1 indicates the frequency with which parents used each source of information. The one most frequently cited was printed school material; over fourfifths of the respondents ( 81 percent) learned something about vouchers from official school publications. (The information distribution system in the first year relied on delivery of information in person by parent counselors to each household; it became known as the "doorstep" delivery system.)

About 45 percent of the parents cited talks with teachers and neighbors. About a third learned about vouchers through talks with children, talks with parent counselors, and attendance at PTA and parent meetings. Radio and TV provided information to about one-fifth of the parents. Board of Education meetings were the least used source of information; only 6.7 percent of aware parents attended any of those meetings.

\section{Personalization and Involvement}

The first column of Table VI-D.1 groups the eleven sources of information about 
Table VI-D. 1

PARENTS' SOURCES OF INFORMATION ABOUT VOUCHERS, BY ETHNICITY, 1972

(In percent)

\begin{tabular}{|c|c|c|c|c|c|c|}
\hline \multirow[b]{2}{*}{ Category } & \multirow[b]{2}{*}{ Specific Source } & \multirow[b]{2}{*}{$\begin{array}{l}\text { Total } \\
(495)\end{array}$} & \multirow[b]{2}{*}{$\begin{array}{l}\text { Anglo } \\
(240)\end{array}$} & \multirow[b]{2}{*}{$\begin{array}{r}\text { B1ack } \\
(56)\end{array}$} & \multicolumn{2}{|c|}{$\begin{array}{l}\text { Mexican-American, } \\
\text { Interviewed in: }\end{array}$} \\
\hline & & & & & $\begin{array}{c}\text { English } \\
(143)\end{array}$ & $\begin{array}{l}\text { Spantsh } \\
(56)\end{array}$ \\
\hline Mass med1a & $\begin{array}{l}\text { Radio and TV } \\
\text { Newspapers }\end{array}$ & $\begin{array}{l}19.6 \\
43.5\end{array}$ & $\begin{array}{l}23.2 \\
49.0\end{array}$ & $\begin{array}{l}16.0 \\
37.5\end{array}$ & $\begin{array}{l}15.4 \\
39.9\end{array}$ & $\begin{array}{l}17.9 \\
35.7\end{array}$ \\
\hline School publications & $\begin{array}{l}\text { School materials } \\
\text { School bulletins }\end{array}$ & $\begin{array}{l}81.0 \\
49.6\end{array}$ & $\begin{array}{l}82.0 \\
57.7\end{array}$ & $\begin{array}{l}84.0 \\
39.3\end{array}$ & $\begin{array}{l}82.5 \\
44.1\end{array}$ & $\begin{array}{l}69.6 \\
39.3\end{array}$ \\
\hline Formal meetings & $\begin{array}{l}\text { PTA meetings } \\
\text { Parent meetings } \\
\text { Board of Education meetings }\end{array}$ & $\begin{array}{r}29.4 \\
31.5 \\
6.7\end{array}$ & $\begin{array}{r}34.0 \\
37.8 \\
8.7\end{array}$ & $\begin{array}{r}17.9 \\
25.0 \\
3.6\end{array}$ & $\begin{array}{r}28.0 \\
23.8 \\
1.4\end{array}$ & $\begin{array}{r}25.0 \\
30.4 \\
1.8\end{array}$ \\
\hline $\begin{array}{l}\text { Talks with } \\
\text { nonschool people }\end{array}$ & $\begin{array}{l}\text { Talks with children } \\
\text { Talks with frlends }\end{array}$ & $\begin{array}{l}25.8 \\
42.3\end{array}$ & $\begin{array}{l}28.2 \\
47.7\end{array}$ & $\begin{array}{l}21.4 \\
44.6\end{array}$ & $\begin{array}{l}23.8 \\
37.0\end{array}$ & $\begin{array}{l}25.0 \\
30.3\end{array}$ \\
\hline $\begin{array}{l}\text { Talks with } \\
\text { school staff }\end{array}$ & $\begin{array}{l}\text { Talks with teachers, principals } \\
\text { Talks with counselors }\end{array}$ & $\begin{array}{l}46.8 \\
31.5\end{array}$ & $\begin{array}{l}48.5 \\
37.8\end{array}$ & $\begin{array}{l}48.2 \\
25.0\end{array}$ & $\begin{array}{l}41.9 \\
42.0\end{array}$ & $\begin{array}{l}50.0 \\
39.3\end{array}$ \\
\hline
\end{tabular}

vouchers into five categories according to their degree of personalization. Of course, a correlate of personalization is active involvement, and these two dimensions cannot be pulled apart easily. For example, it is easier to ignore a newspaper article than it is to ignore a speaker in a face-to-face conversation; and, in addition to demanding more attention, face-to-face communications can be aimed precisely at the listener or changed according to the listener's reactions. Newspapers, in contrast, are aimed at a general audience, and direct interaction is impossible. At one end of the personalization-involvement dimension we have information gathered from the mass media: newspapers, radio, and TV. These are the least personalized and involving sources of information. At the other end are face-to-face conversations, the most personalized and involving type of communication. We have broken this general category into two subcategories: talks with nonschool people (e.g., neighbors, children) and talks with school staff (e.g., teachers, principals, counselors).

When we use these five categories instead of the original eleven basic sources, we find (Table VI-D.2) that printed materials from the schools were clearly the most widely used source of information about vouchers ( 86.7 percent), and formal meetings the least used.

The ethnic groups varied in how many sources of information they used and, in general, they also varied in the types of information they received; however, they differed very little in their reported exposure to the two major sources of information, talks with teachers (and principals) and printed school materials.

The first thing that can be seen in Table VI-D.1 is that with the exception of one source (talks with teachers), Anglo parents were the most likely to have used a particular source. They were more likely than other parents to have learned about vouchers through radio and TV broadcasts, newspapers, school bulletins, attend- 
Table VI-D.2

PARENTS' INFORMATION ABOUT VOUCHERS, BY INFORMATION

CATEGORY AND ETHNICITY, 1972

\begin{tabular}{|c|c|c|c|c|c|}
\hline \multirow[b]{2}{*}{ Category } & \multirow[b]{2}{*}{$\begin{array}{l}\text { Total } \\
(495)\end{array}$} & \multirow[b]{2}{*}{$\begin{array}{l}\text { Anglo } \\
(240)\end{array}$} & \multirow[b]{2}{*}{$\begin{array}{r}\text { Black } \\
(56)\end{array}$} & \multicolumn{2}{|c|}{$\begin{array}{l}\text { Mexican-American, } \\
\text { Interviewed in: }\end{array}$} \\
\hline & & & & $\begin{array}{c}\text { Engl1sh } \\
(143)\end{array}$ & $\begin{array}{l}\text { Spanish } \\
\text { (56) }\end{array}$ \\
\hline Mass media & 47.6 & 53.1 & 41.1 & 43.4 & 41.1 \\
\hline School publications & 86.7 & 88.0 & 87.5 & 88.1 & 76.8 \\
\hline Formal meet1ngs & 40.9 & 47.3 & 28.6 & 35.7 & 39.3 \\
\hline Talks with nonschool people & 53.8 & 57.3 & 55.4 & 51.0 & 44.6 \\
\hline Talks with school staff & 65.9 & 68.0 & 64.3 & 61.5 & 69.6 \\
\hline
\end{tabular}

ance at parent and PTA meetings, Board of Education meetings, and talks with their children and friends. For two categories only-talks with counselors, and school materials-Mexican-Americans and blacks, respectively, were about as likely to use that source as were Anglos.

It seems logical that most Mexican-Americans who speak little or no English would be prevented from easy access to some sources of voucher information (e.g., radio and TV broadcasts are mostly in English), and if language is indeed a constraint on communications, we should find that English-speaking and non-Englishspeaking Chicanos used markedly different sources of information. The data in Table VI-D.1 do not support this notion, however. Parents interviewed in Spanish were just as likely as those interviewed in English to have talked with school personnel, to have attended PTA and parent meetings, and to have learned about vouchers through radio and TV. In fact, those who speak predominantly (or only) Spanish in the home were more likely to have talked with teachers than were English-speaking respondents. Language may have been a constraint only in relation to the printed word: printed school materials, school newsletters, and newspapers.

\section{MOST HELPFUL AND LEAST HELPFUL INFORMATION SOURCES}

The frequency of a person's exposture to an information source does not necessarily reflect its influence on his decisionmaking. To learn which sources they valued most, parents were asked to review the original list of eleven sources and answer which they found most helpful (Q40B) and least helpful (Q40C). (This item was asked only of respondents who reported having used more than one source of information. Of course, for those parents who only cited two sources, the term "least helpful" source is probably not very meaningful.) Table VI-D.3 summarizes their responses. Printed school material ranked highest in helpfulness, with 30.4 percent of the total vote. Talks with teachers, principals, and counselors also ranked high (around 20 percent). The other sources received scattered votes.

Newspapers, talks with friends and children, and-surprisingly-printed school materials were all rated as least helpful by at least 14 percent of the parents. Why printed school materials should be rated so high on both the most and least useful 
Table VI-D. 3

PARENTS' RATINGS OF MOST AND LEAST HELPFUL SOURCES OF INFORMATION, BY ETHNICITY, 1972

\begin{tabular}{|c|c|c|c|c|c|c|c|c|}
\hline \multirow[b]{2}{*}{ Source } & \multicolumn{4}{|c|}{ Most Helpful Source (Q40B) } & \multicolumn{4}{|c|}{ Least Helpful Source (Q40C) } \\
\hline & $\begin{array}{l}\text { Total } \\
(447)\end{array}$ & $\begin{array}{l}\text { White } \\
(220)\end{array}$ & $\begin{array}{r}\text { Black } \\
(52)\end{array}$ & $\begin{array}{c}\text { Mexican- } \\
\text { American } \\
\text { (175) }\end{array}$ & $\begin{array}{l}\text { Tota1 } \\
(419)\end{array}$ & $\begin{array}{l}\text { White } \\
(211)\end{array}$ & $\begin{array}{r}\text { Black } \\
(47)\end{array}$ & $\begin{array}{l}\text { Mexican- } \\
\text { American } \\
\text { (161) }\end{array}$ \\
\hline Radio and TV & 1.1 & 0.9 & 3.8 & 0.6 & 10.5 & 10.9 & 6.5 & 11.2 \\
\hline Newspapers & 2.9 & 2.7 & 3.8 & 2.9 & 18.4 & 18.5 & 10.1 & 18.0 \\
\hline School materials & 30.4 & 30.0 & 34.6 & 29.7 & 14.3 & 11.4 & 17.0 & 17.4 \\
\hline School bulletins & 4.9 & 9.1 & 5.8 & 5.7 & 9.5 & 9.5 & 12.8 & 8.7 \\
\hline PTA meetings & 4.3 & 5.9 & 0.0 & 3.4 & 5.0 & 4.3 & 0.0 & 7.5 \\
\hline Parent meetings & 6.5 & 7.3 & 3.8 & 6.3 & 2.9 & 3.8 & 2.1 & 1.9 \\
\hline Board of Education meetings & 1.8 & 1.8 & 0.0 & 2.3 & 0.7 & 0.9 & 0.0 & 0.6 \\
\hline Talks with children & 1.8 & 1.4 & 1.9 & 2.3 & 14.8 & 18.5 & 14.9 & 9.9 \\
\hline Talks with friends & 6.0 & 7.3 & 7.7 & 3.7 & 16.2 & 14.2 & 23.4 & 16.8 \\
\hline Talks with teachers, princlpals & 19.7 & 19.1 & .17 .3 & 21.1 & 4.1 & 4.3 & 2.1 & 4.3 \\
\hline Talks with counselors & 19.9 & 19.5 & 21.2 & 20.0 & 3.6 & 3.8 & 2.1 & 3.7 \\
\hline
\end{tabular}

lists is not clear; 30 percent of the sample thought this was the best source of information, and here we see that half that number, 15 percent, felt just the opposite. The explanation may be partly cultural. Mexican-Americans interviewed in Spanish were almost twice as likely as whites to rate printed materials as least helpful; and fewer of them than of other ethnic subgroups rated school materials as most helpful.

It is not safe to attribute those differences to language, however-unfamiliarity with English-since the schools furnished abundant material printed in Spanish. The answer may therefore be not language, but literacy.

\section{ADEQUACY OF INFORMATION ABOUT VOUCHER SCHOOLS}

Did aware parents feel they had enough information to make informed program choices?

Aware parents were first asked:

Q40D. When it came time to make a choice, did you find you had enough information about the different programs being offered in the school you selected for your child(ren) or would you have liked to have more information about the program offered there?

About half the respondents said they had enough information (52 percent); 26 percent said that they would have liked more about the school they selected; and 23 percent simply could not say.

Parents responded to a similar question about schools not selected for their children: 
Q40E. What about the other schools in the voucher system-did you feel you had enough information about the different programs they were offering or would you have liked to have more information about the programs offered at the other schools?

Parents rated the adequacy of their information about other schools in about the same way they rated their information about the school they selected for their children; the correlation between these two ratings was 0.86 . Of the respondents, 43 percent were satisfied with the information they had about nonselected schools; 26 percent would have liked more information; and about a third had no feelings one way or the other.

There were no significant differences in ethnicity and education in aware parents' responses to the foregoing questions.

\section{INFORMATION DISTRIBUTION}

The Alum Rock school system was mainly responsible for distributing information about vouchers and explaining the voucher system to parents. That function is very important. On one hand, the actual effectiveness of this operation directly affects the operation of the voucher system by providing or failing to provide information vital to parents if they are to make rational program choices; and on the other hand, the perceived effectiveness of this operation by parents contributes to the overall community evaluation of vouchers.

Do parents think the school system has done a good job explaining the voucher system and its operation, and how accurate is their information?

The answer summarizes parents' perceptions of the school system's job performance in providing information. Parents were asked:

How good a job do you feel the school system has done in explaining the voucher system and how it works-do you think they have done a very good job, a good job, a fair job, or a poor job?

Of the respondents, 65.4 percent said the system had done a "good" or "very good" job. Whites were more satisfied than Mexican-Americans or blacks. Educational differences had no significant effect.

To probe in more detail parents' perceptions of the way Alum Rock provided information about vouchers, items were selectively asked of parents about personal agents of information distribution. Parents who employed teachers and principals (Q40E), parent counselors ( $\mathrm{Q} 40 \mathrm{~F})$, and friends (Q40G) as sources of information were asked to evaluate "how good a job they did in explaining the voucher system." Only 92 parents felt qualified to evaluate the effectiveness of teachers and principals in this respect, and only 90 felt qualified to evaluate parent counselors-less than 20 percent of the aware parents in each case. These selected parents thought very well of the two sources of information: over 80 percent believed teachers and principals did a good job, and over 70 percent believed that parent couselors did a good job. (So few parents (34) responded to the item on friends as a source that it was meaningless to analyze it.) 
In short, parents who felt qualified to pass judgment gave a positive evaluation to the information they received about vouchers and to its distribution. It is important to note, however, that most parents did not believe they were knowledgeable enough to make such judgments. One would have expected parents' knowledge about vouchers and their operations to increase during the school year.

\section{ACCURACY OF INFORMATION ABOUT VOUCHERS}

Aware parents generally believed they had enough information to make good choices among school programs, but this does not mean they actually did. To get an idea of the accuracy of their information, we asked parents who pays for school transportation for children in voucher programs (Q48), and we asked them if they agreed or disagreed with the following statement about the schools' transfer policy:

Q55B. Under the voucher system a parent can change the school his child attends at regular times during the school year.

About three parents in five knew that the school system provides free transportation as necessary for children attending voucher schools distant from their neighborhoods ( 58.7 percent) and only one parent in two knew that schools or programs can be changed at regular times during the year. There was a high level of "don't know" responses on the latter item (17.9 percent) among aware parents; this inflated the percentage of parents who had misinformation as opposed to no information. Thus, roughly one parent in two had correct information and one in six no information. At the time of the 1972 parent survey (November), however, transfer rules were still in flux, so it is difficult to interpret the responses to Q55B. 


\section{Appendix VII \\ DEMOGRAPHIC CHARACTERISTICS OF ALUM ROCK TEACHERS}

The following figures show demographic characteristics of Alum Rock's teachers by school.

\begin{tabular}{lcccccc}
\multicolumn{5}{c}{ Percent } & & Number of \\
Respondents
\end{tabular}

Fig. VII-1-Employment of teachers within Alum Rock, by age (fall 1972) 


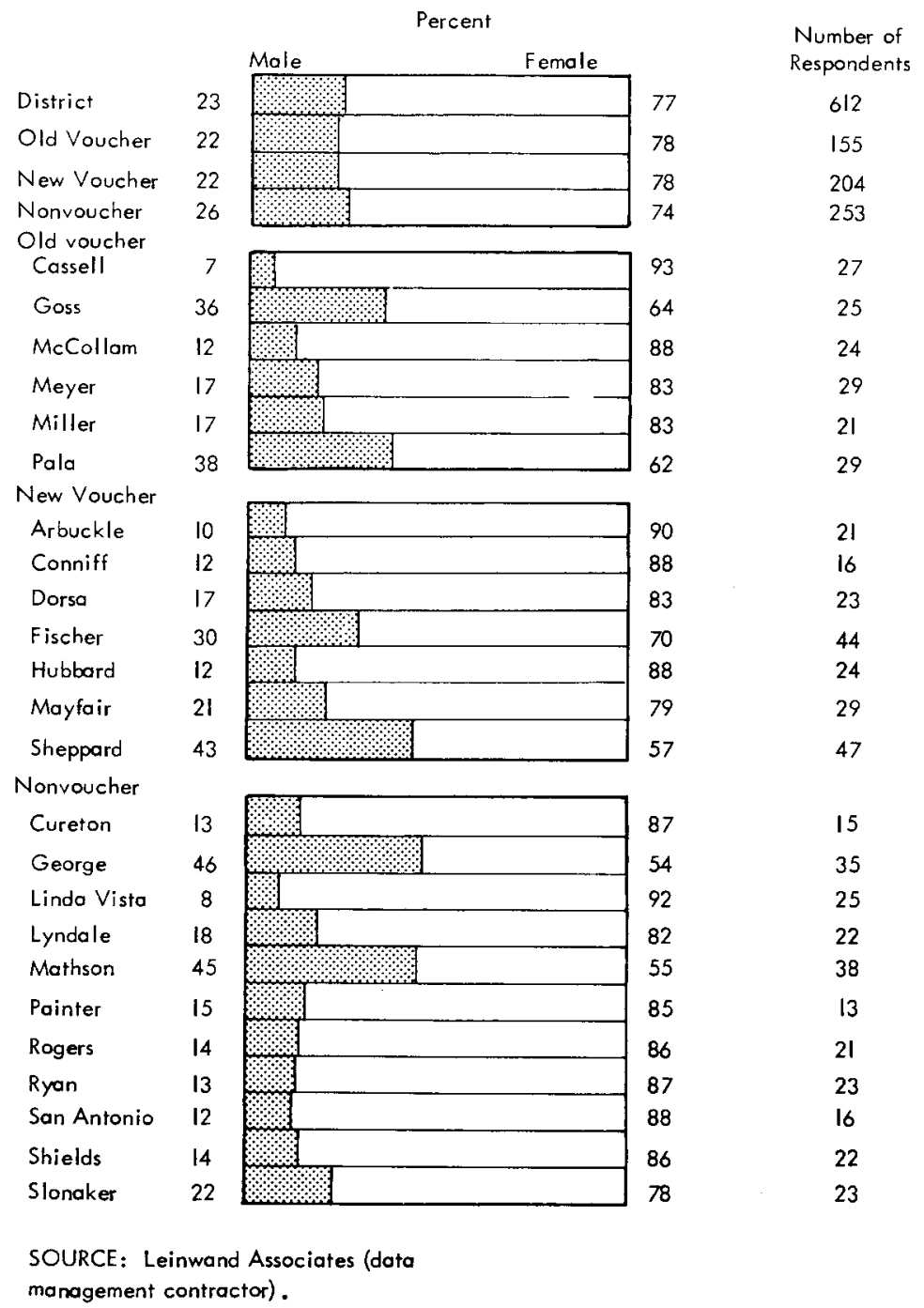

Fig. VII-2-Employment of teachers within Alum Rock, by sex (fall 1972) 


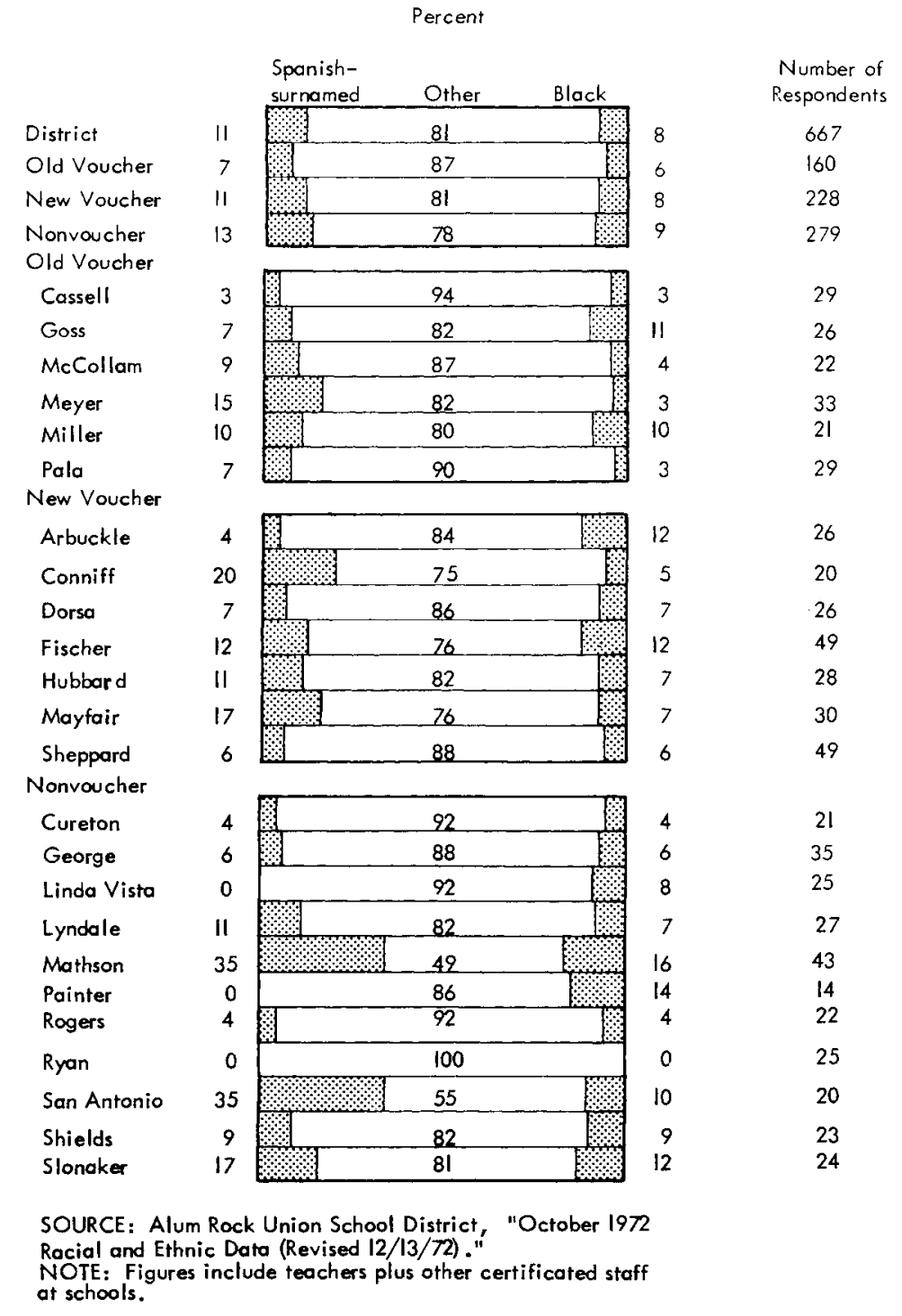

Fig. VII-3-Employment of Spanish-surnamed and black teachers within Alum Rock 


\begin{tabular}{|c|c|c|c|c|c|c|}
\hline & & & Percent & & & \\
\hline & & $\begin{array}{l}\text { Under } \\
\$ 11,000\end{array}$ & $\begin{array}{c}\$ 11,000- \\
13,999 \\
\end{array}$ & $\begin{array}{l}\$ 14,000 \\
\text { or more }\end{array}$ & & $\begin{array}{l}\text { Number of } \\
\text { Respondents }\end{array}$ \\
\hline District & 24 & & 45 & & 31 & 612 \\
\hline Old Voucher & 21 & & 51 & & 28 & 155 \\
\hline New Voucher & 25 & & 46 & & 29 & 204 \\
\hline Nonvoucher & 24 & & 40 & & 36 & 253 \\
\hline Old Voucher & & & & & & \\
\hline Cassell & 19 & & 48. & & 33 & 27 \\
\hline Goss & 32 & & 52 & & 16 & 25 \\
\hline McCollam & 25 & & 63 & & 12 & 24 \\
\hline Meyer & 24 & & 48 & & 28 & 29 \\
\hline Miller & 19 & & 57 & & 24 & 21 \\
\hline Pala & 10 & & 42 & & 48 & 29 \\
\hline $\begin{array}{l}\text { New Voucher } \\
\text { Arbuckle }\end{array}$ & 19 & & 57 & & 24 & $2 !$ \\
\hline Conniff & 19 & & 62 & & 19 & 16 \\
\hline Dorsa & 17 & & لمـ & & 22 & 23 \\
\hline Fischer & 30 & & 34 & & 36 & 44 \\
\hline Hubbard & 25 & & 50 & & 25 & 24 \\
\hline Mayfair & 38 & & 48 & & 14 & 29 \\
\hline Sheppord & 19 & 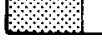 & 38 & & 43 & 47 \\
\hline Nonvoucher & & & & & & \\
\hline Cureton & 13 & & 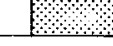 & & 60 & 15 \\
\hline George & 26 & & 40 & & 34 & 35 \\
\hline Linda Vista & 4 & & 13 & & 56 & 25 \\
\hline Lyndale & 18 & & 55 & & 27 & 22 \\
\hline Mathson & 47 & & 35 & & 18 & 38 \\
\hline Painter & 8 & 2 & & & 69 & 13 \\
\hline Rogers & 43 & & 24 & & 33 & 21 \\
\hline Ryan & 4 & 48 & 3 & & 48 & 23 \\
\hline Son Antonio & 12 & & 63. & & 25 & 16 \\
\hline Shields & 23 & & 41 & & 36 & 22 \\
\hline Slonaker & 39 & 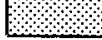 & 44 & & 17 & 23 \\
\hline
\end{tabular}

Fig. VII-4-Teachers' salaries in Alum Rock, by school (fall 1972) 


\title{
Appendix VIII-A
}

\section{METHODOLOGICAL ISSUES IN MEASURING STUDENT ACHIEVEMENT}

\author{
by Pierce Barker
}

\section{INTRODUCTION}

This section describes some of the problems associated with testing in a largescale social demonstration. It looks at the administrative and clerical problems of conducting the testing as well as at the problems of interpretation and comparability caused by out-of-grade-level testing, lack of control groups, and the high mobility of the student population. Because of the attendant problems, it is premature to draw any but the most tentative conclusions about achievement in the first year of the voucher demonstration. (Preliminary analyses of available data yield somewhat conflicting evidence about the performance of voucher students in the first year of the demonstration compared with other students and other years. However, the effects are small in magnitude, regardless of direction; i.e., they do not seem to have much practical significance. More definite conclusions must await further data and analyses.) Further analysis of the achievement data depends upon resolving the problems discussed in this section.

Measurement of student educational outcomes in the Alum Rock Voucher Demonstration comprises two components: achievement testing and affective measurement. As usually happens in educational evaluation, however, the emphasis is on achievement testing, although it must be remembered that in actuality achievement testing measures only one sector of a complex space in which students may be expected to change. Achievement tests do not measure certain dimensions of cognitive functioning (e.g., creativity) nor do they measure the complex area generally designated as affective. Measurement of both domains is difficult, although a few primitive instruments for measuring some dimensions of affect are available for elementary school children.

Rand arranged for the administration of the Metropolitan Achievement Test (MAT) to all students in the voucher demonstration schools in the fall of 1972 and spring of 1973. In addition, we administered various affective test batteries to samples of voucher students. Rand did no achievement or affective testing in nonvoucher schools. Our main purpose in evaluating the voucher demonstration through achievement testing is to chart the trend of test scores over time, both within Alum Rock and between Alum Rock and other reasonable comparison groups. On the basis of data gathered directly from the voucher evaluation, we are limited to charting trend lines from Year 1 as baseline to Year $\mathrm{n}$ within the district. Other comparisons depend upon data gathered and stored independently of the Rand study. For example, using test data from periods prior to the demonstration, we may be able to approximate a multiple time-series analysis. With test data on nonvoucher schools within the district, parallel trends can be examined; this would allow us to control to a large extent many between-district factors. Still other data may permit a comparison of voucher schools with other, similar districts.

Analyses or displays of this kind would at best seek to determine whether or not the voucher demonstration as a whole had a discernible effect on achievement 
scores; these effects would, of course, be at the district/demonstration level. There is also interest in internal analyses of, for example, the differential effects of programs or types of programs; given the exercise of suitable caution in drawing inferences, these comparisons may also be possible. In the same vein, given suitable sample size, we might in the long run examine more particular effects; for example, how did different programs or program types affect different types of students (e.g., students of different ethnic backgrounds or compensatory voucher students).

For the most part, the analysis of the first year's achievement data is aimed at resolving a number of testing issues that are seemingly endemic to demonstrations of this sort. What follows is a discussion of many of these issues, including tentative explorations of the adequacy of the data base. A definitive analysis of the effects of the demonstration as a whole, as well as more particular effects, depends upon the resolution of problems related to test administration and other issues to be discussed. Details of these and other analyses appear in Rand report R-1497-NIE, forthcoming.

\section{PROBLEMS OF ACHIEVEMENT TEST ADMINISTRATION}

\section{Testing at Achievement Level}

On the whole, students in Alum Rock do not achieve at grade level; for example, many students enrolled in the 5th grade might well be able to read on a level expected of the modal or "average" student in the 3rd grade. Looking at the matter the other way around, it might easily happen that 4 th grade students were reading over a range of, say, 1st to 6th grade, with comparatively few at or above the 4th grade level.

In testing situations, then, an important question is, "What level of test shall students be asked to take?" If a 4th grade student can read only at the 1st or 2nd grade level, most of the student's answers to a 4th grade reading test are likely to be guesses; and if this is true, the score probably has no meaning. But perhaps the student is tested on a level appropriate to the student's achievement level, whatever it may be, without regard to nominal grade level. This means that each grade may have a wide range of achievement levels among its students, and therefore a wide range of tests should be offered within a grade.

Evaluation of educational programs, however, is generally concerned with the impact of programs on groups of students, so that evaluators are mainly interested in summary statistics, e.g., means, medians, and measures of variability. These statistics, of course, depend for meaning in some sense on the assumption that they summarize numbers that are the "same thing." More concretely, it is not obvious what an average score means if it is based on scores from, say, four or five different tests, even though they may all be testing "reading."

The MAT was selected for use in the voucher demonstration for a number of reasons. The University of California at Los Angeles Center for the Study of Evaluation has published a comparison of the usefulness of various available achievement tests in the elementary grades. ${ }^{1}$ In terms of measurement validity, examinee appropriateness, administrative usability, and excellence of technical norms, the MAT was rated consistently higher than all other tests, and was also recommended by

\footnotetext{
${ }^{1}$ R. Hoepfner (ed.), CSE Elementary School Test Evaluation, Center for Study of Evaluation, UCLA Graduate School of Education, Los Angeles, 1970.
} 
several authorities in the educational field. In addition, the MAT is mandatory in the Title I program, and comparisons are thus possible between voucher and Title I schools. Finally, and not least important, the Alum Rock school personnel generally accepted the MAT.

Teachers in Alum Rock were insistent that giving each student a grade-appropriate test would be useless if not harmful in a great many cases. Many teachers had been working hard to give students material tailored to their own achievement level, in an effort to provide them with success experiences. Since the achievement tests were not administered until early November, teachers were especially reluctant to risk undoing this work by exposing students to a failure situation. The result was that a great deal of out-of-grade testing was done, and it remains to be determined whether the scores can in fact be compared meaningfully.

The publishers of the MAT anticipated the problem of out-of-grade testing by providing a transformation of raw scores, which theoretically enables a user to place the score from any collection of subtests in the same area on a common linear scale. However, this was a theoretical exercise; and it also is not clear how appropriate the scoring system is for a group of largely educationally disadvantaged students who are taking an unusually wide range of tests.

One partial solution is to attempt to verify the validity of the published transformations for Alum Rock students. Accordingly, a small study was done on all 3rd grade students in Alum Rock to determine for two adjacent test levels whether or not the transformations seemed to work. The results are complex, but it seems tentatively reasonable to say that the transformations seem valid, with a not enormous margin of error. But additional work is needed to determine whether this result will hold over wider ranges of test levels.

\section{Administrative Problems}

Some administrative difficulties developed during each testing session. For example, in the fall of 1972 teachers had to record the students' names, ID numbers, and ethnicity on the answer sheets and booklets before the test was administered. As this procedure appeared to absorb a great deal of the teachers' time and many teachers were already commenting on the many extra burdens imposed on them by the voucher demonstration, Rand decided to procure clerical assistance to perform these tasks in the spring. Thus, for the spring administration, these data were entered on each student's answer sheet and test booklet before these materials were delivered to the schools. Another problem that developed during the spring testing involved the actual test booklets-a number of the MAT booklets had missing or upside-down pages. The manufacturer was informed of this problem, but the teachers were nevertheless inconvenienced and the testing process was disrupted.

Three test coordinators were hired for spring testing to provide any assistance the teachers might need. Each coordinator was assigned to work closely with two voucher schools. The coordinators initially contacted the school principals and scheduled meetings with each mini-school faculty or a faculty representative to discuss test procedures, scheduling, or any problems that the teachers felt might arise. Before testing sessions began, the coordinators delivered the test materials to the schools; when testing was completed, they picked the materials up and returned them to the Rand office to be sorted, packaged, and mailed to the scoring service. Although the coordinators spent a great deal of time in the schools, they did not formally observe the testing conditions or procedures used. Thus, although their presence may have lessened the burden on the teachers, it is likely that they had no impact on the actual testing conditions or procedures that the teachers followed. 
One difficulty that teachers faced in administering the achievement tests involved the multilevel testing within a classroom. Although there were no official Rand observers to monitor the testing during either the fall or spring administrations, teachers have mentioned during conversations with Rand staff members that they attempted to solve this problem by switching portions of their classes with other teachers who were testing at the same grade level, so that each teacher would only be required to administer one level at a time.

Test scoring was accomplished in a series of steps during both the fall and spring. When the completed test booklets and answer sheets had been returned to the Rand

San Jose office, staff members sorted the test sheets, then scored those portions of the tests that required handscoring. The levels involved were the spelling and/or math subtests of the Primer, Primary I or II, and Elementary test levels. The tests were then packaged and sent to National Computer Systems (NCS) in Minneapolis, Minnesota, for machine scoring and processing.

Some problems associated with the scoring process for the fall test administration should be noted. Although the tests were delivered to NCS early in December, the results were not returned until mid-February because NCS received a great deal of business at this time and was not prepared to handle such a large volume at once; in addition, although the MAT test handbooks state that any test level may be given to any student, the conversion tables (raw score to standard score and grade equivalent) that NCS used were not adequate to handle the type of out-of-level testing done in Alum Rock. Some additional programming was required to process the tests. Although NCS did send the results to Rand in mid-February, NCS later notified Rand that due to a programming error, all total reading scores for Primary I and Primary II levels for the fall tests were reported from three to ten months lower than actual scores. NCS created a new tape with the correct data and sent it to Rand during the summer.

The scoring problems proved irritating to the teachers, as many had hoped to be able to use the test results to identify. areas where students needed help. Since the results arrived so late in the school year, they were probably unable to fulfill this expectation. Rand staff members held a meeting with representatives of each minischool faculty in mid-February to explain the test results and the reasons for the delay.

In general, the fall testing encountered more problems than the spring test sessions. Many of the changes implemented in the spring were oriented toward smoothing out previous areas of difficulty. NCS appeared to improve its service considerably for the spring round of testing (apparently some of its earlier problems had also been eliminated). Work was carried on over the summer at Rand to try to further reduce testing problems-e.g., the development of the achievement placement test described below. In addition to improving the quality of the data, it would give teachers more opportunity to plan cooperatively when administering several levels of an achievement test.

\section{DEVELOPING AN ACHIEVEMENT PLACEMENT TEST}

In response to problems encountered in 1972-73, Rand developed a short placement test to aid teachers in selecting the appropriate test level for each student for the fall 1973 test administration.

One may think of the process of assignment of students to test levels by teachers' informal judgments as the use of a kind of relatively unstandardized, implicit placement test. That is, one uses as an assignment criterion prior data on the students 
which is processed in unstated and probably idiosyncratic ways to produce an implicit function predicting student performance. ${ }^{2}$

It is easy to imagine a number of difficulties with this process. Perhaps the most formidable, from our perspective, is that this implicit pretesting process is not explicitly linked to the achievement battery we are using. Now, any achievement test is necessarily based upon a sample (however derived) of items thought by the test writer to represent, optimally or reasonably, achievement in a particular area; and this sample will not be the sample chosen by another tester: the correlation between two grade $(\mathrm{k})$ tests of, say, reading, is not 1.00. For any specific achievement test, however, samples of items on parallel forms are more likely to be drawn from a more closely defined item universe than are items said to measure achievement in the same area that are sampled (constructed) by another tester. Presumably, then, performance on one form of a given test is likely to be a better predictor of performance on another form of the same test than is anything else at hand. Now, what we mean by "achievement" in the present context is just a student's score on a particular testing form. It seems to follow that the more explicit we can make the placement process and the closer we can link it to the achievement battery in use, the better our placement procedure is likely to be, where "better" means assigning students to proper test levels.

With this preface, we can begin to explore what we may call the theory of the placement test. The trouble with the usual achievement test is that each test level measures only within a fairly narrow range; and one gets only one guess at what the proper range for a given student should be. It is as if one had a set of scales, each of which would record accurately only for a limited range of weights; and, in order to know which scale to pick to get an accurate weighing for an individual, one had to know before weighing approximately how heavy the individual was. To continue the analogy, one requires another scale, which weighs perhaps more crudely but over a wider range; and the crudeness of the preliminary scale is not really much of a drawback, since having used it, one should have a much improved chance of placing the individual on the proper, more accurate scale among the set of accurate scales. The present problem is to find or create an achievement test that will function much like the crude scale of the analogy: it will cover a wider range of ability; it will presumably not give as accurate a reading of the student's achievement as will the proper more sensitive test, but (if properly constructed) it should give an accurate indication of which more sensitive test to give. So how do we achieve this cruder but broader range test? As a first approximation, the best available answer seemed to be the following:

1. Choose one of the parallel forms of the MAT that would not be used in actual testing.

2. Pick from among the available subtests one which

(a) Was as robustly correlated with other subtests across all test levels as possible.

(b) Had a relatively constant format across all test levels.

(c) Was prima facie unifactorial in structure, such that items could be sampled with relative ease without concern for differing content or required skills.

3. Choose from the items on this subtest a sample from each necessary test level such that the sample would be representative of the subtest at that level.

4. Form from these samples a new subtest by, as it were, laying the samples from test levels of increasing difficulty end to end, so that the new subtest would in

${ }^{2}$ P. E. Meehl, Clinical vs. Statistical Prediction, University of Minnesota Press, Minneapolis, 1954. 
fact cover a wider ability range than any of the proper subtests taken individually, but would do so more crudely than any individual proper subtest ifthe proper subtest were at the proper level for the student.

Upon considering the various subtests, we concluded that Word Knowledge (WK $=$ vocabulary) fulfilled the above requirements better than the others. That is, the correlation of WK with other subtests has a median higher than that of any other subtest across all levels; its format is as nearly uniform across levels as possible; and it is prima facie a one-factor test. In short, from subtests available, WK looked more likely to work than any other. The question remained, would anything work? Theoretically, the answer is, "Sure it will!" In fact, there is at least one relevant (if somewhat oblique) precedent for this procedure in the individual (as opposed to group) testing area. ${ }^{3}$ Before administering the Stanford-Binet, the tester gives the subject a wide-range oral vocabulary test to determine a rough floor and ceiling for the subject, thereby establishing a useful testing range. That, of course, is just what we are trying to do for group testing.

However, the present effort is very much a theoretical exercise; that is, we must make a number of assumptions that may lack empirical support in the population at hand. Put another way, the field trial and the application of the instrument are identical: the pretest of the instrument, which in the normal course would provide data only to check the instrument itself, was also its first real-world application.

Analysis of fall 1973 testing is in process, and it is too early to say whether the placement test in fact improved the proportion of useful scores, i.e., those that give the most accurate reading of a student's achievement.

\section{PROBLEMS OF COMPARABILITY AND INTERPRETATION}

\section{Problems of Group and Data Comparability}

In the absence of formal comparison groups, comparisons for the voucher demonstration depend upon the definition of comparable groups, i.e., groups as similar as possible to the group composing the voucher schools. One such group might reasonably be nonvoucher Alum Rock schools. These schools will, of course, be similar in many ways to voucher schools, more similar perhaps than most others, but they do differ in that they did not elect to become voucher schools. This may or may not have a bearing upon academic achievement measures, but the question cannot be decided by fiat. A partial solution to this difficulty lies in what has been called the multiple time-series mode of analysis, which essentially charts trends for nonrandomized groups over periods of time sufficient to extend reasonably well on both sides of some arbitrary point of intervention. ${ }^{4}$

Even if these groups were sufficiently comparable, the problem remains of finding comparable data. For example, most or all of the schools in Alum Rock do achievement testing; some of this is done by Rand for evaluating the voucher demonstration, some by the district in response to requirements of various state aid programs, some in response to statewide school evaluation programs. However, these testing programs do not generally use the same tests. The problem, then, is to

translate raw scores on one test into those of another. For example, we might want

\footnotetext{
${ }^{3}$ Robert Rosenthal, personal communication.

${ }^{4}$ D. T. Campbell and J. C. Stanely, Experimental and Quasi-Experimental Designs for Research, Rand-McNally, Chicago, 1963.
} 
to compare voucher with nonvoucher 6 th grades over time, even though the voucher schools were tested part of the time with the MAT and previously with the California Test of Basic Skills (CTBS), and the nonvoucher schools are currently tested with CTBS and formerly in some cases with the Stanford Achievement test (SAT). Comparability studies have been done, sometimes by the test publishers, sometimes by outside researchers such as Educational Testing Service (ETS), to attempt to equate scores on one subtest with those on a different but comparable subtest.

As it happens, there are commonalities over groups in available data. For example, all schools in Alum Rock test their first, second, third, and sixth grade students with tests mandated by the State of California, so that comparisons between, say, voucher and nonvoucher Alum Rock schools for these grades may be done over time. Also, in 1972-73 Title I schools in Alum Rock, which are not in the voucher demonstration, tested their students with the MAT, and starting in 1973-74 MAT was extended to all nonvoucher schools; so that these schools may be compared on MAT with voucher schools. The problem of divergent results appearing dependent upon which test scores are used is quite thorny, as appears in preliminary analyses elsewhere in this report. Still, these problems should not be insuperable, and extensive analyses of data sets of this type are contemplated; some results of such analyses will appear in Rand report R-1497-NIE, forthcoming.

\section{RELIABILITY OF TESTS IN ALUM ROCK}

Although test publishers commonly investigate the reliability of their achievement tests before releasing them for public use, it is a matter of prudence, and recommended by many publishers, to determine reliability under actual conditions of use. After defining a population of Alum Rock students as comparable as possible to the population used by the test publisher, we investigated the reliability of all subtests at all levels for both the spring and fall testing periods. For various reasons, we did not expect reliabilities to be as high for any local, fairly homogeneous population as they are for a national sample of students. Allowing for this, however, most subtests on the basis of use in Alum Rock seem to be sufficiently reliable for evaluation purposes.

\section{SOME PROBLEMS WITH COMPARING STUDENTS OVER TIME}

Any generalizations we might hope to make about the voucher demonstration would ideally apply to "the students in Alum Rock schools," where this is understood to refer to the whole population of students now in school and other students like them.

Suppose we wanted to study test score trends over a period of, say, three years, by following the same students and testing them at regular intervals. We might do this, for example, by choosing a random or stratified random sample of students and actually testing them, say, twice yearly for three years. (This would depend upon our ability to follow these same students over time, which would imply among other things that the students stayed in Alum Rock and stayed in the voucher demonstration.)

From the test data we have for this year, our best estimate is that the mobility of Alum Rock students is about 30 percent annually, which amounts to about 51 
percent over two years. This is consistent with available estimates from Alum Rock. ${ }^{5}$ If we had a large enough sample to start with, the percentage leaving would not matter because there would be enough students sufficiently well distributed over classes of interest, as long as the students who left did not differ significantly on relevant characteristics from those who remained.

Among relevant characteristics are such things as race and class indicators; but, other things equal, one expects students of lower socioeconomic status (SES) to be more mobile, i.e., that the more mobile students will differ in relevant ways from those who remain over a period of years.

To determine whether this seemed likely to be true in Alum Rock, we investigated the differences between students who were present in the Alum Rock voucher schools long enough to be tested in the fall and spring, those who left after the fall testing, and those who arrived after the fall testing.

The results are complex and equivocal, and not easily summarized; full details appear in the report previously mentioned. Briefly, however, it can be said that differences appear in pre- and post-test scores that may or may not be sufficiently important to cast doubt upon comparisons and generalizations. Differences in proportions of ethnic groups seem small, while differences in economic or class indicators are larger and quite possibly significant.

\section{PROBLEMS IN ASSESSING INTERNAL EFFECTS}

In looking for "effects" of the voucher demonstration on academic achievement, we might take at least two approaches. First, we could compare students in voucher schools with other students. But this is a very gross procedure; after all, the voucher demonstration as it has evolved is not, so to speak, a single treatment, nor are all the students alike. A number of variations within the demonstration might be expected to have different effects, or even different effects for different kinds of students.

The most obvious problem associated with this way of looking at the matter arises when we try to look at gross classifications of students in isolation; for example, we might want to look at white students versus others. This may, in fact, be a fairly reasonable thing to do; for white and other students are both fairly well distributed over the various classifications into which we might sort students-say, grades, mini-schools, SES, and so on.

If we took our second approach and wished to look at the effects of types of mini-schools in isolation, the problem would immediately become much more complex. Basically, this results from what is technically called "confounding." Suppose one wished to test the efficacy of male as against female teachers in using a given teaching method, and one chose one male and one female teacher to use the method and assessed the results. The problem is already there, but to make it more obvious, suppose the male teacher were white and the female black. Suppose also that the results for the first teacher were clearly worse than those for the second, and we wanted to conclude that female teachers were better. Someone could reasonably ask how we knew that the difference was not in fact the result of a racial rather than

\footnotetext{
${ }^{5}$ Report to the Trustees of Alum Rock Union Elementary School District, 1972. This report on achievement testing noted a 30-percent loss between 1st and 2nd grades of students tested as 1st graders, and a 50-percent loss between 1st and 3rd grades of students tested as 1st graders, implying an annual loss rate of 30 percent from the initial cohort.
} 
a sex difference, i.e., that we had shown that black teachers were better than white with this method.

Of course, the answer is that we would not know, nor could we on the basis of a study so conducted, because sex and race would be completely confounded. Something like this is to be found in the voucher demonstration; certain types of programs probably attract certain kinds of students, and it would not be simple to say whether differences were due to programs or students. Programs are not evenly distributed across schools, so that it would also be difficult to separate program effects from school effects.

This is not to say that the problem is hopeless; only that it is difficult and demands very careful handling to avoid erroneous inferences.

\section{SUMMARY}

As the problems described above indicate, we are still far short of the ideal we may implicitly have in mind when we consider assessment of student achievement.

Whatever the school system involved, it is never a wise idea to try to assess the effects of schooling simply by subtracting spring scores from fall scores and looking at the difference. However, given this, in what we might think of as the "average" school system, we might expect problems connected with the assessment to be manageable.

In Alum Rock, it quickly became obvious that the problem of assessing achievement is qualitatively different from that encountered in many school districts. The variety of educational offerings is probably wider in Alum Rock voucher schools than in most school districts in the country. The span of achievement within single grades and indeed classrooms is unusually wide, and this leads to severe problems in interpreting test scores. The mobility rate among a subset of students is high, which makes for problems in assessing the progress of students over time and generalizing the results of any analyses to the voucher schools as a whole.

This is not to say that meaningful assessment of student achievement in Alum Rock is impossible; but efforts at assessment, prior to careful examination of the data base and painstaking efforts to resolve the problems with that data base, would be premature and in many cases quite misleading.

Finally, it does not seem prudent to try to draw more than very tentative conclusions from first-year data. This would be true in any case, simply because more than two time points are in general required for assessing trends; but the presence of unusual problems must reinforce the need for caution in assessing achievement. 


\title{
Appendix VIII-B
}

\section{PRELIMINARY ANALYSIS OF ACHIEVEMENT TEST SCORES IN ALUM ROCK VOUCHER AND NONVOUCHER SCHOOLS, 1972-73}

\author{
by Robert E. Klitgaard ${ }^{1}$
}

\section{AN INTERESTING BUT LIMITED QUESTION}

One part, but only one, of an analysis of an educational program concerns students' achievement scores. Although some educators have correctly criticized achievement tests as partial and inexact measures of success, there is still a place for the assessment of educational programs using test scores. Parents, educators, and the public are interested in knowing whether average test scores have gone up or down; whether there is more or less equality among students; whether the scores of certain socioeconomic and ethnic groups have risen or fallen; and whether more or fewer students have surpassed some threshold of basic skills. So long as one recognizes that test scores are not the whole story, and are imprecise even in measuring cognitive skills, the use of achievement tests to analyze program success is of interest and importance.

The Education Voucher Demonstration in Alum Rock is not one but many educational programs. Within the six schools participating in the first year, 22 mini-schools were initiated, differing in curricula, pedagogical methods, classroom organization, and educational objectives. A thorough analysis of the demonstration's effect on student achievement would differentiate among the various programs and would examine the many effects on scores that programs might have (for example, those mentioned in the preceding paragraph). ${ }^{2}$ This appendix, however, investigates only a single broad question: Did voucher programs as a whole tend to raise or lower the average achievement score in a grade?

There are two reasons for limiting the scope of this investigation so severely. First, because data on test scores are available only for the first year of the demonstration, only the broadest trends can be gauged; and even then there is no assurance that those trends will persist. "Learning curves" or "Hawthorne effects" could be invoked to explain away either drops or gains.) Second, intraschool information is not currently available; as a result, the effects of different mini-schools within the same school and grade cannot be disentangled at present.

Given these factors, this appendix is confined to comparisons of the average test scores of the six voucher schools (for grades 1,2,3, and 6) with previous scores from those schools, with scores from nonvoucher schools in Alum Rock, and with the scores predicted by time trends and socioeconomic variables.

\section{THE DATA}

Every spring, California tests its first, second, and third graders and gathers

${ }^{1}$ I am grateful to Kathleen Styles for research assistance.

${ }^{2}$ See R. E. Klitgaard, Achievement Scores and Educational Objectives, The Rand Corporation, R-1217NIE, January 1974. 
information about the number of students in each public school whose families are on welfare (Aid to Families with Dependent Children). Every fall, the state tests its sixth and twelfth graders and gathers data on the ethnic composition of each school and about the number of students eligible for free school lunches. Unfortunately (from the analyst's point of view) California has not been uniform over time in the type of tests given, and did not collect AFDC and free lunch information before 1970-71. Table VIII-B.1 summarizes the data available from the state government.

Table VIII-B.I

TEST AND SOCIOECONOMIC DATA AVAILABLE FROM THE STATE OF CALIFORNIA

\begin{tabular}{|c|c|c|c|c|c|}
\hline Item & $1969-70$ & $1970-71$ & $1971-? 2$ & $1972-73$ & $1973-74$ \\
\hline $\begin{array}{c}\text { First grade tests } \\
\text { Cooperative Primary } \\
\text { Reading Test } \\
\text { State Reading Test }\end{array}$ & $\mathrm{X}$ & $x$ & $X$ & $X$ & (a) \\
\hline $\begin{array}{l}\text { Second grade tests } \\
\text { Stanford Reading Test } \\
\text { Cooperative Primary } \\
\text { Reading Test } \\
\text { State Reading Test }\end{array}$ & $x$ & $x$ & $X$ & $\mathrm{X}$ & (a) \\
\hline $\begin{array}{l}\text { Thlid grade tests } \\
\text { Stanford Reading Test } \\
\text { Cooperative Primary } \\
\text { Reading Test } \\
\text { State Reading Test }\end{array}$ & $X$ & $X$ & $x$ & $X$ & (a) \\
\hline $\begin{array}{l}\text { Sixth grade tests } \\
\text { Comprehensive Test of } \\
\text { Basic Sk111s } \\
\text { Lorge-Thorndike } \\
\text { Intelligence Test }\end{array}$ & $\mathrm{X}$ & $\begin{array}{l}\mathrm{X} \\
\mathrm{X}\end{array}$ & $\begin{array}{l}\mathrm{X} \\
\mathrm{x}\end{array}$ & $\mathrm{X}$ & $\begin{array}{l}\mathrm{X} \\
\text { no }\end{array}$ \\
\hline $\begin{array}{l}\text { Socioeconomic status } \\
\text { (by school) } \\
\% \text { Mexican-American } \\
\% \text { black } \\
\% \text { welfare } \\
\% \text { free lunch }\end{array}$ & $\begin{array}{r}X \\
X \\
\text { no } \\
\text { no }\end{array}$ & $\begin{array}{l}X \\
X \\
X \\
X\end{array}$ & $\begin{array}{l}X \\
X \\
X \\
X\end{array}$ & $\begin{array}{l}\mathrm{X} \\
\mathrm{X} \\
\mathrm{X} \\
\mathrm{X}\end{array}$ & $\begin{array}{l}X \\
X \\
(a) \\
X\end{array}$ \\
\hline
\end{tabular}

$a_{\text {Not yet processed. }}$

Two comments are in order. First, note the limited socioeconomic information that is obtained. It includes only the broadest proxies for the socioeconomic backgrounds of a school's students; it is available by school but not by grade or by student; and it is not uniform over time. Stem-and-leaf diagrams comparing the percentages of students in each school eligible for free lunches over the past three years show a strong shift upwards, leading one to believe that the definition of eligibility was changed: 


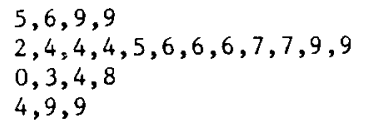

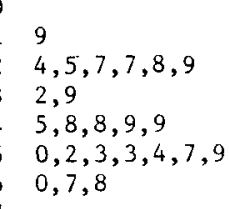

$1971-72$
$3,8,9$

$3,4,5$

1,8

5,9

$0,2,4,5,6,6,9,9$

$0,0,0,3,5,8$

$1972-73$

(Numbers to the left of the vertical line are in units of ten; to the right in units of one; thus, beginning in 1970-71, one reads: " $5,6,9,9,12,14,14,14$ " and so forth. ${ }^{3}$ ) Also, the Lorge-Thorndike intelligence test was not given in Alum Rock in 1973-74. Second, since different tests were used in second and third grades, raw scores for different years are difficult to compare; and it is hard to compare raw scores across grades. To overcome these problems, scores were converted into percentile scores, based on the distribution of California student scores in each grade and year, and then they were transformed into standard normal scores with a mean of 0 and a standard deviation of 1 .

The spread of scores among students is of course wider than the spread of school or district mean scores. Thus, for example, if a school had an average raw score of 20 on the first grade Cooperative Primary Reading Test, this corresponded to the 16th percentile among school averages, but the 31st percentile in interstudent terms. The interstudent percentile was chosen as the form of reexpression because it was available over all years and grades.

In transforming scores into standard normal scores the 20th percentile, for example, is a standard normal score of -0.842 , the 50 th percentile a score of 0 , and the 90th percentile a score of 1.282 . Percentile scores are difficult to work with statistically because a five-point increase signifies a much greater increase when it occurs in the tails than it does around the mean. Using the standard normal score overcomes this problem.

\section{PERFORMANCE OF VOUCHER SCHOOLS BEFORE AND AFTER}

Table VIII-B.2 displays the 1971-72 reading scores of voucher schools with those a year later, after the voucher demonstration had begun. For the sixth grade, the 1973-74 scores are also shown.

In the first, second, and third grades, 14 of the 15 scores showed drops. (The only gainer was Cassell in the first grade, a rise of 0.6 points.) A Wilcoxon signed rank test indicated that the difference between the two years was statistically significant at the 0.062 level for the first grade and the 0.031 level for second and third. The average loss was 2.3 points in the first grade, 3.3 in the second grade, and 1.6 in the third. (A Wilcoxon signed rank test was used for several reasons. It would not be wise to assume that the two years' scores represent independent samplings from normal distributions, because the distribution across voucher schools of each year's scores is not normal-looking, or even symmetrical. Also, the sample size is very small. As

${ }^{3}$ See John W. Tukey, Exploratory Data Analysis, limited preliminary ed., Addison-Wesley, Reading, Mass., 1970. 
Table VIII-B. 2

RAW READING SCORES IN VOUCHER SCHOOLS

\begin{tabular}{|c|c|c|c|c|c|c|c|c|c|}
\hline \multirow[b]{2}{*}{ School } & \multicolumn{2}{|c|}{ First Grade } & \multicolumn{2}{|c|}{ Second Grade } & \multicolumn{2}{|c|}{ Third Grade } & \multicolumn{3}{|c|}{ Sixth Grade } \\
\hline & $1971-72$ & $1972-73$ & $1971-72$ & $1972-73$ & $1971-72$ & $1972-73$ & $1571-72$ & $1972-73$ & $1973-74$ \\
\hline $\begin{array}{l}\text { Cassell } \\
\text { Goss } \\
\text { McCollam } \\
\text { Meyer } \\
\text { Miller } \\
\text { Pala } \\
\text { Dorsab } \\
\text { Fischer } \\
\text { Sheppard }\end{array}$ & $\begin{array}{l}18.0 \\
24.3 \\
20.6 \\
27.2 \\
24.7\end{array}$ & $\begin{array}{l}18.7 \\
20.5 \\
19.5 \\
24.4 \\
20.5\end{array}$ & $\begin{array}{l}20.8 \\
30.1 \\
24.5 \\
25.2 \\
25.6\end{array}$ & $\begin{array}{l}19.7 \\
22.3 \\
21.7 \\
24.5 \\
21.4\end{array}$ & $\begin{array}{l}28.9 \\
32.4 \\
34.8 \\
31.5 \\
27.9\end{array}$ & $\begin{array}{l}28.3 \\
29.1 \\
31.6 \\
31.0 \\
27.6\end{array}$ & $\begin{array}{r}\text { (a) } \\
43.6 \\
(a) \\
(a) \\
42.2 \\
52.3 \\
(a) \\
43.9 \\
44.9\end{array}$ & $\begin{array}{r}42.9 \\
40.2 \\
(a) \\
44.2 \\
38.5 \\
50.5 \\
(a) \\
44.7 \\
41.8\end{array}$ & $\begin{array}{r}42.5 \\
41.3 \\
(a) \\
39.2 \\
39.9 \\
47.4 \\
36.0 \\
42.8 \\
43.3\end{array}$ \\
\hline
\end{tabular}

${ }^{\text {No }}$ sixth grade in that year.

${ }^{b}$ Nonvoucher school in 1972-73, but became a voucher school in 1973-74.

a result, a t-test seems unwise. The Wilcoxon test enables us to take advantage of the matched pairs of observations, without assuming normality and without giving "undue" weight to "outliers." For the first grade, the Wilcoxon statistic W $=13$; for the second and third, $\mathrm{W}=15$; the probability that $\mathrm{W}$ would be that large by chance is, respectively, 0.062 and 0.031 .)

The sixth grade scores are more difficult to interpret. The fall 1972-73 tests were given after only two months of the voucher demonstration; it would be difficult to assess a program after such a short time. The three schools for which comparisons with the previous year can be made all had lower scores, averaging 3.0 points less. If, instead, one compares the fall 1973-74 results with the scores in the same schools two years earlier, once again all schools have shown losses, the average drop being 2.4 points $(\mathrm{P}=0.031)$.

Perhaps, however, 1971-72 was simply a very good year for the voucher schools and the lower 1972-73 scores are a return to previous levels; or perhaps the losses observed over that one-year span are part of a longer-term trend of lower scores. In either case the voucher demonstration could not be blamed for the drop. To test these hypotheses, Table VIII-B.3 compares the first year of vouchers with the three previous years, giving the mean standard normal score of all voucher schools in each cell. (A similar table using trimeans instead of means as the summary statistic in each cell yielded qualitatively equivalent results.)

Table VIII-B.3

COMPARISON OF NORMALIZED SCORES

OVER TIME IN VOUCHER SCHOOLS

\begin{tabular}{l|c|c|c|c}
\hline \multirow{2}{*}{ Year } & \multicolumn{4}{|c}{ Grade } \\
\cline { 2 - 5 } & 1 & 2 & 3 & 6 \\
\hline $1969-70$ & -0.50 & -0.37 & -0.61 & -0.57 \\
$1970-71$ & -0.24 & -0.23 & -0.53 & -0.69 \\
$1971-72$ & -0.15 & -0.25 & -0.60 & -0.58 \\
$1972-73$ & -0.42 & -0.62 & -0.77 & -0.71 \\
$1973-74$ & & & & -0.77 \\
\hline
\end{tabular}


Except for the first grade, scores were lower in each grade during the first year of the voucher demonstration than in any of the previous years. (The 1969-70 first grade mean was 0.08 of a standard deviation lower than the 1972-73 average score.) There is no significant trend over time in any grade. One does see substantial variation in the scores, however. How large are the losses in 1972-73 in terms of this variation?

Table VIII-B.4 shows the results of a two-way analysis of variance of the data in Table VIII-B.3. (The 1973-74 score has been inserted for the sixth grade in place of the 1972-73 score. State percentiles have not yet been published, so I used the 1972-73 percentiles to transform the 1973-74 score. Percentiles do not change much from year to year, so this adjustment should cause virtually no inaccuracy.) The

Table VIII-B. 4

TWO-WAY ANALYSIS OF VARIANCE, VOUCHER SCHOOLS, 1969-70 TO 1972-73

\begin{tabular}{|c|c|c|c|c|c|}
\hline \multirow[b]{2}{*}{ Year } & \multicolumn{4}{|c|}{ Grade } & \multirow[b]{2}{*}{ Row Effects } \\
\hline & 1 & 2 & 3 & 6 & \\
\hline $1969-70$ & -0.15 & 0.02 & 0.04 & 0.10 & -0.02 \\
\hline $1970-71$ & 0.02 & 0.07 & 0.03 & -0.11 & 0.07 \\
\hline $1971-72$ & 0.08 & 0.02 & -0.07 & -0.03 & 0.10 \\
\hline $1972-73$ & 0.06 & -0.10 & 0.01 & 0.03 & $-0.15^{a}$ \\
\hline Column effects & 0.17 & 0.13 & -0.13 & -0.16 & -0.49 Grand mean \\
\hline
\end{tabular}

\footnotetext{
${ }^{a}$ Sixth grade score for $1972-73$ is actually the score from
} the fall 1973 testing.

1972-73 "row effect" is -0.15 of an interstudent standard deviation and is larger than the effect of any other year ("row"). The row effects are significantly different from zero $(P=0.03)$. These results were reinforced by an analysis of the same table using resistant "two-way" techniques developed by Tukey. ${ }^{4}$ The best guess of the effect of the voucher program year, given the performance of the voucher schools in previous years, is a drop of about one-sixth of an interstudent standard deviation on reading scores. A two-way midmean analysis of the data of Table VIII-B.3 yielded the following:

$\begin{array}{lrcrcc} & 1 & 2 & 3 & 6 & \text { Row Effects } \\ 1969-70 & -0.25 & -0.04 & -0.01 & 0.05 & 0.01 \\ 1970-71 & -0.05 & 0.03 & 0.01 & -0.14 & 0.07 \\ 1971-72 & 0.03 & 0.00 & -0.07 & -0.04 & 0.08 \\ 1972-73 & 0.00 & -0.13 & 0.00 & 0.02 & -0.16 \\ \text { Column effects } & 0.20 & 0.12 & -0.15 & -0.17 & -0.46\end{array}$

\footnotetext{
${ }^{4}$ Ibid.
} 
The cell residuals $R_{i j}$ were regressed against their expected values (the product of the column effect $i$ and the row effect $j$ divided by the grand mean), and transformed according to the slope of the regression line. In this case, the slope was -1.2 , which calls for squaring the original data in order to assess the "true" row effect (see Tukey, Vol. III). The final two-way midmean table, after readjusting signs, was:

\begin{tabular}{lrrrrr} 
& 1 & \multicolumn{1}{c}{2} & 3 & \multicolumn{1}{c}{6} & Row Effects \\
$1969-70$ & -0.19 & -0.01 & 0.00 & 0.07 & 0.03 \\
$1970-71$ & -0.04 & 0.03 & 0.05 & -0.12 & 0.07 \\
$1971-72$ & -0.01 & 0.02 & -0.04 & 0.01 & 0.08 \\
$1972-73$ & 0.09 & -0.05 & -0.02 & 0.01 & $\underline{-0.18}$ \\
Column effects & 0.18 & 0.11 & -0.13 & -0.16 & -0.27
\end{tabular}

In interdistrictstandard deviations, this row effect can be reexpressed as follows: if the entire Alum Rock district performed as the voucher schools did, the district would have dropped about one-third of a standard deviation compared with other districts in California. (This result is based on tables provided by the State of California.)

\section{COMPARING VOUCHER AND NONVOUCHER SCHOOLS}

Perhaps the drop in reading scores observed in the voucher schools was due to some more general drop throughout the Alum Rock district. This hypothesis would attribute the losses in voucher schools not to the voucher demonstration but to other factors operating throughout the district.

Figure VIII-B.1 displays stem-and-leaf diagrams for all Alum Rock schools, by grade, in 1971-72 and in 1972-73. (The units are tenths of an interstudent standard deviation.) The scores of voucher schools are circled. In this figure one can roughly assess the relative and absolute shifts of voucher and nonvoucher schools over that one-year span. (This disparity in the number of schools having sixth grades reflects the expansion of two schools and the opening of one new one.) In every case, the voucher schools have dropped relative to the nonvoucher schools in Alum Rock.

How have the nonvoucher schools performed over time? Table VIII-B.5 presents the parallel to Table VIII-B.3 for the nonvoucher schools. There appears to be no time trend in any grade. Interestingly, the $1972-73$ row effect is slightly positive, as Table VIII-B.6, showing the two-way analysis of variance of the data in Table VIIIB.5, indicates. Compare these results with those in Table VIII-B.4. Again, two-way midmean analysis reinforced this finding. The first iteration yielded:

\begin{tabular}{lrrrrr} 
& 1 & 2 & 3 & \multicolumn{1}{c}{6} & Row Effects \\
$1969-70$ & -0.02 & 0.03 & 0.14 & -0.07 & 0.04 \\
$1970-71$ & -0.05 & 0.04 & 0.01 & 0.05 & -0.01 \\
$1971-72$ & 0.04 & -0.04 & -0.01 & 0.10 & -0.03 \\
$1972-73$ & 0.18 & 0.01 & -0.01 & -0.03 & $\underline{0.01}$ \\
Column effects & 0.10 & 0.05 & -0.11 & -0.04 & -0.47
\end{tabular}




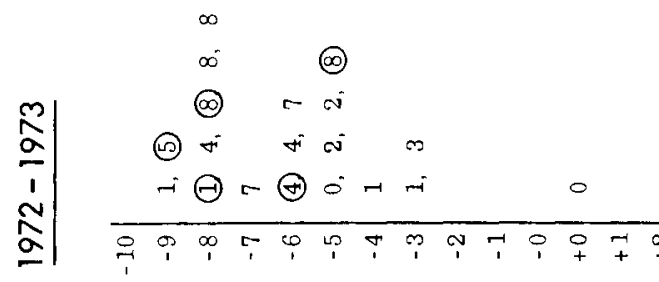

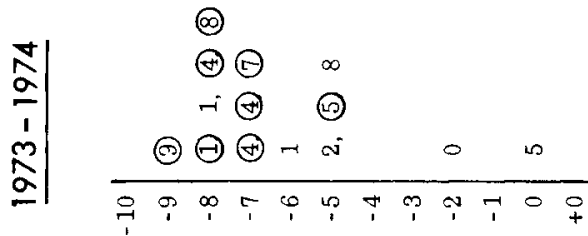

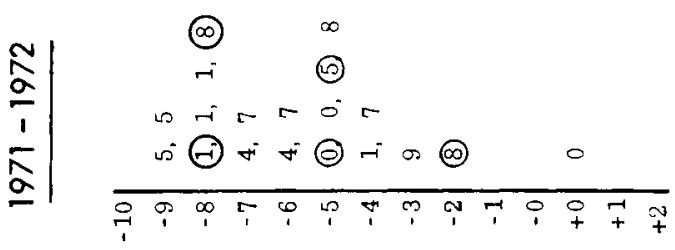

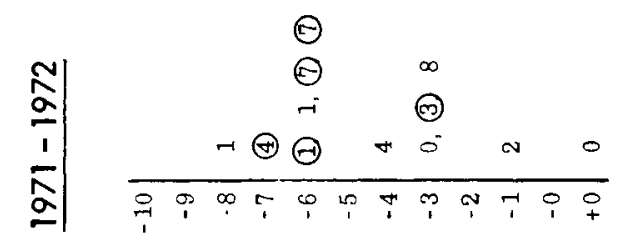

밍

点

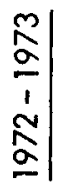

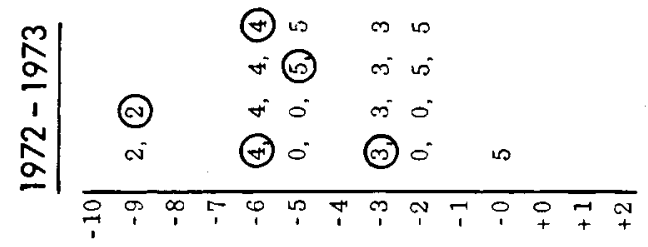

อ

象

พํำ

:

แั

돈

ह 옹

敢

$\frac{N}{\frac{N}{a}}$

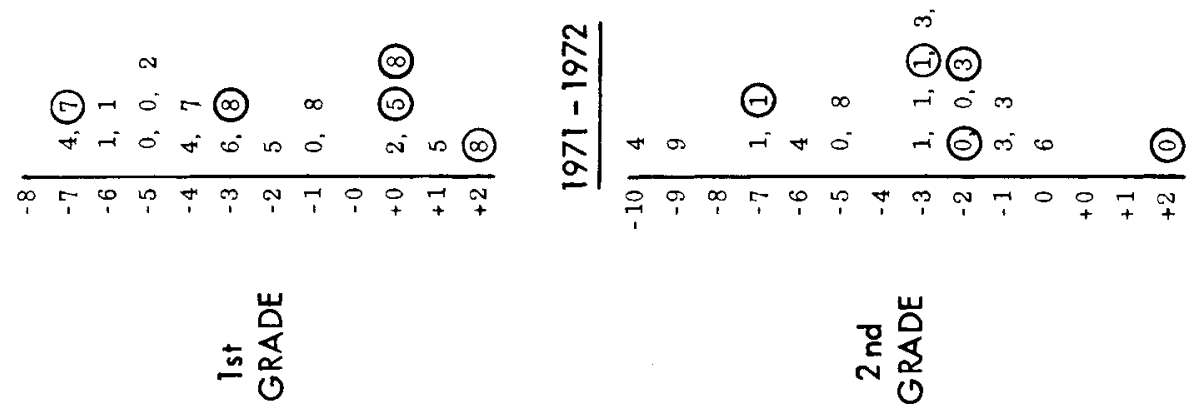


Table VIII-B. 5

\begin{tabular}{|c|c|c|c|c|}
\hline \multirow[b]{2}{*}{ Year } & \multicolumn{4}{|c|}{ Grade } \\
\hline & 1 & 2 & 3 & 6 \\
\hline $\begin{array}{l}1969-70 \\
1970-71 \\
1971-72 \\
1972-73 \\
1973-74\end{array}$ & $\begin{array}{l}-0.36 \\
-0.44 \\
-0.36 \\
-0.19\end{array}$ & $\begin{array}{l}-0.36 \\
-0.40 \\
-0.49 \\
-0.41\end{array}$ & $\begin{array}{l}-0.41 \\
-0.59 \\
-0.62 \\
-0.59\end{array}$ & $\begin{array}{l}-0.55 \\
-0.48 \\
-0.44 \\
-0.50 \\
-0.54\end{array}$ \\
\hline
\end{tabular}

Table VIII-B.6

TWO-WAY ANALYSIS OF VARIANCE, NONVOUCHER SCHOOLS IN ALUM ROCK, $1969-70$ TO $1972-73$

\begin{tabular}{|c|c|c|c|c|c|}
\hline \multirow[b]{2}{*}{ Yeat } & \multicolumn{4}{|c|}{ Grade } & \multirow[b]{2}{*}{ Row Effects } \\
\hline & 1 & 2 & 3 & 6 & \\
\hline $1969-70$ & -0.05 & 0.02 & 0.11 & -0.08 & 0.03 \\
\hline $1970-71$ & -0.08 & 0.04 & -0.01 & 0.05 & -0.03 \\
\hline $1971-72$ & 0.00 & -0.05 & -0.04 & 0.09 & -0.03 \\
\hline $1972-73$ & 0.13 & -0.01 & -0.06 & -0.06 & 0.02 \\
\hline Column effects & 0.11 & 0.04 & -0.10 & -0.05 & -0.45 \\
\hline
\end{tabular}

NOTE: Sixth grade score for $1972-73$ is actually the score from the fall 1973 testing.

The regression of cell residuals against plotting values yielded a slope of -4.7 , calling for a transformation of the original data to squares. This done, the final two-way midmean analysis, with signs corrected, was:

$\begin{array}{lrrrrr}1969-70 & -0.02 & 0.02 & 0.15 & -0.07 & 0.03 \\ 1970-71 & -0.05 & 0.02 & 0.01 & 0.04 & -0.01 \\ 1971-72 & 0.04 & -0.03 & -0.01 & 0.10 & -0.03 \\ 1972-73 & 0.09 & -0.01 & -0.01 & -0.04 & -0.01 \\ \text { Column effects } & 0.09 & 0.06 & -0.12 & -0.03 & -0.23\end{array}$

There was, then, virtually no overall change in 1972-73 from previous reading test score averages in the nonvoucher schools.

Given the overall variation in Table VIII-B.5, however, it is best to conclude that, unlike the results for the voucher schools, there is no significant 1972-73 row effect for the nonvoucher schools.

These results lead one to conclude that the drop in achievement scores witnessed in the voucher schools cannot be explained by an overall drop in the scores of the Alum Rock district as a whole. In the five Title I schools in 1972-73, there was 
apparently no significant overall gain or loss in reading scores. Of the fifteen first, second, and third grade scores, nine were higher, five lower, and one stayed the same; on average the first grade scores dropped slightly, and the second and third grade scores went up. The Title I schools as a whole had lower scores than the voucher schools in 1971-72, but after the first year of the demonstration, the voucher schools were lower in every grade for which comparisons could be made. (There was only one Title I sixth grade in 1972-73.) Here are the Title I school scores:

\begin{tabular}{|c|c|c|c|c|c|}
\hline & & 1 & 2 & 3 & 6 \\
\hline Arbuckle & $\begin{array}{l}1970-71 \\
1971-72 \\
1972-73\end{array}$ & $\begin{array}{l}-0.553 \\
-0.100 \\
-0.050\end{array}$ & $\begin{array}{l}-0.467 \\
-0.643 \\
-0.331\end{array}$ & $\begin{array}{l}-0.878 \\
-0.772 \\
-0.772\end{array}$ & $\begin{array}{l}-- \\
-- \\
--\end{array}$ \\
\hline Hubbard & $\begin{array}{l}1970-71 \\
1971-72 \\
1972-73\end{array}$ & $\begin{array}{r}-0.025 \\
0.025 \\
-0.125\end{array}$ & $\begin{array}{l}-0.495 \\
-0.202 \\
-0.331\end{array}$ & $\begin{array}{l}-0.524 \\
-0.643 \\
-0.412\end{array}$ & $\begin{array}{c}-- \\
-- \\
-0.674\end{array}$ \\
\hline Mayfair & $\begin{array}{l}1970-71 \\
1971-72 \\
1972-73\end{array}$ & $\begin{array}{l}-0.994 \\
-0.253 \\
-0.553\end{array}$ & $\begin{array}{l}-1.126 \\
-0.706 \\
-0.495\end{array}$ & $\begin{array}{l}-0.841 \\
-0.954 \\
-0.878\end{array}$ & $\begin{array}{l}-- \\
--\end{array}$ \\
\hline San Antonio & $\begin{array}{l}1970-71 \\
1971-72 \\
1972-73\end{array}$ & $\begin{array}{l}0.279 \\
0.151 \\
0.025\end{array}$ & $\begin{array}{l}+0.772 \\
-0.643 \\
-0.915\end{array}$ & $\begin{array}{l}-0.467 \\
-0.674 \\
-0.524\end{array}$ & $\begin{array}{l}-- \\
-- \\
--\end{array}$ \\
\hline Slonaker & $\begin{array}{l}1970-71 \\
1971-72 \\
1972-73\end{array}$ & $\begin{array}{l}-1.080 \\
-0.739 \\
-0.253\end{array}$ & $\begin{array}{l}-0.612 \\
-1.036 \\
-0.643\end{array}$ & $\begin{array}{l}-0.841 \\
-0.954 \\
-0.915\end{array}$ & $\begin{array}{l}-- \\
-- \\
--\end{array}$ \\
\hline
\end{tabular}

The average scores over all Title I schools for the past three years are:

$\begin{array}{cccc} & 1 & 2 & 3 \\ 1970-71 & -0.586 & -0.386 & -0.710 \\ 1971-72 & -0.183 & -0.646 & -0.799 \\ 1972-73 & -0.191 & -0.543 & -0.700\end{array}$

Grade-equivalent (GE) and raw scores are provided below, so that the 1972-73 performances of voucher and Title I schools on the Cooperative Primary Reading Test can be compared with their scores on the Metropolitan Achievement Test, as given in Appendix VIII-C.

\begin{tabular}{|c|c|c|c|c|c|c|}
\hline \multirow{2}{*}{ Voucher Schools } & \multicolumn{2}{|l|}{1} & 2 & \multicolumn{3}{|c|}{3} \\
\hline & Raw & $\mathrm{GE}$ & Raw & GE & Raw & GE \\
\hline Casse 11 & 18.7 & 1.5 & 19.7 & 2.1 & 28.3 & 2.7 \\
\hline Goss & 0.5 & 1.7 & 22.3 & 2.3 & 29.1 & 2.8 \\
\hline McCollam & 19.5 & 1.7 & 21.7 & 2.3 & 31.6 & 3.2 \\
\hline Meyer & 24.4 & 1.8 & 24.5 & 2.5 & 31.0 & 3.0 \\
\hline \multirow[t]{2}{*}{ Miller } & 20.5 & $\underline{1.7}$ & 21.4 & 2.2 & $\underline{27.6}$ & $\underline{2.7}$ \\
\hline & 20.72 & 1.7 & 21.92 & 2.3 & 29.52 & 2.9 \\
\hline \multicolumn{7}{|l|}{ Iitle I Schools } \\
\hline Arbuckle & 23.8 & 1.8 & 24.3 & 2.5 & 27.6 & 2.7 \\
\hline Hubbard & 23.0 & 1.8 & 24.5 & 2.5 & 33.5 & 3.3 \\
\hline Mayfair & 19.6 & 1.7 & 22.9 & 2.4 & 28.4 & 2.7 \\
\hline & 24.6 & 1.9 & 19.5 & 2.1 & 32.3 & 3.1 \\
\hline \multirow[t]{2}{*}{ Slonaker } & 21.8 & 1.8 & 21.6 & $\underline{2.3}$ & 28.1 & 2.7 \\
\hline & 22.56 & 1.8 & 22.58 & 2.4 & 29.98 & 2.9 \\
\hline
\end{tabular}




\section{CONTROLLING FOR SOCIOECONOMIC DIFFERENCES}

Other explanations for the drop in the scores in voucher schools might be suggested. For example, suppose the introduction of the voucher program was accompanied by changes in the socioeconomic and demographic characteristics of the students in voucher schools. If these changes themselves led to lower scores on reading tests, then the voucher demonstration could not legitimately be held responsible for the losses.

Unfortunately, the California data provide little in the way of socioeconomic information. Along the variables that one can analyze, however, there seems to have been no important change between 1971-72 and 1972-73 for the voucher schools, either absolutely or relative to the other schools in the Alum Rock district. Figure VIII-B.2 provides a gross but useful depiction of the changes along three variables of interest. (The percentage of students receiving free lunches did increase over that year, as previously noted; but relative positions of voucher and nonvoucher schools did not change significantly.)

Rand's analysis of the long-term trends in socioeconomic variables in Alum Rock has uncovered no significant departures during 1972-73. (The analysis will be presented in a forthcoming technical report.)

As a further examination of the influence of socioeconomic variables on achievement scores, I ran a large number of simple and multiple regressions using the limited available Alum Rock data. I checked the explanatory power of the various socioeconomic proxies, experimenting with many transformations and combinations, stratifying the data on some occasions and combining years on others, omitting and including apparent outliers, and using ordinary least squares as well as more resistant fitting techniques. My results can be summarized as follows:

The socioeconomic proxies have very limited predictive power for mean reading scores in grades 1, 2, and 3 in Alum Rock. For the first grade, I could not obtain a reasonable regression line; the only one that came close to statistical significance loaded the percentage of students eligible for free lunches with a positive coefficient (perhaps because of the apparent definitional shifts in that variable over time), and even then under 8 percent of the total variation was explained.

For the second grade, my exertions were again unsuccessful in achieving a fit. The best regression attained a t-statistic of 1.3 (barely significant at the 0.10 level) and explained only about 3 percent of the variation in achievement scores.

For the third grade, the best equation was

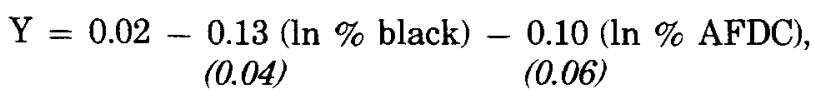

where $\mathrm{Y}$ is the mean achievement score for the third grade (in Alum Rock schools from 1970-71 through 1972-73, excluding the five voucher schools in 1972-73 only), and the figures beneath the regression coefficient are the standard errors of the coefficients. $\mathrm{R}^{2}=0.35$; standard error of the dependent variable $=0.18 ; \mathrm{N}=51$. One outlying observation was omitted to calculate this fit.

Good predictions could be made of past sixth grade scores, but data limitations precluded detailed analysis. Using transformations of the Lorge-Thorndike IQ test and the ethnic variables, I could explain about 92 percent of the variance in grade 6 mean scores, 1969-70 through 1972-73. However, the Lorge-Thorndike test correlates so highly statewide with the sixth grade reading scores $(\rho=0.92)$ that one suspects it is merely another sort of achievement test. Furthermore, the LorgeThorndike test was not given in Alum Rock in the fall of 1973-74. One is left with a questionable prediction equation that is useful only to analyze reading scores that 
\% Mexican-American

$\underline{1971-1972}$

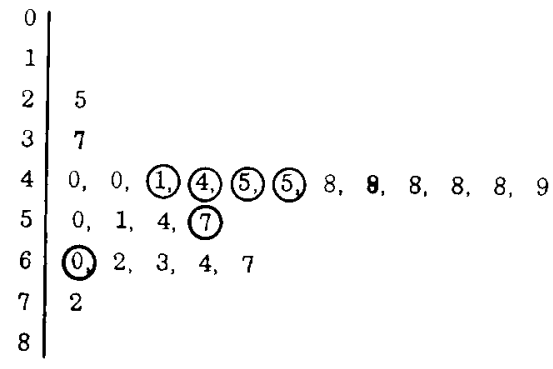

$\%$ Black

$\underline{1971-1972}$
$1972-1973$

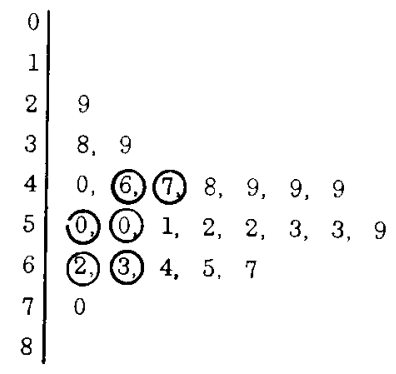

$1972-1973$

\begin{tabular}{|c|c|}
\hline $0-5$ & $2,3,4,5$ \\
\hline $6-10$ & (5) 6,7, (8) $8,8,9$, \\
\hline 15 & 2 , (2) (3) (3) 3,3, (5) \\
\hline & $6,6,8$ \\
\hline & \\
\hline
\end{tabular}

$\%$ AFDC

$1971-1972$

$\underline{1972-1973}$

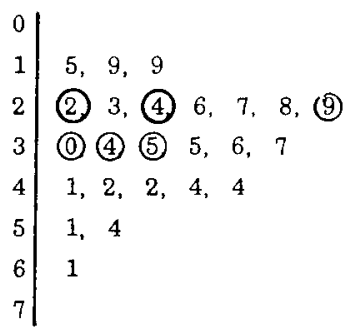

NOTE: The scores of voucher schools are circled

Fig. VIII-B.2-Stem-and-leaf diagrams of socioeconomic proxies for Alum Rock schools, 1971-72 and 1972-73 
were obtained after two months of the voucher demonstration (i.e., fall 1972-73). For what it is worth, the voucher schools in 1972-73 performed worse than the nonvoucher schools in the same year, compared with what would be expected on the basis of previous years after controlling for IQ and the natural logarithm of the percentage of black students. Ranking the residuals in order, with eleven nonvoucher and five voucher schools, resulted in the following picture (where X's indicate voucher schools):

$$
\begin{array}{lcccccccccccccccc}
\text { Rank } & 1 & 2 & 3 & 4 & 5 & 6 & 7 & 8 & 9 & 10 & 11 & 12 & 13 & 14 & 15 & 16 \\
\text { School } & \mathrm{X} & 0 & 0 & 0 & 0 & 0 & 0 & 0 & 0 & 0 & 0 & \mathrm{X} & 0 & \mathrm{X} & \mathrm{X} & \mathrm{X}
\end{array}
$$

The probability of such a ranking occurring by chance in two such samples from the same distribution can be gauged using a Mann-Whitney test, the result being

$$
\begin{aligned}
& \mathrm{z}=\frac{\mathrm{t}-1 / 2-\mu_{\mathrm{T}}}{\sigma_{\mathrm{T}}}=\frac{58-1 / 2-42.5}{8.83} \cong 1.7, \\
& \mathrm{P}(\mathrm{Z}>\mathrm{z})<0.05 .
\end{aligned}
$$

The average difference between voucher and nonvoucher schools after controlling amounted, in grade-equivalent terms, to about two months. However, given the shortcomings mentioned earlier, it is probably best to discount these findings.

One can also make fairly good predictions of sixth grade scores using only the socioeconomic proxies $\left(\mathrm{R}^{2}>0.6\right)$, but the equation must make use of the AFDC percentage. Since this statistic is not yet available for the 1973-74 school year, such an equation is fruitless in analyzing the more recent (and more meaningful) sixth grade scores.

Regression results were consistent with the earlier picture of a drop of about 0.15 to 0.20 of an interstudent standard deviation in the voucher schools during 1972-73. For example, a dummy variable was introduced for the voucher schools during the voucher years. The coefficients were -0.12 for the first grade, -0.23 for the second, and -0.15 for the third (after controlling for In \% black and In \% AFDC), and despite the small number of voucher observations and the nonmatched samples, the t-statistics reached $0.8,1.6$, and 1.6 , respectively.

More directly, Table VIII-B.7 compares the residual scores (actual minus predicted) over time for each voucher school. A positive score indicates that the school performed above expectation, a negative score that it fell below. (The results for grades 1,2, and 3 only are provided because of the limitations described above on the sixth grade data.) Except for Cassell's first grade, 1972-73 showed a drop in reading score residuals in all grades in all voucher schools. Table VIII-B.8 provides the average voucher school scores over time, and Table VIII-B.9 shows the results of a two-way analysis of variance of these data. Once again, the result is that the voucher schools dropped during 1972-73. Row effects are nonzero at the 0.003 level. Two-way midmean analysis again yielded similar results:

$\begin{array}{lcccc} & 1 & 2 & 3 & \text { Row Effects } \\ 1970-71 & 0.00 & 0.00 & -0.03 & 0.10 \\ 1971-72 & 0.00 & 0.00 & 0.00 & 0.08 \\ 1972-73 & 0.00 & -0.10 & 0.04 & -0.19 \\ \text { Column effects } & 0.01 & 0.03 & -0.04 & 0.05\end{array}$


Table VIII-B.7

RESIDUAL SCORES FOR VOUCHER SCHOOLS

\begin{tabular}{l|r|r|r|r}
\hline \multirow{2}{*}{ School } & & \multicolumn{3}{|c}{ Grade } \\
\cline { 3 - 5 } Casse11 & Year & 1 & 2 & \multicolumn{1}{c}{3} \\
\hline \multirow{4}{*}{ Goss } & 1971 & -0.38 & 0 & -0.22 \\
& 1972 & -0.48 & -0.30 & -0.11 \\
& 1973 & -0.41 & -0.51 & -0.23 \\
& 1971 & 0.60 & 0.56 & 0.34 \\
McCollam & 1972 & 0.34 & 0.61 & 0.23 \\
& 1973 & -0.12 & -0.14 & -0.13 \\
& 1971 & -0.07 & 0 & 0.15 \\
Meyer & 1972 & -0.09 & 0.10 & 0.43 \\
& 1973 & -0.26 & -0.24 & -0.01 \\
& 1971 & 0.12 & 0.02 & 0.06 \\
& 1972 & 0.57 & 0.18 & 0.11 \\
& 1973 & 0.29 & 0.08 & 0.02 \\
Miller & 1971 & 0.57 & 0.33 & 0.08 \\
& 1972 & 0.37 & 0.21 & -0.20 \\
& 1973 & -0.12 & -0.24 & -0.31 \\
\hline
\end{tabular}

NOTE: Units are interstudent standard deviations.

Table VIII-B.8

AVERAGE RESIDUAL SCORES IN VOUCHER SCHOOLS: ACTUAL MINUS PREDICTED NORMALIZED SCORES

\begin{tabular}{l|c|c|c}
\hline \multirow{2}{*}{ Year } & \multicolumn{3}{|c}{ Grade } \\
\cline { 2 - 4 } & 1 & 2 & 3 \\
\hline $1970-71$ & +0.17 & +0.18 & +0.08 \\
$1971-72$ & +0.14 & +0.16 & +0.09 \\
$1972-73$ & -0.12 & -0.21 & -0.13 \\
\hline
\end{tabular}

Table VIII-B.9

TWO-WAY ANALYSIS OF VARIANCE: VOUCHER SCHOOL RESIDUAL SCORES

\begin{tabular}{l|r|r|r|r}
\hline \multirow{2}{*}{\multicolumn{1}{c|}{ Year }} & \multicolumn{3}{|c|}{ Grade } & \multirow{2}{*}{ Row Effects } \\
\cline { 2 - 4 } $1970-71$ & 1 & 2 & 3 & \multicolumn{1}{c|}{0.10} \\
$1971-72$ & 0.00 & 0.03 & -0.04 & \multicolumn{1}{c|}{0.09} \\
$1972-73$ & -0.01 & 0.02 & -0.01 & $\begin{array}{r}0.20 \\
\text { Column effects }\end{array}$ \\
\hline
\end{tabular}


No need was found for further iterations.

How did these results compare with those for the nonvoucher schools? Table VIII-B.10 gives the results of a two-way analysis of variance of the average residual scores in nonvoucher schools from 1970-71 to 1972-73, grades 1, 2, and 3. In contrast to the voucher schools, the nonvoucher schools showed no significant drop in 197273 ; in fact, they gained a bit. Once again, the two-way midmean analysis supported the finding of the two-way analysis of variance. The corresponding 1972-73 row effect was also 0.04 .

Table VIII-B. 10

TWO-WAY ANALYSIS OF VARIANCE: NONVOUCHER SCHOOL RESIDUAL SCORES

\begin{tabular}{l|r|r|r|c}
\hline \multirow{2}{*}{\multicolumn{1}{c|}{ Year }} & \multicolumn{3}{|c|}{ Grade } & \multirow{2}{*}{ Row Effects } \\
\cline { 2 - 5 } \multicolumn{1}{c|}{1} & \multicolumn{1}{c|}{2} & \multicolumn{1}{c|}{3} & Row Ef \\
\hline $1970-71$ & -0.07 & 0.04 & 0.03 & -0.02 \\
$1971-72$ & 0.09 & -0.02 & -0.06 & -0.02 \\
$1972-73$ & -0.01 & -0.01 & 0.03 & 0.04 \\
Column effects & -0.04 & 0.00 & 0.03 & -0.03 \\
\hline
\end{tabular}

\section{CONCLUSIONS}

Voucher schools recorded lower average reading scores in every grade in 1972-73 than in previous years, while nonvoucher schools stayed about the same. This result held even after controlling for the limited socioeconomic information available on Alum Rock schools from the State of California.

How should one interpret this result? Two questions arise: How large was the drop? How significant is it from the standpoint of assessing the voucher experiment or, more broadly, for educational policy?

How large were the losses? In terms of interstudent standard deviations, the average drop in the reading scores in voucher schools across all grades tested was 0.15 to 0.20 . In interdistrict terms, the drop was about one-third of a standard deviation.

Reexpressing these two equivalent results in percentiles, if a student performed at the 50th percentile before and dropped 0.15 to 0.20 of a standard deviation, he would end up at the 42 nd to 44 th percentile. If a district were at the 50 th percentile in interdistrict terms and fell by a third of a standard deviation, it would be about the 37 th percentile.

What about grade equivalents? They are of little use in the first, second, and third grades, because there is so little variability in grade equivalent scores and because "floor effects" are so important. (For example, the 50th interstudent percentile on first grade scores in California in 1972-73 was "equal" to 1.8 in the publisher's grade equivalent; but the 25th percentile was only a drop to a score of 1.6.) For what it is worth, for the first, second, and third grades, 0.15 to 0.20 of a standard deviation is in no case more than two months in grade equivalent terms.

The second question-the significance of these results for an assessment of the voucher demonstration-clearly transcends mere numbers. There is first of all a 
value judgment as to "how much" such a drop matters. Do decisions about the continuation or the desired size of the demonstration depend on increased achievement scores? Second, there are obvious difficulties in assessing any new and diversified program after only one year of operation and using only broad comparisons of average scores. More discriminating analyses, after more time has passed and more data have been collected, will of course be necessary to gauge the true effects on achievement scores. 


\title{
Appendix VIII-C \\ PRELIMINARY ANALYSIS OF METROPOLITAN ACHIEVEMENT TEST SCORES, VOUCHER AND TITLE I SCHOOLS, $1972-73^{1}$
}

\author{
by Pierce Barker
}

\section{INTRODUCTION}

Cronbach and Furby asserted in 1970 that, given a nonequivalent control group design, "What cannot be done is to compare "treatment effects." If we take that rather dogmatic pronouncement completely seriously, we educational researchers, given the present state of the art, must throw in our hands. In most field settings, the nonequivalent control group (Campbell and Stanley, 1973) is the best we are likely to get; and if we are to believe that differences between "treatments" in these studies cannot be meaningfully compared, we are wasting our time-we should not be doing the research at all.

The picture need not be as bleak as all that, however; there are situations in which a careful assessment of the context of the research may lead to structural models in which the "treatment effects" can be compared. This appendix investigates that possibility with available achievement test data from the Alum Rock demonstration.

\section{THE SETTING AND THE DATA}

In the fall of 1972 and again in the spring of 1973, Metropolitan Achievement Tests (Harcourt et al., 1971) were administered to five elementary schools designated by the Alum Rock district as Title I schools, and five others in the same district that were participating in the voucher demonstration. The testing was done independently in the two groups of schools, for purposes of evaluation of the two progams; the spring testing was done in the two groups roughly contemporaneously, while in the fall, the voucher schools were tested six weeks later than the Title I schools.

One clear difference in the testing situations must be described, although its effect cannot be estimated. In the Title I schools, the test designated by the publisher on the basis of national norms as appropriate for any grade (k) was administered to all students in that grade; that is, all testing was "in-level." In the voucher schools, however, teachers were permitted to give to each student a test designed for the grade at which, in the teacher's judgment, the student was actually achieving or was capable of handling. The result was that it was not unusual for students enrolled in a grade $(\mathrm{k})$ to be given tests $d \epsilon$ signed for grades $(\mathrm{k} \pm 2)$. In order to compare student's marks on these tests among themselves or across grades or groups, it was necessary to convert the raw scores to a common base. In the case of the MAT, this

\footnotetext{
1 The author gratefully acknowledges the advice and assistance of Professor Finis Welch of the Economics Department, UCLA, and The Rand Corporation. He managed to convert a piece of panicky drudgery into an occasion of learning; but he is not, of course, in any way responsible for the use made of his advice, nor for errors in this piece.
} 
common base is the Grade Equivalent (GE) scale. It is not clear, however, that the conversion algorithm worked out by the publisher on a national sample is suitable for a sample consisting largely of low-achieving students. On the basis of some preliminary data gathered to assess the accuracy of the conversion for Alum Rock students, it is possible to say that the standard conversion algorithm produced aggregate scores for a set of third grade students, given both the third grade and second grade tests in randomly counterbalanced order, which were accurate to about $0.2 \mathrm{GE}$ units or less (95 percent confidence limits). (This study is described in full in Barker, forthcoming,) Consequently, while this problem does not seem on the basis of preliminary analysis to be severe, it should be borne in mind in considering the results of the present analysis.

Since most voucher first graders were given the lowest level of the MAT (the Primer), which does not translate to GE units, only the second through fifth grade results are included here. The data for Title I schools were available only in condensed form; consequently, all analysis is based on school means by grade. Since the results for reading and math are very similar, only the reading scores are considered here.

The basic data matrix upon which all subsequent analysis is based is shown in Table VIII-C.1.

\section{STATEMENT OF THE PROBLEM}

The Title I program, like a great many state and federally-funded educational programs, is compensatory; it is intended to aid disadvantaged students to improve their level of academic achievement. Title I students, in school districts which opt to designate individuals, are selected on the basis of an economic indicator of relative poverty. Districts may, however, choose to designate entire schools as Title I schools, and the criterion again is economic; specifically, schools are chosen based upon the proportion of students in a school who are from families on welfare. Operationally, designation of Title I status is based on an annual census of students who are eligible for AFDC (Aid to Families with Dependent Children); Title I schools in any district typically are those for which the proportion of AFDC recipients is highest. That is, selection as a Title I school is a consequence of a group characteristic, not a characteristic of individual students; moreover, selection is not explicitly based on individual or group academic achievement, however measured. It is, of course, commonplace that socioeconomic status (SES), of which eligibility for AFDC is considered a valid indicator or proxy, is negatively correlated with academic achievement; still, we emphasize that achievement per se is not the basis for selection.

Now, the central problem of causal inference in nonexperimental settings, particularly for the nonequivalent control group design, is precisely the composition of the groups by a process of deliberate selection. In a randomized ("true") experimental design, however complex, the central justification for causal inference from group differences ("treatments") to observed effects on the dependent variable(s) is that, by design, differences among group other than the treatments are correlated with the treatments only by chance.

"In a fully randomized experiment, the covariates have only a small chance correlation with the experimental treatments and hence the expectation of the statistical [covariance] adjustment is zero." (O'Connor, 1973, p. 4)

More specifically, in a pre-posttest design, the expected value of the correlation between the treatment and the pretest is zero; and this is also true of the correlation 
Table VIII-C.I

MEAN PRETEST AND POSTTEST READING SCORES FOR VOUCHER AND TITLE I SCHOOLS, BY GRADE LEVEL

\begin{tabular}{|c|c|c|c|c|c|c|c|c|c|c|}
\hline \multirow[b]{2}{*}{ Grade $^{a}$} & \multicolumn{4}{|c|}{ Fa11 1972} & \multicolumn{4}{|c|}{ Spring 1973} & \multicolumn{2}{|c|}{ Gain } \\
\hline & V & $\mathrm{n}$ & $\mathrm{T}$ & $\mathrm{n}$ & V & $\mathrm{n}$ & $\mathrm{T}$ & $\mathbf{n}$ & $\mathrm{v}$ & $\mathrm{T}$ \\
\hline \multirow{5}{*}{2} & 15 & 51 & 1.52 & 109 & 2.59 & 60 & 2.06 & 109 & 0.44 & 0.54 \\
\hline & 1.97 & 40 & 1.56 & 80 & 2.60 & 43 & 2.26 & 80 & 0.63 & 0.70 \\
\hline & 2.08 & 60 & 1.48 & 112 & 2.80 & 56 & 2.11 & 112 & 0.72 & 0.63 \\
\hline & 2.11 & 59 & 1.54 & 63 & 2.54 & 64 & 2.24 & 63 & 0.43 & 0.67 \\
\hline & 2.06 & 32 & 1.50 & 87 & 2.43 & 40 & 2.20 & 87 & 0.37 & 0.70 \\
\hline \multirow{3}{*}{$\operatorname{Mean}^{b}$} & $\overline{2.08}$ & $\overline{242}$ & $\overline{1.52}$ & $\overline{451}$ & $\overline{2.59}$ & $\overline{252}$ & $\overline{2.16}$ & $\overline{451}$ & $\overline{0.51}$ & $\overline{0.64}$ \\
\hline & 3.09 & 90 & 2.23 & 108 & 3.59 & 102 & 2.73 & 108 & 0.50 & 0.50 \\
\hline & 2.59 & 55 & 2.26 & 90 & 2.88 & 68 & 3.17 & 90 & 0.29 & 0.91 \\
\hline \multirow[t]{3}{*}{3} & 2.36 & 61 & 2.14 & 95 & 3.06 & 85 & 2.52 & 95 & 0.70 & 0.38 \\
\hline & 2.57 & 87 & 2.12 & 49 & 3.07 & 89 & 3.10 & 49 & 0.50 & 0.98 \\
\hline & 2.40 & 60 & 2.07 & 80 & 3.07 & 48 & 2.53 & 80 & 0.67 & 0.46 \\
\hline \multirow[t]{3}{*}{ Mean } & $\overline{2.64}$ & $\overline{353}$ & $\overline{2.17}$ & $\overline{422}$ & 3.17 & $\overline{392}$ & $\overline{2.78}$ & $\overline{422}$ & 0.53 & $\overline{0.61}$ \\
\hline & .38 & 74 & 2.50 & 99 & 3.80 & 76 & 2.95 & 99 & 0.42 & 0 . \\
\hline & 2.83 & 62 & 2.56 & 91 & 3.24 & 70 & 3.24 & 91 & 0.41 & 0.68 \\
\hline \multirow[t]{3}{*}{4} & 2.91 & 97 & 2.48 & 100 & 3.51 & 106 & 2.85 & 100 & 0.61 & 0.37 \\
\hline & 3.27 & 71 & 2.47 & 50 & 3.45 & 82 & 3.10 & 50 & 0.28 & 0.53 \\
\hline & 2.77 & 51 & 2.46 & 71 & 3.13 & 42 & 3.30 & 71 & 0.36 & 0.84 \\
\hline \multirow[t]{3}{*}{ Mean } & $\overline{3.05}$ & $\overline{355}$ & $\overline{2.50}$ & $\overrightarrow{411}$ & $\overline{3.56}$ & $\overline{376}$ & $\overline{3.07}$ & $\overline{411}$ & $\overline{0.51}$ & $\overline{0.57}$ \\
\hline & 4.37 & 83 & 3.11 & 80 & 5.05 & 103 & 3.68 & 80 & 0.68 & 0.59 \\
\hline & 3.64 & 75 & 3.26 & 69 & 3.92 & 81 & 3. & 69 & 0.28 & 0.42 \\
\hline \multirow[t]{3}{*}{5} & 3.55 & 98 & 3.22 & 91 & 4.17 & 104 & 3.57 & 91 & 0.62 & 0.35 \\
\hline & 3.77 & 87 & 2.80 & 40 & 4.25 & 96 & 3.44 & 40 & 0.48 & 0.64 \\
\hline & 3.67 & 51 & 3.40 & 57 & 4.12 & 52 & 4.20 & 57 & 0.45 & 0.80 \\
\hline Mean & 3.80 & $\overline{394}$ & 3.18 & 337 & $\overline{4.34}$ & $\overline{436}$ & 3.71 & $\overline{337}$ & 0.54 & $\overline{0.53}$ \\
\hline \multicolumn{11}{|c|}{$\begin{array}{l}\text { NOTE: } V=\text { voucher schools, } T=\text { Title I schools. Voucher } \\
\text { school grades have been translated into grade equivalent } \\
\text { units. }\end{array}$} \\
\hline \multicolumn{11}{|c|}{$\begin{array}{l}\text { a The vouch } \\
\text { Miller) and T } \\
\text { Mayfair, Arbuc } \\
\text { this table. }\end{array}$} \\
\hline \multicolumn{11}{|c|}{$\begin{array}{l}\mathrm{b} \text { A1l grade means are unweighted means of school means; } \\
\text { they are based, not upon individual scores, but upon sohool } \\
\text { scores. A check of several sets of scores at random indi- } \\
\text { cates that this procedure will not differ by more than about } \\
+0.02 \text { from the weighted mean based on individual scores. }\end{array}$} \\
\hline
\end{tabular}

between the treatment and any other concomitant variable, measured or unmeasured. The chance correlation is fully allowed for in the test of statistical signifcance; and in those occasional instances when randomization does produce a large correlation between treatment and some measured variable, including the pretest, statistical adjustment by analysis of covariance is perfectly proper, provided the data meet the assumptions underlying the covariance model (Cochran, 1957; Elashoff, 1969; Kenny, 1974).

However, selection for compensatory treatment, on whatever basis made, represents a deliberate, nonchance correlation of some individual and/or group characteristic(s) with the treatments. Specifically, the compensatory educational Title I programs deliberately enroll students, as we have seen, on the basis of a characteristic firmly believed to be correlated with academic achievement; and academic achievement is usually the principal dependent variable in assessments of the 
"effects of the treatment." Said differently, the "treatment" and "control" groups in these programs differ by design on the dependent variable and on the selection variable, so that the "treatment" and the selection variable are deliberately highly correlated: "treatment" and one or more other characteristics of the groups are deliberately confounded. And it is not just the selection characteristic(s), but other, usually unmeasured characteristics, which are also confounded with the treatment. But this means that, in simplest terms, any difference(s) on the posttest(s) between the two groups, which the researcher would like to attribute to the "treatment," may usually plausibly be attributed to nontreatment differences; these are the "plausible rival hypotheses," which Campbell and Stanley (1963) rightly and vividly portray as the betes noirs of non- or quasi-experimental research.

Researchers in education refer to this as the problem of confounding; statisticians and economists (e.g., Goldberger, 1964) are more likely to speak of specification error. The problem is clearly and simply stated by Werts and Linn (1970) as follows:

... if a variable is not included in the regression equation then the assumption is that either it is not an influence on the dependent variable or, if it is an influence, it is uncorrelated with all the independent variables in the equation. Failure to include relevant influences then can in general be expected to result in biased estimates for all the variables studied (p. 18; italics added).

A very clear hypothetical example of this sort of bias appears in O'Connor (1973). Campbell and Erlebacher (1971) make an eloquent suggestive case for the existence of specification bias in evaluation of compensatory education programs; Kenny (1974) documents the existence and assesses the strength and direction of specification bias in real data. In passing, this discussion clarifies the value of random assignment to treatment groups; randomization guarantees within the limits of chance that variables not included in the analysis are uncorrelated with the "variables studied," in particular the treatment variable. Hence, omission of explicit consideration of other variables may affect the sensitivity of the analysis to detect treatment effects, but will not bias the estimates of these effects.

The problem, then, in evaluating the effects of, say, compensatory educational programs designed for deliberately selected individuals, is simply, how can we correctly specify our analytic model, or, how can we ensure, by including explicitly correlated influences, that our estimates of treatment effects are not biased? As we have seen, many skilled and knowledgeable (and influential) researchers say that it simply cannot be done (e.g., Cronbach and Furby, 1970; Lord, 1967).

\section{ONE DISSENTING OPINION AND A MODEL}

Implicit in the work of, for example, Goldberger (1972 (a), (b)) is the notion that, for a given structural model, the existence of bias depends very much upon the criterion or manner of selection of individuals or groups into the "treatment" and "control" (better, "comparison") groups. That is, given that researchers apply one specific model in every situation, their effects estimates will or will not be biased, depending upon the fit of the model to the research context. Put thus baldly, this has the air of tautology; but, given the known and obvious propensity of researchers in this field in fact to use a single model (typically, a covariance model), Goldberger's work is very much to the point.

In a paper soon to be published, Kenny (1974) carries this work a large step forward by proposing a general model of selection and, for several popular analytic 
models, specifying the proper model in terms of the particular criteria by which selections in given situations are made. Briefly, he proposes a model in which the pretest and posttest are causal functions of group, individual, and random variables; and in which the kind of confounding of treatment with selection depends upon selection in terms of one or another of these variables. His expository strategy involves, for the popular analytic models he considers, a determination of which of the null hypotheses goes to zero in the absence of treatment effects. His general model assumes that the posttest is a function of the pretest and the treatment (cf. Werts and Linn, 1970), and that these in turn are functions of group differences (by hypothesis, perfectly stable over time), individual differences (correlated over time but not perfectly stable), and "totally unstable causes ... (errors of measurement)." His model, then, may be viewed as (with variables for convenience in standard form)

$$
\hat{\mathrm{X}}_{2}=\beta_{21 \cdot \mathrm{T}} \mathrm{X}_{1}+{ }_{2 \mathrm{~T} \cdot 1} \mathrm{X}_{\mathrm{T}},
$$

where $\mathrm{X}_{2}=$ score on the posttest

$\mathrm{X}_{1}=$ score on the pretest

$\mathrm{X}_{\mathrm{T}}=$ treatment

$\beta_{21 \cdot \mathrm{T}}=\left(\mathbf{r}_{12}-\mathbf{r}_{1 \mathrm{~T}} \mathbf{r}_{2 \mathrm{~T}}\right) /\left(_{1}-\mathbf{r}_{1 \mathrm{~T}^{2}}{ }^{2}\right)$

$\beta_{2 \mathrm{~T} \bullet 1}=\left(\mathbf{r}_{2 \mathrm{~T}}-\mathbf{r}_{1 \mathrm{~T}} \mathrm{r}_{12}\right) /\left(1-\mathbf{r}_{1 \mathrm{~T}}{ }^{2}\right)$.

And these variables in turn may be expressed as

$$
\begin{aligned}
& \mathrm{X}_{2}=\mathrm{f}\left(\mathrm{G}, \mathrm{Z}_{1}, \mathrm{E}_{1}\right) \\
& \mathrm{X}_{1}=\mathrm{f}\left(\mathrm{G}, Z_{2}, \mathrm{E}_{2}\right) \\
& \mathrm{X}_{\mathrm{T}}=\mathrm{f}\left(\mathrm{G}, \mathrm{Z}_{\mathrm{i}}, \mathrm{E}_{\mathrm{i}}, \mathrm{U}_{\mathrm{j}}\right),
\end{aligned}
$$

where $\mathrm{G}=$ stable group characteristics

$\mathrm{Z}=$ Correlated (over time) individual characteristics

$\mathrm{E}=$ error of measurement

$\mathrm{U}=$ other causes of selection than $\mathrm{G}, \mathrm{Z}$, or $\mathrm{E}$.

The assumption is that

$$
\operatorname{Cov}\left(Q_{i}, R_{i}\right)=0, \quad Q, R \neq Z .
$$

Then it is easy to derive, from these structural equations, expressions for the intercorrelations of the pretest, posttest, and treatment, and hence to write the expressions for the betas.

Now by specifying various selection patterns in terms of G, Z, and E, by permitting the coefficients of one or more of them to equal zero, and setting a "no treatment effect" condition by setting

$$
\beta_{2 \mathrm{~T} \cdot 1}=0
$$

and setting other conditions on $\beta_{21 . T}$, he derives expressions for the null hypotheses of the various popular models which he considers in terms of equalities of various functions of the intercorrelations of the pretest, posttest, and treatment of the reliability of the pretest, and determines, for each selection pattern, which equality holds, thereby determining the proper analytic model for specified modes of selection.

Simply stated, the strategy is this: (1) Given a particular model, say a covariance model, the null hypothesis of no treatment effect yields certain relationships among the mode parameters, and (2) also, given a structural model in terms of selection criteria, which also assumes no treatment effect, allowing selection to vary by cri- 
teria also yields relationships among the model parameter. The proper model for analysis is chosen by determining a match between the deductions from (1) and from (2).

This is a very meager precis of his paper, and does not begin to do justice to the breadth and incisiveness of his treatment. Moreover, for the record, he writes his regression equation in terms of covariances, not correlations; I have chosen to restate it in correlational terms with the feeling that more readers will be familiar with this formulation.

Now, the situation in which the data under consideration were generated seems to provide a rather straightforward and clear example of one of the modes of selection which he considers, i.e., selection on the basis of group characteristics.

Without going into the details of the derivation, we will simply state that selection on the basis of group characteristics, given the model with which we are dealing, indicates that the proper test of the null hypothesis is a test of the equality

$$
\mathbf{r}_{2 \mathrm{~T}}=\mathrm{r}_{1 \mathrm{~T}}
$$

i.e., that the pretest-treatment correlation equals the posttest-treatment correlation. ${ }^{2}$ The model is stated in terms of two groups, a "treatment" and a "control" group, so that the treatment variable $\underline{X}_{T}$ is a binary variable (usually coded $1 / 0$ ) and the correlation of the treatment variable with the (presumably) continuous criterion variables are point-biserial correlations (McNemar, 1969; Nunnally, 1967).

\section{TEST OF THE SELECTION MODEL ON TITLE I/VOUCHER DATA}

The data we are dealing with fit the version of the stated model in that selection of Title I schools is, as noted above, explicitly on the basis of a group, nontestscore variable; in this case, the proportion of students on AFDC as measured by the annual school district census. Our data consist in mean achievement scores on MAT in GE units for fall ("pretest") and spring ("posttest") for the five Title I and the five voucher elementary schools for each grade from second to fifth for the school year 1972-1973, the first year of the voucher demonstration.

Note, however, that for administrative reasons, the fall MAT testing in the voucher schools was delayed (it occurred in November 1972); hence, this is not in the strict sense "pretest," where the pretest score is obtained prior to the treatment (and should be unaffected by it; cf., e.g., Evans and Anastasio, 1968). Again, it is impossible explicitly to allow for this event; we mention it simply as another point of caution when considering the results to follow.

This, then, seems a reasonably realistic realization of the version of the Kenny (1974) model of selection on the basis of group characteristics. As a first cut, we will examine the relevant intercorrelations of the selection variable (proportion in the school on AFDC), the treatment variable, the fall (pretest) and spring (posttest) scores. These correlations appear in Table VIII-C.2.

\footnotetext{
${ }^{2}$ Note that this is a situation in which a great many researchers would reach up to their shelf of Little Jiffies and pull down the covariance model; some others, more sophisticated about these things, might elaborate the covariance model by correcting for unreliability in the pretest (cf., e.g., Cronbach and Furby, 1970 , the most likely source for many researchers of this bit of sophistication). This is not meant to imply that Cronbach and Furby would recommend this model; they, among the most sophisticated of all analysts, precisely would oppose it. However, the notion of correcting for unreliability in such situations received probably widest circulation in their paper. However, given Kenny's model, it is easy to see that either of those models in this instance would yield biased estimates.
} 
Table VIII-C.2

CORRELATIONS FOR GROUP SELECTION MODEI

\begin{tabular}{c|c|c|c|c|c|c|c|c|c}
\hline $\begin{array}{c}\text { Grade } \\
(1)\end{array}$ & $\begin{array}{c}\mathrm{r}, \mathrm{F} \\
(2)\end{array}$ & $\begin{array}{c}\mathrm{A}, \mathrm{S} \\
(3)\end{array}$ & $\begin{array}{c}\mathrm{F}, \mathrm{S} \\
(4)\end{array}$ & $\begin{array}{c}\mathrm{r}, \mathrm{S} \cdot \mathrm{A} \\
(5)\end{array}$ & $\begin{array}{c}\mathrm{T}, \mathrm{T} \\
(6)\end{array}$ & $\begin{array}{c}\mathrm{r}, \mathrm{F} \cdot \mathrm{A} \\
(7)\end{array}$ & $\begin{array}{c}\mathrm{r}, \mathrm{T}, \mathrm{S} \\
(8)\end{array}$ & $\begin{array}{c}\mathrm{r}, \mathrm{T} \cdot \mathrm{A} \\
(9)\end{array}$ & $\begin{array}{c}\mathrm{r} \\
\mathrm{T}, \mathrm{A} \\
(10)\end{array}$ \\
\hline 2 & $-0.89^{3}$ & $-0.82^{2}$ & $0.90^{3}$ & $0.64^{1}$ & $0.99^{3}$ & $0.94^{3}$ & $0.90^{3}$ & $0.66^{1}$ & $-0.87^{3}$ \\
3 & $-0.75^{2}$ & $-0.59^{1}$ & $0.75^{1}$ & $0.58^{1}$ & $0.75^{2}$ & 0.31 & $0.53^{1}$ & 0.05 & $-0.87^{3}$ \\
4 & $-0.84^{2}$ & $-0.79^{2}$ & $0.83^{2}$ & 0.48 & $0.84^{2}$ & 0.40 & $0.64^{1}$ & -0.18 & $-0.87^{3}$ \\
5 & $-0.89^{3}$ & $-0.82^{2}$ & $0.94^{3}$ & $0.81^{2}$ & $0.79^{2}$ & 0.05 & $0.67^{1}$ & -0.17 & $-0.87^{3}$ \\
\hline
\end{tabular}

$\mathrm{A}=$ proportion AFDC students.

$F=$ fall (pre)test.

$\mathrm{C}=$ spring (post) test.

$\mathrm{T}=$ treatment $(1=$ voucher $/ 0=\mathrm{Title} \mathrm{I})$.

$1=0.01<\mathrm{p} \leq 0.05$.

$2=0.001<p \leq 0.01$.

$3=P \leq 0.001$.

$r_{x, y \cdot z}=r$ between $x$ and $y$ partialling $z ; r$ between residuals of $x$ and $y$ after regressing each on $z$.

An immediate notable feature of the data appears in the correlations of AFDC proportion and pretest in column (2) of Table VIII-C.2. It is clear that, on an aggregate basis, selection of academic low-achievers by selecting schools with a high proportion of students on welfare works very nicely. Recalling that all of the correlations are based upon only $\mathrm{N}=10$ units (the ten schools), and that correlations of aggregate data (which do not take account of variability among individuals) are expectably higher than correlations of data on individuals, these correlations are all high (all $\mathrm{p} \leq .01$ ) and negative (the higher the proportion on welfare, the lower the mean achievement score). The correlation of AFDC and treatment in column (10) (since these variables are available only at the school level, the correlation is of course constant across grades) attest to the success of selection and to the degree of confounding of treatment and an almost certainly relevant variable in any causal function for achievement scores (Mosteller and Moynihan, 1972). The treatment-test correlations (columns (6) and (8)) are also predictably high. ${ }^{3}$

On the surface, the indicated comparison would seem to be, for each grade, the correlations in column (6) (treatment-pretest) with those in column (8) (treatmentposttest). But note that, while the latter are uniformly lower than the former, indicating a tendency over the year for the two groups to converge, they are all, especially the treatment-pretest correlation, high and positive (all $\mathrm{p} \leq .01$ ). Also, we know definitely one of the reasons for the size of these correlations: the treatment was deliberately confounded with a potent influence on achievement; and knowing

\footnotetext{
${ }^{3}$ Indeed, the treatment-pretest correlation for Grade 2 is almost unbelievably high (the first entry in column (6): $r_{T}, F=0.99$ ). A quick look at Table VIII-C.1, however, will show what is going on. This is one of those very rare instances wherein the two within-groups distributions are completely nonoverlapping; this, together with the comparatively sr I within-group variance, especially in the Title I group, accounts for the near-perfect correlation. (ci., e.g., Haggard, 1958.)
} 
this, we would be less than imaginative if we did not include this known influence in our model. The evidently wise procedure, then, would be to compare, not the zero-order treatment-test correlations, but the partial correlations, controlling for the known selection variable. This will cost us one degree of freedom in a situation where df's are already very scarce; on the other hand, it is clearly dictated by realism and power considerations.

The partials appear in columns (7) and (9) of Table VIII-C.2; as an eyeball comparison with columns (6) and (8), respectively, readily shows, the results are rather dramatic. Six of the eight partials, as opposed to all of the zero-orders, are not different from zero at any commonly acceptable level of significance (with $\mathrm{df}=$ $7, \mathrm{P}(\mathrm{r} \geq .58)=.05)$; for the abnormally high second grade correlations, the decrease in one of the two is substantial. ${ }^{4}$ Having introduced into our estimation procedure the selection variable, we may proceed to test the null hypothesis of no treatment effect in terms of the null that the treatment-test correlations are equal. ${ }^{5}$

Notice that the two treatment-test correlations are themselves correlated, in the sense of a shared array (McNemar, 1969; Peters and Van Voorhis, 1940; Snedecor and Cochran, 1967). This means, of course, that the standard error of their difference must take account of this correlation, i.e., the standard error is almost certainly less than the square root of the sum of the two variances. Formulae to adjust the standard expressions assuming independence were derived by Pearson and Filon (1898) and are given without derivation in Peters and Van Voorhis (1940). The results of these tests appear in Table VIII-C.3. Perhaps it is worth noting that, while, say 90 percent confidence limits about any of the correlations in the three higher grades would include zero, this will not suffice as a test of the hypothesis that, within any grade, the two correlations estimate a common parameter. That is, it is possible for neither to be significantly different from zero individually, yet for the difference between them to be significantly nonzero.

Although for purposes of this analysis, we could have introduced grade in school as an additional predictor, it seemed clearer to do a separate analysis at each grade level, although the analyses are clearly not independent. As a glance at Table VIII-C.3 shows, however, the results are quite consistent. In no case save the aber-

\footnotetext{
${ }^{4}$ Note that this partialling procedure is not an application of the covariance model. Analysis of covariance mandates within-groups regression of the response variable on the covariate; and an assumption of the model is that the slopes of these within-groups functions estimate a common parameter. Here, on the contrary, the slope estimate is based on the treatment SS, not the error SS or the "error line" (Cochran, 1957). For the treatment-test correlations are not within-groups functions, nor does the model indicate that they should be. Note also that the model assumption that the group selection factor is perfectly stable over time cannot be tested here; the AFDC census is taken only once each year, and this factor was applied to both treatment-test correlations. However, analysis included elsewhere in this report indicates that in fact even year-to-year shifts in this variable are not substantial, and it is unlikely that shifts of the year-to-year magnitude would occur within years, even given the mobility rate of about 30 percent.

${ }^{5}$ Other possible control variables are, we should note, available. These are in the form of additional SES indicators, such as proportions of ethnic minorities and so on. However, it is clear that we can ill afford to spare the degrees of freedom lost by further partialling. Moreover, from our perspective, it seems reasonable to regard these other SES indicators as just that: alternative indicators of a single-factor variable which we might call "poorness." This might suggest that we use scores from the first principal component of the indicator matrix; but, given that the AFDC variable is the selector (and that it is, in that sense, perfectly reliable), we might more reasonably use scores on a factor fixed through the AFDC point. This, however, would inevitably attenuate the factor (as compared with the principal component); and the attenuation would probably be greater than we would expect on the assumption that we had collected the data: these SES indicators are collected at different points in time, for different purposes, and apparently by different people, with no obvious effort or reason to assure comparability. Hence, it seems not only practical, but a somehow neater test of the model to proceed as above.

We should mention that the AFDC control was chosen in advance of looking at the data, simply on the basis of knowledge of the selection process; the estimate, then, should not unduly capitalize on chance, whence lead to abnormal shrinkage in $\mathrm{R}^{2}$ on a replication. (Lord and Novick, 1968; Nunnally, 1967.)
} 
Table VIII-C.3

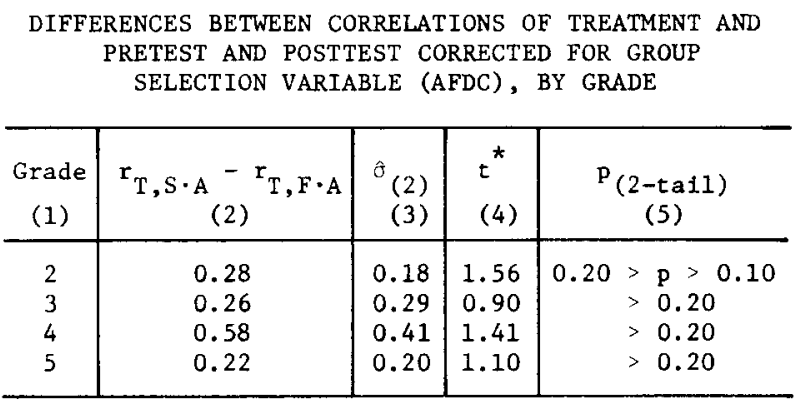

${ }^{\star}{ }_{\mathrm{DF}}=7$.

rant second grade is any value of $t$ greater than about $1.4(\mathrm{p}>.20)$; for the second grade, $\mathrm{t}=1.56(\mathrm{df}=7, .20>\mathrm{p}>.10)$.

In short, the results of the analysis would support the conclusion that we cannot reject the null hypothesis of no treatment effect at any generally acceptable level of significance.

Given this result, of course, it should be borne out by an analysis of the dependent variable, the test scores themselves. The dependent variable in this model will be the difference between standardized scores for spring and fall; and, in view of the introduction of the selection variable as a factor in the equation, the ultimate dependent variable will be the standardized residuals from the between-groups regression of test score on AFDC. The results of these tests appears in Table VIII-C.4. It is well to note that this test, for each grade in turn, is exactly equivalent to a test of the Treatment $\mathrm{x}$ Time interaction for a repeated measures analysis of variance (Cochran, 1972; Green and Tukey, 1960; McNemar, 1969; Winer, 1971). That is, had we formally structured this as an ANOVA model of the repeated measure sort, the Treatment $x$ Time interaction is just a test of the difference between the Treatment groups of the differences between pre- and posttest, which would be the test of interest.

Since the largest value of $t$ is less than 1.00, it is apparent that the results are parallel to those from the previous test; indeed, this test is, demonstration purposes apart, superfluous.

In the end, we find ourselves asking the imperative question of any analysis, have we milked the data dry? In a sense, of course, we have not; a good deal of dredging remains to be done. But, in answer to our principal question: Is there, granted all of our caveats about the situation and the data-is there any apparent reason in the data as given to reject the null hypothesis that there was no significant difference between these two educational treatments? - our three analyses seem to converge: no difference of statistical or practical significance is visible.

Granted, then, that these data are hardly ideal, either in level of aggregation, congruence of conditions of testing, extent in time, and so on; granted all this, what do they seem to tell us about the influence of the voucher demonstration as opposed to the Title I programs? If we take the Title I programs as a base, given that we can control explicitly on the selection factor, each of our analyses indicates that the voucher demonstration had little or no effect, positive or negative, on academic 
Table VIII-C.4

TESTS OF TREATMENT DIFFERENCES IN GROUP SELECTION MODEL

\begin{tabular}{|c|c|c|c|c|c|}
\hline Grade & $\overline{\mathrm{T}}-\overline{\mathrm{V}}$ & $\hat{\mathrm{O}} \overline{\mathrm{T}}-\overline{\mathrm{V}}$ & $t^{\star}$ & $\mathrm{p}$ & $n^{2}$ \\
\hline 2 & -0.246 & 0.527 & -0.47 & $>0.50$ & 0.027 \\
\hline 3 & -0.230 & 0.577 & -0.40 & $>0.50$ & 0.019 \\
\hline 4 & -0.506 & 0.617 & -0.82 & $>0.40$ & 0.078 \\
\hline 5 & -0.190 & 0.386 & -0.49 & $>0.50$ & 0.029 \\
\hline
\end{tabular}

achievement as measured here. These results are prima facie incongruent with the findings reported in Appendix VIII-B, on the basis of a different set of reading tests, mandated by the State of California. Analysis of 1973-1974 data, which include both MAT scores and state-mandated test scores for all voucher and nonvoucher schools in the district, should help to resolve these differences.

If we believe that the confusion attendant upon putting a massively reorganized educational program into the field, and the shorter pre-post interval for the voucher schools, would tend to affect test scores adversely, then we have even stronger reasons to conclude that, whatever the effect (if any) of the demonstration, it did not harm the students sufficiently in the aggregate to depress their scores unduly.

\section{REFERENCES}

Barker, P., Issues in Measuring Student Outcomes, The Rand Corporation, R-1497NIE, forthcoming.

Campbell, D. T., and A. Erlebacher, "How Regression Artifacts in Quasi-Experimental Evaluations Can Mistakenly Make Compensatory Education Harmful," in J. Hellmuth (ed.) The Disadvantaged Child, Vol. 3, Brunner-Hazel, New York, 1971.

Campbell, D. T., and J. S. Stanley, Experimental and Quasi-Experimental Designs for Research, Rand McNally \& Co., Chicago, 1963.

Cochran, W. G., "Analysis of Covariance: Its Nature and Uses, Biometrics, Vol. 13, 1957, pp. 261-281.

_ , "Principal Properties of Multiple Linear Regression," Department of Statistics, Harvard University, 1972 (mimeograph).

Cronbach, L. J., and L. Furby, "How We Should Measure 'Change' or Should We?" Psych. Bull., Vol. 74, No. 1, 1970, pp. 68-80.

Elashoff, J. D., "Analysis of Covariance: A Delicate Instrument," Am. Ed. Res. J., Vol. 6, 1969, pp. 383-402.

Evans, S. H., and E. J. Anastasio, "Misuse of Analysis of Covariance When Treatment Effect and Covariate Are Confounded," Psych. Bull., Vol. 69, 1968, pp. 225-234.

Goldberger, A. S., Econometric Theory, John Wiley and Sons, New York, 1964.

—, "Selection Bias in Evaluating Treatment Effects: Some Formal Illustrations," 
Institute for Research on Poverty, University of Wisconsin, Madison, Wis., Discussion Paper 123-72, 1972 (a).

Green, B. F., and J. Tukey, "Complex Analysis of Variance: General Problems," Psychometrika, Vol. 25, 1960, pp. 127-152.

Haggard, E. A., Intraclass Correlation and the Analysis of Variance, The Dryden Press, New York, 1958.

Harcourt Brace Jovanovich Inc., Metropolitan Achievement Tests, New York, 1971.

Kenny, D. A., "A Quasi-Experimental Approach to Assessing Treatment Effects in the Nonequivalent Control Group Design," Harvard University, 1974 (submitted).

Lord, F. M., "A Paradox in the Interpretation of Group Comparisons, Psych. Bull., Vol. 68, 1967, pp. 304-305.

Lord, F. M., and M. R. Novick, Statistical Theories of Mental Test Scores, AddisonWesley, Reading, Mass., 1968.

McNemar, Q., Psychological Statistics, 4th ed., John Wiley and Sons, New York, 1969.

Mosteller, F., and D. P. Moynihan, On Equality of Educational Opportunity, Random House, New York, 1972.

Nunnally, J. C., Psychometric Theory, McGraw-Hill Book Co., New York, 1967.

O'Connor, E. F., Jr., Unraveling Lord's Paradox: The Appropriate Use of Multiple Regression Analysis in Quasi-Experimental Research, Research Bulletin RB73-53, Educational Testing Service, Princeton, New Jersey, 1973.

Pearson, K., and L. N. G. Filon, "Mathematical Contributions to the Theory of Evolution-IV. On the Probable Errors of Frequency Constants and on the Influence of Random Selection on Variation and Correlation, Transactions of the Royal Society, Series A, Vol. 191, 1898, pp. 229-311.

Peters, C. C., and W. R. Van Voorhis, Statistical Procedures and Their Mathematical Bases, McGraw-Hill Book Co., New York, 1940.

Snedecor, G. W., and W. G. Cochran, Statistical Methods, 6th ed., Iowa State University Press, Ames, Iowa, 1967.

Werts, C. E., and R. L. Linn, "A General Linear Model for Studying Growth, Psych. Bull., Vol. 73, 1970, pp. 17-22.

Winer, B. J., Statistical Principles in Experimental Design, 2nd ed., McGraw-Hill Book Co., New. York, 1971. 


\title{
Appendix VIII-D
}

\section{AFFECTIVE TESTING}

\author{
by Theodore S. Donaldson
}

\section{INTRODUCTION}

Interest in the improvement and measurement of affective states (motivation, attitudes, self esteem, self awareness, happiness, and other personality variables) has steadily increased in recent years, motivated in part by the lack of success in modifying cognitive achievement through "standard" educational innovations. The importance of affective growth is often defended on the basis of two arguments. One view contends that affective factors are important because they are believed to be the major determinant of cognitive achievement, and the other view holds that growth in affective rather than cognitive factors is the more relevant goal of education. These views are certainly not mutually exclusive, and in fact, the distinction between affect and cognition is extremely artificial: attitudes and motivation have strong intrinsic cognitive components, and cognition involves affective components. Piaget and Inhelder (1969), among others, have made a strong argument for considering affect and cognition as "inseparable and irreducible" (p. 158). Recognizing the artificiality in an affective-cognitive dichotomy, we proceed with arguments for including measures of what are called affective factors.

How educational programs might influence affective growth is a matter of much speculation; however, it seems that the expert consensus is that the primary factors in the formation of affective states are in the child's home, and mostly in the early years. A lengthy study by Coopersmith (1967) places the antecedents of self esteem in the home, and Gordon (1970) briefly reviews some of the evidence supporting the relevance of home factors. Very little can be found supporting the notion that affective states can be seriously modified by early school influences. The school can, however, support existing affective predispositions. For example, children with low self esteem may rarely find rewarding and successful experiences in school and their low self esteem is thus supported.

At least part of the reason for the school's lack of success in modifying affective growth is the lack of clearly defined processes that could bring about growth, in spite of often stated objectives to do so. Merely stating that an objective is improving student self esteem says nothing about how it is to be done, and if schools are to bring about affective change, it must be through careful definition of processes which are thought to be effective. It is generally agreed that foremost among these processes is the construction of successful experiences for the early learner, although it is not exactly clear how this can be accomplished, especially in view of the heavy influence of nonschool factors on affective growth and the limitations imposed by the schools' commitment to graded learning.

In any event, to effectively evaluate the influence of an educational program on affective growth would require a careful investigation of the proposed and implemented classroom processes, and the definition of measures which bear on those processes. In this case, comparisons across programs may not be meaningful, unless programs have nearly identical objectives and aspire to the same processes. Regardless of specific objectives, however, it is reasonable to assess the relative influence 
of various affective factors on achievement and to make these comparisons across programs. Further, there are a number of affective factors that seem relevant to all educational programs regardless of stated objectives. Finally, there is a growing and convincing body of evidence showing that affect and cognition are empirically as well as theoretically related-positive affective states are associated with high achievement. Thus, if educational programs do improve affect, achievement should also improve. There is of course some question as to what kind of achievement is measured, and evaluations typically focus on only a narrow range of possible cognitive outcomes.

Even though affect and achievement are correlated, the implementation of programs which aim at affective growth could introduce problems for evaluation in comparing achievement among various types of programs. The graded, fixed curriculum approach to education (in which all first graders are exposed to first grade material, etc.) does not allow for some approaches to affective development. For example, a school which focuses on, say, the development of self esteem through play activities, may show very poor results on reading tests, at least in the early grades; and those programs which do not aspire to a graded curriculum cannot be evaluated by comparison with programs that do so, at all grade levels. In this case one needs to evaluate relatively long-term effects, perhaps looking at achievement scores at the exit of elementary school.

At the present time there is little information on specific voucher educational processes or even what the affective objectives of various programs are. Moreover, even given affective objectives, there is no assurance that the proposed processes are in fact implemented. We would go so far as to say that it is probably impossible for many teachers to implement many affective growth (or other) strategies. Lacking specific information on processes, the approach for the affective component of the evaluation is to attempt to measure several factors which are believed to be generally important, and which are often stated as objectives in innovative programs.

Probably the most widely researched affective component is that of self concept or self esteem, although, as pointed out by Zierkel (1971), there is a proliferation of definitions and measures, and this probably accounts for some of the confusion and inconsistencies in reported results. For example, the relationship between self concept and SES is extremely clouded and many contradictory results can be found. In spite of this, self concept measures are widely used, and low self concept is often associated with learning problems, especially among Mexican-American children (Hernandez, 1973, Leonetti, 1973). Everything considered, measures of self concept appear to be of fundamental importance in the affective battery.

Another affective factor which has received considerable attention is that of students' attitude toward school, and in some cases (especially older children), their expectations and aspirations. One would expect that attitudes toward school would be related to self concept and achievement, although the possibility exists for program effects on one of these factors but not the other. Analysis of changes in the (possibly) complex relationships between self concept, attitude toward school, and programs should prove interesting.

A number of other affective factors appear interesting and important; however, constraints imposed by the necessary length of the battery (dependent on the time available for testing) required that only the most promising tests be included in the first year's testing. Measures of anxiety, motivation, locus of control, alienation, and other factors could prove productive and some may be added later if the present battery can be shortened, or if some current measures turn out to be unimportant.

Analyses will eventually focus on the relationships between affective data and achievement, parents' attitudes, SES factors, and, of course, educational program 
type. Specifically, the analyses will attempt to determine the relative importance of various factors on achievement, and most importantly, whether or not some programs are more effective than others given certain student characteristics. In this case, "characteristic" is defined in the broadest sense, including in addition to the affective test profiles such factors as SES and parent qualities. We will also of course determine changes in affect if they occur and attempt to determine the factors that appear responsible.

\section{CHOICE OF TEST BATTERY}

In general, we define two purposes for the affective test battery. The first is to measure affective change over time, and the second is to use affective measures to identify some student characteristics. These are, of course, not necessarily independent, and are very likely to be confounded over time, i.e., affective growth may change the characteristic. Although we cannot rule out the possibility of affective growth and its determination by the kinds of tests used in the demonstration, we do believe that short-term changes in affect probably do not occur for reasons discussed above. There is some empirical evidence to support this. ${ }^{1}$

The primary purpose of the affective battery is to identify specific student characteristics that differentiate success in different types of programs. This is generally referred to as aptitude-treatment interaction. Treatment in this case refers to an educational program, or more accurately, to specific program features (such as structure).

Although studies of aptitude-treatment interaction are becoming more prevalent, ${ }^{2}$ there is still little conclusive evidence supporting any particular interaction, although much of the lack of success in isolating the effect is probably attributable to the primitive state of the art of affective measurement. For this reason the current affective measurement program must be considered in large part exploratory.

In our view, the basic criterion for a good affective test is one that differentiates success in the various education programs in terms of student characterstics where student success is defined by some school outcome measure. Matters of test reliability and the like are important, but these statistical properties of tests generally gain far more attention than does their ability to discriminate among students in terms of some criterion measure (other than the test score itself). Student success is differentially indicated by program when:

1. Test profiles (subtest scores within or between tests or both) for success or failure are substantively different among programs, or

2. Regression of affective scores against success produces slopes for the same profiles that are different among programs.

Both require high correlations between some measure of program success and affective scores.

In the first year of the voucher demonstration, several tests for each affective factor discussed above were administered. The purpose of the first year's affective

\footnotetext{
${ }^{1}$ Personal communication with Coopersmith also supports this. See also S. B. Khan, "Affective Correlates of Academic Achievement: A Longitudinal Study," Measurement and Evaluation in Guidance, Vol. 3, 1970, pp. 76-80.

${ }^{2}$ L. J. Cronbach and R. E. Snow, Final Report: Individual Differences in Learning Ability as a Function of Instructional Variables, Stanford University Press, Stanford, Calif., 1969. Also see G. H. Bracht, "Experimental Factors Related to Aptitude-Treatment Interactions," Review of Educational Research, Vol. 40, 1970, pp. 627-646.
} 
test program was to determine the usefulness (in terms of the criteria defined above) of various affective tests for future use in evaluating the voucher demonstration. It is important to remember that this first evaluation of the test program does not attempt to analyze programs, schools, or other factors-the only purpose is to select tests for future evaluations.

The affective test battery consisted of five tests administered at the request of and scored and analyzed by The Rand Corporation, and two that were administered, scored, and analyzed by the Alum Rock School District. The five tests that Rand administered are: The Coopersmith Self Esteem Inventory (Coopersmith, 1967), the Sears Self Concept Inventory (Sears, 1964), the Purdue Social Attitude Scale, the Primary Self Concept Scale (Leonetti, 1973), and the Primary Mental Abilities Test (PMA). The first two were given to a small sample of students in kindergarten through 6th grade. Rand was unable to analyze the districts' two tests because students usually did not put their ID numbers on these test papers, and it was not possible to match scores to students. These two tests, originally developed by the Cincinnati school district, were surveys of student attitudes about self and schoolone for the upper elementary grades and one for the lower.

The sample structure for each affective test turned out to be more complex than originally planned, and this had direct bearing on the kinds of analysis used on the data. This resulted primarily from the fact that teachers were allowed to not give affective tests if they so desired. Since the purpose of the first year's affective testing was to select one of two tests at each grade level, the complications and loss of information introduced by the sample structure were not serious, except that the analysis is more difficult to follow.

In very brief summary, the analysis indicated that the Coopersmith test best suits our purposes in the upper elementary (4-8) grades, and the Purdue test was slightly preferable for the lower grades. The results of the Coopersmith data indicate strong possibilities for the presence of an interaction between program (type) and student characteristic. A number of other results appeared interesting, but in view of the confounding between variables introduced by the sample structure, it is difficult (and probably unwise) to discuss them. While showing interesting results (very strong interactions of subscale score by program type), the PMA will not be used in the immediate future, primarily because it is too time consuming.

\section{REFERENCES}

Coopersmith, S., The Antecedents of Self Esteem, W. H. Freeman and Co., San Francisco, 1967.

Gordon, I. J., "Affect and Cognition," Educational Leadership, 1970, pp. 661-664.

Hernandez, N. G., "Variables Affecting Achievement on Middle School MexicanAmerican Students," Review of Educational Research, 1973, pp. 1-40.

Leonetti, R., A Primary Self-Concept Scale for Spanish-Surnamed Children, Grades K-4, Ph.D. Dissertation, New Mexico State University, Las Cruces, 1973.

Piaget, J., and B. Inhelder, The Psychology of the Child, Basic Books Inc., New York, 1969.

Sears, P. S., and V.S. Sherman, In Pursuit of Self-Esteem, Wadsworth Publishing Co., Belmont, California, 1964.

Zierkel, P. A., "Self-Concept and the Disadvantage of Ethnic Group Membership and Mixture," Review of Educational Research, 1971, pp. 211-226. 